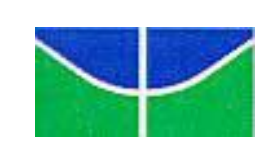

UNIVERSIDADE DE BRASÍLIA - UNB

FACULDADE DE ECONOMIA, ADMINISTRAÇÃO E CONTABILIDADE - FACE PROGRAMA DE PÓS-GRADUAÇÃO EM ADMINISTRAÇÃO

\title{
ADERÊNCIA À MUDANÇA: UM ESTUDO EMPÍRICO NO CONSELHO ADMINISTRATIVO DE DEFESA ECONÔMICA - CADE
}

MARIANE CORTAT CAMPOS MELO

BRASÍLIA - DF

2015 


\section{ADERÊNCIA À MUDANÇA: UM ESTUDO EMPÍRICO NO CONSELHO ADMINISTRATIVO DE DEFESA ECONÔMICA - CADE}

\section{MARIANE CORTAT CAMPOS MELO}

Dissertação apresentada ao Programa de PósGraduação em Administração da Universidade de Brasília (PPGA/UnB), como requisito parcial à obtenção do grau de Mestre em Administração.

Orientador: Prof. Dr. Francisco Antônio Coelho Junior

BRASÍLIA - DF 


\section{Mariane Cortat Campos Melo}

Aderência à mudança: um estudo empírico no Conselho Administrativo de Defesa Econômica CADE

Esta dissertação foi avaliada pela seguinte banca examinadora:

Professor Dr. Francisco Antônio Coelho Júnior (Presidente)
Universidade de Brasília (UnB)

Professora Dra. Catarina Cecília Odelius (Membro) Universidade de Brasília (UnB)

Professora Dra. Luciana Mourão Cerqueira e Silva (Membro) Universidade Salgado de Oliveira (UNIVERSO)

Brasília

2015 
Sinto-me feliz em perceber que tenho muitas pessoas a quem agradecer pelo apoio e contribuição na minha vida e para essa dissertação!

Em primeiro lugar, um agradecimento ENORME ao meu querido orientador, Professor Francisco. Obrigada pelo seu apoio, pela paciência, pela motivação nos momentos cruciais, pelas correções, pelo empenho no meu aprendizado e, principalmente, por acreditar no meu potencial. Eu não poderia ter tido orientador mais dedicado, paciente e incentivador do que você. Obrigada pelo papel que você desempenhou no meu amadurecimento como acadêmica nesses dois anos que passaram tão rápido!

Obrigada a minha família - minha irmã Marcella, minha mãe Rosangela e minha avó Zelinda-, que me apoiou de diferentes formas nesses dois anos de mestrado; sendo pacientes e compreensivas com as minhas limitações, apoiadoras do meu trabalho e também me confortando nos momentos mais sacrificantes dessa jornada.

Queridos amigos do mestrado, meus Outliers, obrigada pelas ideias, pelas aulas, pela discussão e crítica do meu projeto, pelas risadas e pelo apoio nos momentos difíceis. Vocês são um dos meus melhores resultados! Um agradecimento especial vai à minha querida amiga Renata, que foi minha companheira desde o início de matérias, artigos, sofrimentos, orientações conjuntas, de tardes e noites na biblioteca e coruja da madrugada nessa reta final. Teu apoio foi fundamental, te levarei para a vida! Obrigada às queridas Dani, Isadora, Beatriz, Amanda e Cárita, pela parceria de sempre! Obrigada também à querida Natasha Fogaça, referência de competência e dedicação para mim, sempre disposta a me ajudar e me incentivar. Fico muito feliz de ter te reencontrado aqui na UnB!

Obrigada aos meus amigos de longa data, que são como uma segunda família para mim; meus queridos Originais, Marilene, Camilla, meninas... vocês me acompanham a muito tempo, e essa conquista também é de vocês!

Obrigada aos colegas do Cade, que tiveram paciência comigo nesse tempo em que precisei importunar para obter dados para a minha dissertação e sempre me atenderam, seja para preencher um questionário, fazer uma entrevista ou me ouvir quando eu precisava desabafar. Cada um tem parcela essencial de contribuição nesse resultado! Obrigada especial à equipe da Assessoria de Planejamento e Projetos, e um mais 
especial ainda para Mariana Rosa, minha querida amiga e minha eterna "chefinha". O seu apoio nesses 3 anos de convivência foram fundamentais, me incentivando a entrar no mestrado, me apoiando quando meu pai faleceu em 2013, me oferecendo oportunidades de crescimento que me transformaram, me fizeram uma pessoa melhor e mais preparada para os novos desafios. Obrigada também à equipe da Coordenação-Geral de Gestão de Pessoas, meu novo lar, e a Marcio Gama, pelo apoio nessa reta final. Obrigada de coração!

Obrigada a todos os funcionários do PPGA, que nos acompanharam nessa jornada, em especial a Sonária, que sempre deu excelentes conselhos para todos os alunos e nos apoiou.

Por fim (mas não menos importante!), obrigada às professoras Catarina e Luciana, por aceitarem fazer parte da avaliação dessa dissertação e por sempre contribuírem positivamente para a qualidade desse trabalho.

Muito obrigada a todos! 


\section{SUMÁRIO}

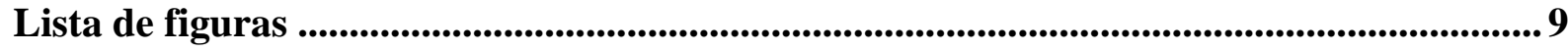

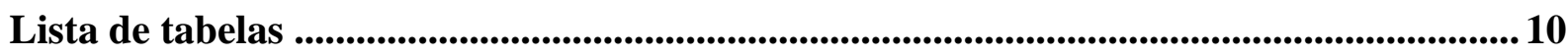

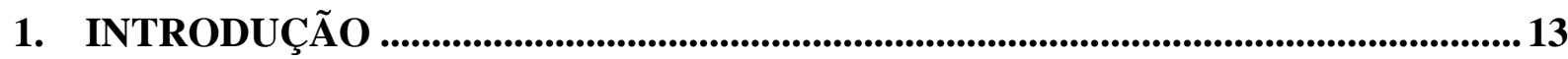

1.1. Objetivos geral e específicos .............................................................................................. 15

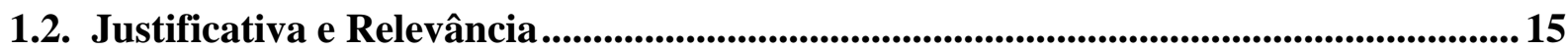

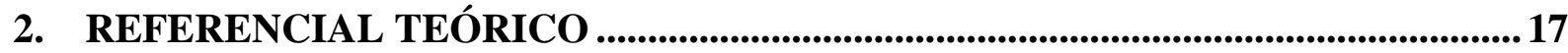

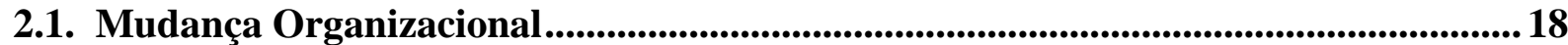

2.2. Reações frente à mudança ..................................................................................................... 23

2.3. Estrutura organizacional ............................................................................................................34

2.4. Resultado da revisão de literatura ......................................................................................39

3. MODELO TEÓRICO HIPOTETIZADO............................................................... 43

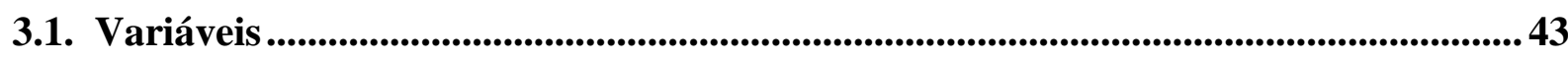

3.1.1.Variáveis explicativas/independentes ................................................................................4 44

3.1.1.1. Aderência à mudança .....................................................................................................4 44

3.1.1.2. Variáveis pessoais e profissionais...........................................................................45

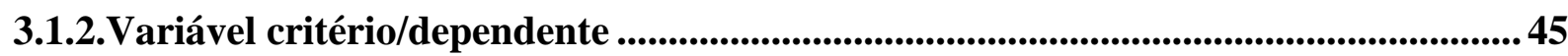

3.1.3.Variável moderadora .................................................................................................................... 46

3.2. Hipóteses de pesquisa ................................................................................................................... 46

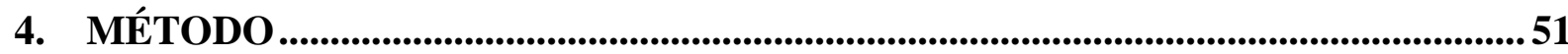

4.1. O processo de mudança organizacional no Conselho Administrativo de Defesa

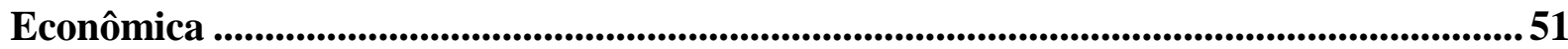

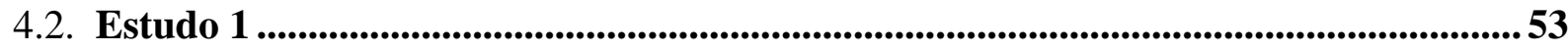

4.2.1.População e Amostra ................................................................................................................5 53

4.2.2.Procedimentos de coleta de dados..............................................................................54

4.2.3.Análise dos dados.....................................................................................................................5 55

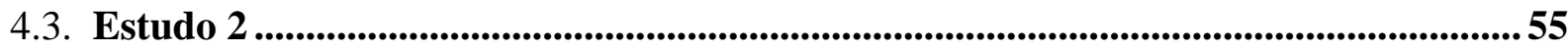

4.3.1.População e Amostra ..........................................................................................................56

4.3.2.Procedimentos de coleta de dados......................................................................................... 57

4.3.2.1. Medida de Aderência à Mudança ............................................................................5 57

4.3.2.2. Medida de Resultado percebido .................................................................................. 57 
4.3.2.3. Escala de Percepção de Componentes da Estrutura Organizacional ............. 57

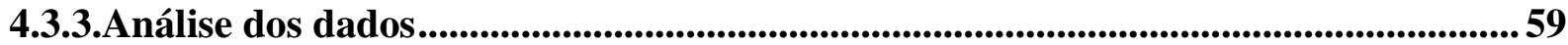

4.3.4. Caracterização da Amostra ..............................................................................62

4.4. Estudo 3 ........................................................................................................................... 66

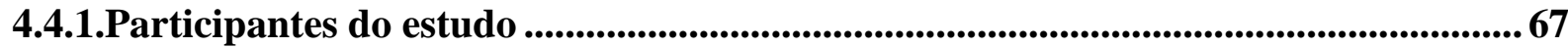

4.4.2.Procedimentos de coleta de dados ............................................................................ 67

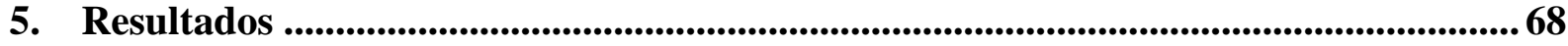

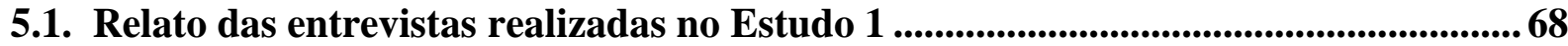

5.1.1.Mudanças percebidas e esperadas pelos participantes ............................................ 68

5.1.2.Percepção de planejamento da mudança ...................................................................... 69

5.1.3. Resultados esperados e percebidos ...................................................................................... 70

5.1.4.Fatores que facilitaram e dificultaram o processo ..................................................... 71

5.1.5.Reações verificadas......................................................................................................................... 72

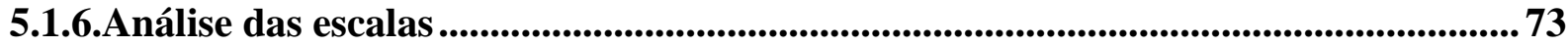

A) Escala de Aderência à Mudança ............................................................................................... 74

b) Escala de Componentes da Estrutura Organizacional ................................................. 77

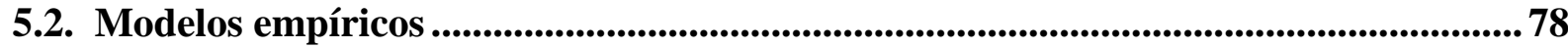

5.2.1.Modelos empíricos reduzidos ......................................................................................... 78

5.2.2. Resultado dos testes não paramétricos ......................................................................90

5.3. Resultados do Estudo 3 ..........................................................................................94

5.3.1.Mudanças percebidas e esperadas pelos participantes .................................................. 95

5.3.2.Percepção de planejamento da mudança .................................................................... 96

5.3.3.Fatores que facilitaram e dificultaram o processo ....................................................99

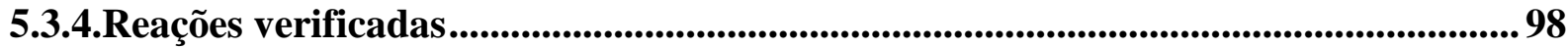

5.3.5.Percepção dos componentes da estrutura organizacional. ............................................ 99

6. Discussão dos resultados ........................................................................................................ 100

7. Considerações finais ................................................................................................................ 106

7.1. Recomendações práticas ..................................................................................... 107

7.2. Limitações .................................................................................................................................... 108

7.3. Agenda de pesquisa .................................................................................................... 109

8. REFERÊNCIAS BIBLIOGRÁFICAS .......................................................... 112 
ANEXO I - Medida de aderência à mudança .......................................................................... 119

ANEXO II - Resultados percebidos ........................................................................................ 121

ANEXO III - Escala de Percepção de Componentes de Estrutura Organizacional........ 122

ANEXO IV - Conjunto de Informações sócio-demográficas.................................................125 


\section{Lista de figuras}

Figura 1. Antecedentes, reações explícitas, e consequências da mudança organizacional. .. 28

Figura 2. Principais definições sobre reações à mudança.................................................. 33

Figura 3. Mapa conceitual sobre reações à mudança ....................................................................... 42

Figura 4. Representação gráfica do modelo teórico .............................................................. 49

Figura 5. Scree plot ............................................................................................................................ 75

Figura 6. Freqüência agregada dos resultados percebidos por participante........................... 81

Figura 7. Diferença na formação da variável "aderência à mudança" em função da participação no processo de mudança organizacional ..................................................... 92

Figura 8. Diferença na formação da variável "aderência à mudança" por ocupantes em cargos de chefia................................................................................................................................. 93 
Lista de tabelas

Tabela 1

Resumo sobre as definições de mudança organizacional.

Tabela 2

Resultados da revisão de literatura sobre a variável mudança organizacional..................... 41

Tabela 3

Resumo das variáveis demográficas da amostra.

Tabela 4

Resultados mapeados a partir do Estudo 1

Tabela 5

Análise fatorial da escala de Aderência à Mudança................................................................. 75

Tabela 6

Freqüências de resultados percebidos

Tabela 7

Regressão logística com uma variável independente.

Tabela 8

Regressão logística variáveis pessoais, profissionais e aderência à mudança.

Tabela 9

Regressão logística com testes de moderação. 86

Tabela 10

Resumo dos resultados encontrados em termos de significância de variáveis.

Tabela 11

Resultado dos testes de Mann-Whitney para a variável "aderência à mudança"

Tabela 12

Estatísticas descritivas da formação da aderência à mudança segmentada por grupos ....... 93 


\section{RESUMO}

A mudança organizacional é um tema presente nos estudos organizacionais em virtude da percepção de que vivemos em um mundo em constante transformação, criando demanda por adaptação. Um dos elementos mais investigados é a contribuição dos indivíduos para os processos de mudança organizacional, baseado na percepção de que organizações são entidades complexas e que, em última instância, são construídas pelos indivíduos que as formam. Muitas vezes, falhas são atribuídas a reações negativas das pessoas e comportamentos de resistência; essa simplificação das possíveis reações dos indivíduos à mudança, porém, esconde um mundo complexo de interações entre diversos componentes organizacionais, de processo e de atitudes positivas, ambivalentes e negativas frente à mudança. Nesse contexto, o objetivo geral definido para esse trabalho era identificar, empiricamente, a influência da aderência à mudança sobre os resultados percebidos, considerando-se o papel moderador de componentes da estrutura organizacional, no Conselho Administrativo de Defesa Econômica - Cade, executado por meio de três estudos. O Estudo 1 buscou descrever o processo de mudança pelo qual o Cade passou e criar duas escalas, uma de aderência à mudança e outra de resultados percebidos, de forma a operacionalizar as medidas para o teste empírico das relações propostas por meio do Estudo 2; o Estudo 3, de natureza qualitativa, buscou incorporar uma visão coletiva dos participantes do grupo focal conduzido. Como resultados quantitativos, foram analisados 12 modelos empíricos reduzidos e 1 modelo empírico global, que indicou que a variável aderência à mudança relacionou-se positivamente com os resultados percebidos em diversos modelos empíricos reduzidos, mas com baixo poder explicativo; o mesmo ocorreu com as relações de moderação testadas com a variável estrutura organizacional. Não foi possível tirar conclusões a partir do comportamento das variáveis pessoais e profissionais. O Estudo 3 trouxe como principais resultados o registro de reações de ambivalência à mudança e a emergência de fatores de conteúdo da mudança que podem contribuir para a formação da aderência à mudança. As principais contribuições teóricas desse trabalho são o teste empírico das relações hipotetizadas na literatura e a operacionalização de um constructo para pesquisa, de forma a avançar na consolidação teórica da área.

Palavras-chave: mudança organizacional; reações à mudança; aderência 


\section{ABSTRACT}

Organizational change is a recurrent theme in organizational studies, due to the realization that we live in a changing world, generating demand for adaptation. One of the elements most investigated is the contribution of individuals to these processes, founded on the perception that organizations are complex entities and, ultimately, are built by those who are part of it. Often, failures are indebted to negative reactions from individuals and resistance behaviors; this simplification of the possible reactions of individuals to change, however, hides a complex world of interactions among various organizational components, process and positive, ambivalent and negative attitudes towards change. In this context, the general objective set for this work was to identify empirically the influence of adherence to change with perceived results, considering the moderating role of the components of the organizational structure, in the Administrative Council for Economic Defense - CADE, executed through three studies. Study 1 described the process of change by which the Cade went through and create two scales for operacionalization of two constructs, adherence to change and perceived outcomes, in order to operationalize the measures for the empirical test of the proposed relations through the Study 2; Study 3, qualitative, sought to incorporate a collective vision of the participants of the focus group conducted. Quantitative results were analyzed in 12 reduced empirical models and 1 global empirical model, which indicated that the variable adherence to the change was related positively with the results perceived in several reduced empirical models, but with low explanatory power; the same happened in regard to the moderation test. It was not possible to reach any conclusions regarding the behavior of demographic and professional variables. Study 3 brought as main results the noticing of ambivalent and positive reactions to change and the emergence of changing the content of factors that can contribute to the formation of adherence to the change. The main theoretical contributions of this work are the empirical test of the hypothesized relationships in literature and the operationalization of the construct for research, in order to advance the theoretical consolidation of the area.

Keywords: organizational change, reactions to change, adherence to change, attitudes. 


\section{INTRODUÇÃO}

A mudança organizacional é um tema presente nos estudos organizacionais pela percepção de que vivemos em um ambiente de grandes mudanças e pela capacidade de resposta das organizações a essas contingências. Dentro do campo de estudo do Comportamento Humano nas Organizações, é um tema complexo e multidisciplinar que perpassa a administração e a psicologia organizacional, dentre outras áreas do conhecimento, com riquíssima produção teórica. Esse tema também é bastante explorado no mundo organizacional em virtude da sua relevância prática, mas nem sempre há alinhamento entre teoria e prática (Sorge \& Van Witteloostuijn, 2011).

Esse tema é multifacetado, passível de análise por diversas lentes, níveis de análise e perspectivas teóricas (Armenakis \& Bedeian, 1999) e, principalmente, construção de relações de causa e efeito entre o indivíduo, a organização e os componentes de sua estrutura e o ambiente externo. Por essa versatilidade, os estudos sobre mudança são marcados, ao mesmo tempo, pela criatividade de um campo com inúmeras relações não investigadas, e pela complexidade e dificuldade de se construir um corpo teórico e empírico mais consolidado como o observado em outras variáveis investigadas pelo $\mathrm{CO}$.

Um dos elementos que tem se sobressaído dessa abordagem é a contribuição dos indivíduos para os processos de mudança organizacional, baseado na percepção de que organizações são entidades complexas e que, em última instância, são construídas pelos indivíduos que as formam (Van de Ven \& Poole, 2005). Muitas vezes, problemas no processo de implementação ou a constatação de repercussões negativas são atribuídas a reações negativas das pessoas, a tal ponto que um dos principais conselhos para os gestores é a criação de estratégias para evitar esse processo de resistência e, consequentemente, a não realização dos resultados desejados (Ford, Ford \& D’Amelio, 2008; Hernandez \& Caldas, 2001).

A abordagem mais tradicional sobre reações dos indivíduos frente à mudança é a resistência (Hernandez \& Caldas, 2001), e é considerada corriqueiramente como a causa do fracasso dos processos de mudança implementados. Esse cenário pode gerar três consequências: (i) ignorar que as reações à mudança são complexas, e não necessariamente negativas (ii) rotular a resistência como algo sempre negativo, embora essa reação possa representar um processo 
saudável de proteção da organização e de maturação da intervenção (Hernandez \& Caldas, 2001; Piderit, 2000); e (iii) mascarar outros problemas da implementação de mudanças, uma vez que os problemas identificados são atribuídos a reações negativas dos indivíduos (Weiner, 2009).

Essa perspectiva tradicional tem sido substituída por abordagens mais contemporâneas, que reconhecem a complexidade das relações entre os indivíduos e as organizações, bem como a multiplicidade de reações dos indivíduos face à mudança (Piderit, 2000). A influência de fatores de contexto das organizações, como a autonomia decisória, sistema de comunicação, centralização das decisões, e do conteúdo da mudança também são temas relevantes para a investigação da lacuna entre os resultados esperados de uma intervenção e os efetivamente obtidos. Há proposições teóricas que oferecem soluções em como lidar com essa suposta lacuna entre o que os agentes desejam da mudança organizacional e o que os receptores desse processo compreendem e como lidar com essa questão (Van de Ven \& Sun, 2011), mas ainda há poucos estudos empíricos que procuram testar as hipóteses levantadas (Barends, Janssen, ten Have \& ten Have, 2014).

O fenômeno específico que inspirou essa dissertação foi o processo de transformação do Conselho Administrativo de Defesa Econômica (Cade), autarquia federal vinculada ao Ministério da Justiça. Em 2012, o Cade passou por um processo de reestruturação organizacional com a fusão com a Secretaria de Direito Econômico do Ministério da Justiça - SDE/MJ, que trouxe a ampliação de competências, incorporação de novos processos de trabalho e da força de trabalho da SDE, e a criação de uma nova cultura organizacional. O processo como um todo foi considerado um sucesso pela mídia brasileira e internacional, inclusive com a premiação do novo processo de análise de Atos de Concentração no $18^{\circ}$ Concurso de Inovação da Escola Nacional de Administração Pública. Ao avaliarem o processo, as lideranças apontam como principal fator explicativo do sucesso da intervenção o comprometimento dos servidores com todo o processo, o que contraria a premissa de que os indivíduos são resistentes à mudança quando confrontadas com processos profundos de transformação.

Considerando esse cenário, surge a seguinte pergunta de pesquisa: Quais relações empíricas podem ser estabelecidas entre aderência à mudança e os resultados percebidos pelos funcionários, considerando-se o papel moderador de componentes da estrutura organizacional, no Conselho Administrativo de Defesa Econômica? 


\subsection{Objetivos geral e específicos}

Com base no contexto e na pergunta de pesquisa, definiu-se como objetivo geral identificar, empiricamente, a influência da aderência à mudança sobre seus resultados percebidos, considerando-se o papel moderador de componentes da estrutura organizacional no Conselho Administrativo de Defesa Econômica.

Como objetivos específicos, tem-se:

- Construir e verificar evidências de validade de um instrumento de pesquisa sobre aderência à mudança;

- Testar, empiricamente, a relação entre a aderência à mudança e percepção dos resultados de implementação; e

- Verificar, empiricamente, a influência dos componentes da estrutura organizacional na relação entre as variáveis aderência à mudança e resultado percebido.

\subsection{Justificativa e Relevância}

A realização deste estudo justifica-se teoricamente pela percepção de que os trabalhos sobre reações a mudança encontram-se excessivamente concentrados no espectro negativo dessas reações, ainda que reconheçam a pluralidade de possíveis manifestações em indivíduos e grupos. Espera-se, portanto, contribuir para a apresentação de um outro olhar sobre reações à mudança, considerando que nem sempre o fenômeno da resistência será observado, e de que nem sempre a resistência à mudança será negativa para a organização.

Há alguns estudos na literatura que apontam para uma maior diversidade de reações à mudança (Neiva \& Paz, 2012; Avey, Wernsing \& Luthans, 2008; Vakola et al, 2013), mas esses estudos ainda são escassos e carecem de testes empíricos das relações hipotetizadas (Barends, Janssen, ten Have \& ten Have, 2014). Essa proposição baseia-se na perspectiva da psicologia positiva (Scorsolini-Comina \& Santos, 2010), que investiga a ocorrência de experiências emocionais positivas (como as atitudes relacionadas com as reações positivas à mudança). Segundo Scorsolini-Comina e Santos (2010), a psicologia positiva pretende se debruçar sobre as experiências, características pessoais e instituições positivas, que podem ser capaz não só de 
prevenir doenças físicas e mentais, mas também ensinar a desenvolver qualidades que permitam aos indivíduos e suas comunidades a florescerem.

Dessa forma, propõe-se, com essa dissertação, contribuir para a consolidação teórica na área ao procurar testar empiricamente as relações propostas pela literatura.

A contribuição organizacional desse estudo é a melhor compreensão do fenômeno de mudança organizacional do Cade, uma vez que houve um esforço de mapeamento da intervenção e dos resultados obtidos nessa intervenção específica para essa dissertaçao. Cada processo de mudança organizacional tem características únicas, e, por isso, os achados desse estudo podem contribuir para uma melhor compreensão da lógica da intervenção, por meio da comparação entre os resultados esperados e alcançados do processo de mudança narrado, e fornecer insights sobre processos futuros de mudança organizacional. Dessa forma, o trabalho irá contribuir não só para o desenvolvimento de conhecimento relacionado ao tema, mas para o fortalecimento da memória institucional da organização envolvida no estudo.

Essa dissertação está dividida em seis capítulos. O primeiro apresentou o problema que deu origem à pesquisa, seu objetivo geral e específicos. A revisão de literatura e o referencial teórico vem em seguida. O terceiro descreve os três estudos realizados, apresentando o método utilizado, delineação da amostra e os procedimentos de coleta e análise de dados para cada um deles. O quarto capítulo apresenta os resultados de cada estudo. O quinto apresenta a discussão dos resultados, e o sexto capítulo apresenta as conclusões. 


\section{REFERENCIAL TEÓRICO}

Nesse Capítulo, serão apresentados as definições de cada uma das variáveis que serão objeto do modelo teórico hipotetizado apresentado nessa dissertação. A última seção foi dedicada aos critérios que embasaram a revisão de literatura e os principais achados dessa revisão.

O referencial teórico apresentado no Capítulo 2 foi elaborado com base em uma análise de artigos que são referência para o estudo das variáveis da presente dissertação. A seguir serão apresentados os critérios de pesquisa e seleção de artigos e os resultados da revisão de literatura.

Foram realizadas buscas por artigos científicos em periódicos nacionais e internacionais. Os periódicos selecionados foram mapeados de acordo com a classificação Qualis, da CAPES para as áreas de administração e psicologia. Foram pré-selecionados os periódicos nacionais e internacionais classificados entre A1 e B2 no critério Qualis. A seguir, empreendeu-se o refinamento de quais periódicos seriam utilizados. Os principais critérios utilizados foram alinhamento do periódico com temas da Psicologia Organizacional e Estudos Organizacionais por serem as áreas mais afetas ao tema de mudança organizacional; dessa forma, foram excluídos periódicos que claramente não se alinhavam a essas linhas de pesquisa, tais como periódicos da área de psicologia clínica. Ressalta-se que, por esse recorte, há certa sobreposição dos periódicos de psicologia, uma vez que eles aparecem nas duas lista, o que exigiu cuidado na elaboração da lista.

Essa seleção foi feita com base na denominação do periódico e, em caso de dúvida, com base em sua linha editorial. Um segundo filtro aplicado foi a disponibilidade de acesso: os periódicos com acesso pago não foram contemplados. No caso dos periódicos internacionais, deu-se especial atenção aos utilizados por Oreg, Vakola e Armenakis (2011) em sua revisão de estudos empíricos quantitativos sobre atitudes frente à mudança, uma vez que, segundo os autores, esses periódicos são conhecidos por sua tradição na discussão sobre questões afetas ao tema de mudança organizacional.

Definiu-se alguns critérios de busca de artigos. O primeiro critério aplicado foi a busca por palavra chave. As palavras-chave utilizadas foram: mudança organizacional, resistência, resistência à mudança, atitudes frente à mudança, aderência, estrutura organizacional no caso dos periódicos nacionais; no caso dos periódicos internacionais, utilizaram-se as palavras-chave organizational change (e sua variante organizational change), resistance, resistance to change, 
attitudes towards change, readiness/willingness to change e organizational structure. Um segundo critério adotado foi a priorização de artigos empíricos que tratassem de reações frente à mudança, embora alguns artigos teóricos também componham a amostra desse referencial teórico, em um complemento à pesquisa empírica. Esse critério procurou garantir tanto alinhamento com o problema de pesquisa delineado nessa dissertação quanto oferecer uma forma de refinar a busca sobre mudança organizacional. Como um terceiro critério, buscou-se artigos entre os anos de 2003 e 2014, com o intuito de apresentar o estado da arte mais recente da pesquisa sobre mudança organizacional nacional e internacional. Ressalta-se que artigos considerados seminais para a temática foram incorporados à revisão de literatura, ainda que não atendam a esses critérios.

\subsection{Mudança Organizacional}

A mudança organizacional é tema recorrente dos estudiosos sobre teorias organizacionais, desde as primeiras concepções das organizações como sistemas abertos. Por seu caráter multifacetado, apresenta-se como um campo com diversos modelos teóricos e recomendações práticas (Burke, 2011) e análises em diversos níveis organizacionais (Weiner, 2009; Rafferty, Jimmieson, \& Armenakis, 2013). Neiva e Paz (2007) argumentam que se sabe muito pouco sobre mudança organizacional, e uma das dificuldades está na definição do conceito de mudança, pois são diversos os aspectos considerados - escopo, intensidade, tempo de reação, dentre outros -, além da sua tipologia (Greenwood \& Hinings, 1996; Weick \& Quinn, 1999) e conteúdo. A característica mais marcante do campo é a dispersão teórica, fruto do fato de não haver um conceito consolidado sobre mudança organizacional. Essa dispersão reflete-se na proposição de diversas relações entre variáveis, daí a multiplicidade de temas ligados ao conceito de mudança apresentados no item 2.1.

Nas raízes dos estudos sobre mudança organizacional está a interpretação das organizações como sistemas abertos (Burke, 2011; Scott, 2003) e que essa troca, guiada pelo objetivo organizacional de eficiência, levaria a uma constante adaptação e diferenciação de seus componentes internos. Hannan e Freeman (2007) teorizaram sobre dinâmicas que levam as organizações a tornarem-se semelhantes por meio de um mecanismo de seleção natural. Essa perspectiva deu origem à ecologia populacional (Hannan \& Freeman, 2007) e ao conceito de inércia organizacional (Hannan \& Freeman, 1984). A teoria institucional apresenta proposta 
semelhante, utilizando elementos do contexto institucional, tais como regras formais e informais e o contexto histórico. São exemplos dessa corrente teórica o isomorfismo institucional de Dimaggio e Powell (2007) e a busca da legitimidade como um recurso de sobrevivência importante para as organizações (Meyer \& Rowan, 1977; Suchman, 1995).

Essa diversidade reflete-se também nos níveis de análise do estudo, na relação entre teoria e método e nas consequiências para a generalização (Armenakis \& Bedeian, 1999; Lima \& Bressan, 2003; Oreg, Vakola \& Armenakis, 2011). A operacionalização desses conceitos e a investigação de suas relações com variáveis preditoras também é complexa (Van de Ven \& Sun, 2011), o que se reflete na proposição de modelos multinível, como por exemplo, o proposto por Whelan-Berry, Gordon e Hinings (2003), que buscou compreender a interação das mudanças no nível organizacional e individual. Por esse motivo, um primeiro olhar útil sobre o campo de estudo vem da análise das revisões de literatura empreendidas por diversos autores ao longo do tempo.

Armenakis e Bedeian (1999) realizaram uma revisão de literatura sobre mudança organizacional na década de 1990. Os autores identificaram uma grande diversidade conceitual e de abordagens, com quatro linhas básicas de pesquisa: (i) modelos que tratam do diagnóstico para a mudança organizacional; (ii) variáveis de contexto que levam à mudança, e as respostas das organizações; (iii) processos de gestão da mudança; e (iv) variáveis critério (resistência, comprometimento, cinismo) que moderam os resultados esperados dos processos apresentados em (iii) em termos de eficiência organizacional.

Lima e Bressan (2003) também realizaram uma revisão de literatura sobre mudança organizacional. As autoras propõem um questionamento que reflete a complexidade de definição desse fenômeno: "Quando se pode afirmar que começa e termina um processo de mudança organizacional? Tudo que as organizações fazem, desde sempre, para obtenção de maior eficiência, por exemplo, não se constitui em mudança?” (Lima \& Bressan, 2003, p. 19). Nesse sentido, há a discussão da mudança organizacional como um processo socialmente construído, com percepções diferentes entre os sujeitos dos fatos que determinam a mudança e sua duração (Balogun, 2007; Kuntz \& Gomes, 2012; Kim, Hornung \& Rousseau, 2011; Silva \& Wetzel, 2004). 
As autoras elaboraram quadro resumo com os diversos conceitos mapeados à época e identificaram algumas dimensões repetidas: intencionalidade, necessidade de congruência entre componentes, resposta a alterações no ambiente ou a demandas internas, percepção atrelada à dimensão temporal, e construção social da mudança. A Tabela 1 reproduz a categorização elaborada pelas autoras, complementados com definições de mudança organizacional de outros trabalhos utilizados na construção do referencial teórico dessa dissertação.

Tabela 1

\section{Resumo sobre as definições de mudança organizacional}

\section{Definição encontrada \\ Qualquer modificação, planejada ou não, nos componentes organizacionais formais e informais mais relevantes (pessoas, estrutura, produtos, processos e cultura); modificação que seja negativa, atinja a maioria dos membros da organização e tenha por objetivo a melhoria do desempenho organizacional em resposta às demandas internas e externas}

Toda alteração, planejada ou não, ocorrida na organização, decorrente de fatores internos e/ou externos à mesma, que traz algum impacto nos resultados e/ou nas relações entre as pessoas no trabalho

Qualquer transformação de natureza estrutural, estratégica, cultural, tenológica, humana ou outro componente, capaz de gerar impacto em partes ou no conjunto da organização

Atividades intencionais proativas e direcionadas, para obtenção das metas Robbins (1999) organizacionais

Resposta da organização às transformações que vigoram no ambiente, com o intuito de manter a congruência entre os componentes organizacionais (trabalho, pessoas, arranjo/estrutura e cultura).

Acontecimento temporal estritamente relacionado a uma lógica, ou ponto de vista individual, que possibilitem às pessoas pensarem e falarem sobre a mudança que percebem

Sequência de eventos que se desdobram durante a existência da entidade Van de Ven \& Poole (1995) organizacional e que relatam um tipo específico de mudança

Conjunto de teorias, valores, estratégias e técnicas cientificamente embasadas objetivando mudança planejada do ambiente de trabalho com o objetivo de elevar o desenvolvimento individual e o desempenho organizacional

\section{Referência}

Bressan (2001)

Bruno-Faria (2003)

Wood Jr. (2000)

Nadler et al (1994)

Ford \& Ford (1994)

Abstração de segunda ordem, ou seja, trata-se do registro de impressões sobre a Woodman(1989) relação entre variáveis dinâmicas

Alteração significativa, articulada, planejada e operacionalizada por pessoal interno ou externo à organização, que tenha o apoio e supervisão da administração superior, e atinja integradamente os componentes de cunho comportamental, estrutural, tecnológico e estratégico.
Araújo (1982)

Porras \& Robertson (1992) 


\begin{tabular}{|c|c|}
\hline Definiçãa encontrada & Referência \\
\hline $\begin{array}{l}\text { Alteração deliberada nos componentes estrutura formal, sistemas, processos ou } \\
\text { mercados, com o objetivo de alcançar um ou mais resultados organizacionais }\end{array}$ & Lines (2005) \\
\hline $\begin{array}{l}\text { Mudança revolucionária envolve sair de uma certa orientação, indo em direção à } \\
\text { transformação da organização. Mudança convergente é a sintonia fina dentro de uma } \\
\text { mesma orientação estratégica. Mudança evolucionária é lenta e gradual, enquanto } \\
\text { que a revolucionária acontece rapidamente. }\end{array}$ & Greenwood e Hinings (1996) \\
\hline $\begin{array}{l}\text { Qualquer alteração, planejada ou não, em componentes que caracterizam a } \\
\text { organização como um todo - finalidade básica, pessoas, trabalho, estrutura formal, } \\
\text { cultura, relação da organização com o ambiente -, decorrente de fatores internos e/ou } \\
\text { externos à organização, que traz alguma consequiência, positiva ou negativa, para os } \\
\text { resultados organizacionais ou para sua sobrevivência. }\end{array}$ & Neiva (2004) \\
\hline $\begin{array}{l}\text { Mudança episódica é usada para tratar de mudanças que tendem a ser infreqüente, } \\
\text { descontínua e intencional, e ocorre em períodos de desalinhamento entre a estrutura e } \\
\text { o ambiente. Mudança contínua envolve aquelas mudanças que são perenes, } \\
\text { evolutivas e cumulativas. }\end{array}$ & Weick e Quinn (1999) \\
\hline $\begin{array}{l}\text { Mudança é a reconstrução das redes de crença e hábitos de ação dos atores para a } \\
\text { acomodação de novas experiências advindas da interação. }\end{array}$ & Tsoukas e $\mathrm{Cl}$ \\
\hline
\end{tabular}

Fonte: Adaptado de Lima, S. M. V. \& Bressan, C. L. (2003).

As revisões de Armenakis e Bedeian (1999) e Lima e Bressam (2003) exemplificam a diversidade conceitual da variável e de conceitos correlatos presente na literatura. A título de exemplo, citam-se o uso da abordagem de redes sociais para compreensão de processos de mudança organizacional (Ferreira \& Armagan, 2011); a investigação do papel das lideranças em mudanças planejadas (Kotter, 1995; Oreg \& Berson, 2011; Seo et al, 2012); a interação entre componentes da estrutura e tipo de mudança (Voet, 2014); abordagens processuais da mudança (Tsoukas \& Chia, 2002; Van de Ven \& Poole, 2005); e o estudo das percepções e reações dos indivíduos (Hernandez \& Caldas, 2001; Neiva e Paz, 2007; Oreg et al, 2011; Vakola, Armenakis \& Oreg, 2013) e equipes (Guiette \& Vandenbempt, 2013).

Uma abordagem diferente da mudança organizacional é a que a percebe como um processo (Tsoukas \& Chia, 2002; Van de Ven \& Poole, 2005). Tsoukas e Chia (2002) rebatem a premissa de que a mudança seria exceção; para os autores, a constante das organizações é viver em mudança, e os momentos estáticos representam as ocasiões em que os indivíduos realinham suas crenças e percepções anteriores com a nova realidade; nesse sentido, a mudança é um fenômeno eminentemente social e processual por natureza. 
Thomas, Sargent e Hardy (2011) aplicaram o conceito de organizational becoming de Tsoukas e Chia a um processo de mudança cultural em uma empresa de tecnologia em comunicação. Os autores observaram os padrões de negociação entre os gestores da matriz e das filiais durante um workshop voltado para a discussão de implementação de nova estratégia, observando as interações de resistência e poder entre os grupos. Sob a ótica do organizational becoming, os autores defendem que a consecução de um processo de mudança passa também pela negociação entre os atores envolvidos por meio de dinâmicas cooperativas ou competitivas entre os atores, o que resulta numa definição coletiva do que é a mudança em questão, e, em tese, nenhum ator é capaz de impor seus interesses de maneira inequívoca. O padrão de poder e resistência nessas interações torna-se complexo, e a resistência à mudança pode ter um papel importante de construção da nova realidade organizacional.

As abordagens processuais da mudança e a valorização do fenômeno da percepção das mudanças abrem espaço para a participação do indivíduo e lançam luz sobre o nível micro de análise (Neiva \& Pantoja, 2011), em contraponto ao enfoque macro das abordagens como a ecologia populacional. Nesse sentido, uma definição de mudança organizacional que incorpore essa complexidade pode ser benéfica para uma compreensão mais completa do fenômeno.

Neiva (2004) propõe um conceito de mudança organizacional que incorpora alguns dos fenômenos apresentados nessa dissertação, tais como o horizonte temporal, elementos organizacionais variáveis e os resultados para os diversos níveis da organização. Desenvolvendo a definição apresentada por Lima e Bressan (2003), a autora define mudança como qualquer alteração, planejada ou não, em componentes que caracterizam a organização como um todo finalidade básica, pessoas, trabalho, estrutura formal, cultura, relação da organização com o ambiente -, decorrente de fatores internos e/ou externos à organização, que traz alguma consequência, positiva ou negativa, para os resultados organizacionais ou para sua sobrevivência" (Neiva, 2004, p. 23). É importante que essas mudanças sejam percebidas pelos sujeitos, pois a percepção é uma importante pista de que o efeito esperado foi obtido (Santos, Neiva e AndradeMelo, 2013).

Para fins de realização dessa dissertação, mudança organizacional será compreendida como definido por Neiva (2004). Justifica-se a escolha da definição proposta pela autora pela abrangência em termos de intencionalidade, fonte das mudanças e em suas consequiências. 
Em suma, os estudos sobre mudança organizacional são marcados pela diversidade conceitual e de categorias de análise; o elemento comum é a percepção de alteração em algum componente organizacional, resultado da comparação entre estados da organização de dois momentos distintos no tempo. Essa diversidade se reflete na quantidade de modelos propositivos e na definição adotada nos estudos empíricos, especialmente nos que abordam as reações dos indivíduos frente à mudança, tema explorado na próxima seção.

\subsection{Reações frente à mudança}

O estudo de reações dos indivíduos frente à mudança é uma vertente importante do campo de estudo de mudança organizacional, tanto pela importância do elemento humano no processo de mudança organizacional quanto pela proposição teórica que essas reações podem contribuir ou atrapalhar a implementação de processos de mudança organizacional (Binci, Cerruti \& Donnarumma, 2012), especialmente quando se trata de processos planejados (Oreg et all, 2011; Vakola et al, 2013). As organizações possuem divisões e grupos sociais internos que interpretam os eventos a que estão submetidos e podem expressar reações negativas, neutras ou até mesmo positivas; nesse sentido, as cognições podem influenciar na formação de afetos e comportamentos derivados da mudança no nível individual (Fugate, 2013) e de equipes (Guiette \& Vandenbempt, 2013).

Tradicionalmente, os estudos sobre resistência à mudança eram voltados aos determinantes ambientais e organizacionais, conforme ilustrado pela perspectiva da ecologia populacional e a perspectiva institucional. Gradativamente, a participação dos fatores internos de resistência, em especial as reações dos indivíduos, ganhou espaço na literatura e na prática organizacional.

Hernandez e Caldas (2001) empreenderam uma revisão sobre a literatura de resistência à mudança com um enfoque nas reações individuais. Resistência à mudança é definida como "qualquer conduta que objetiva manter o status quo em face da pressão para modificá-lo" (Zaltman e Duncan, apud Hernandez \& Caldas, 2001), e é uma das possíveis respostas à mudança. Segundo os autores, essa expressão é creditada a Kurt Lewin, que a define como a tendência de um indivíduo ou grupo de se opor a forças sociais que objetivam conduzir as organizações (definidas como um sistema em equilíbrio) a um novo patamar. 
Hernandez e Caldas argumentam que há uma série de pressupostos embasando as recomendações sobre mudança organizacional na literatura gerencial e acadêmica que são, muitas vezes, antigos e sem suporte empírico: uma vez que a mudança é um evento disruptivo e gerador de incertezas, pressupõem-se que a reação natural dos indivíduos seja negativa. Em conseqüência, os agentes de mudança não se preocupam em identificar quem poderia efetivamente resistir à mudança e, principalmente, o que causaria essa reação; a crença na resistência a tornaria uma espécie de profecia autorrealizável. Os autores defendem alguns contra pressupostos: a resistência é um fenômeno raro, e por isso, não é a resposta natural das pessoas frente a situações de mudança; não homogêneo, ou seja, varia para cada indivíduo em função de fatores pessoais e situacionais e pode se manifestar em gestores e funcionários; e pode ser útil para a organização. Além disso, a resistência pode ser a expressão de agentes de mudança que se sentiram desafiados.

Ford, Ford e D’Amelio (2008) apresentam argumentos semelhantes aos de Hernandez e Caldas (2001) em desfavor da resistência à mudança. Os agentes de mudança são apresentados como atores que lidam com situações objetivas de resistência, e não como participantes do processo, que atribuem significado aos comportamentos e comunicações dos funcionários e, por conseqüência, constroem a resistência em suas narrativas. Para os autores, a resistência deve ser percebida como o resultado da qualidade da relação entre os agentes de mudança e os funcionários, e a sua contribuição potencial para o próprio processo de mudança tem de ser considerada. Em face de eventos disruptivos, os participantes são levados a um processo de significação (sensemaking), definido como um processo ativo que inclui a extração de comportamentos e comunicações de eventos contínuos, sua interpretação e subseqüente ação sobre o resultado dessa interpretação. Para os autores, a resistência é uma função da interpretação dos agentes de mudança das verbalizações públicas dos funcionários, e não correspondem necessariamente às disposições internas - por exemplo, pode-se ter participantes com disposições internas positivas e comportamentos expressos que são enquadrados pelos agentes de mudança como resistência, e vice-versa. As reações são variadas, ainda que sejam agrupadas sob um mesmo rótulo. Thomas, Sargent, e Hardy (2011) também tratam do processo de construção de significados por meio da linguagem, e reforçam que a implementação de um processo de sucesso não deve ser percebido como uma responsabilidade do agente de mudança; em verdade, os 
autores advogam pelo fim dessa dualidade, que não representa de forma adequada a dinâmica de poder e resistência em que os agentes e os recipientes das mudanças estão imbricados.

Piderit (2000) empreendeu uma revisão sobre estudos de resistência à mudança com o objetivo de apresentar uma perspectiva mais ampla das possíveis reações a mudança. Em sua revisão, a autora apresenta o conceito de resistência à mudança como uma força em favor da manutenção do status quo, como se essa fosse a primeira (e única) reação dos componentes de uma organização ao processo de mudança; empiricamente, esse conceito tem sido estudado como um estado cognitivo, um estado emocional, e um comportamento. Para Piderit (2000), essa estrutura tripartite pode ser reintegrada em um quadro baseado no conceito de atitudes, ou seja, componentes cognitivos, afetivos e intencionais integrados.

Dessa forma, a autora propõem um modelo tripartite, e define a dimensão cognitiva como as crenças (positivas ou negativas) em relação ao objeto; a dimensão afetiva como as emoções evocadas pelo objeto; e a dimensão conativa indica a intenção de agir, em vez de indicar o comportamento efetivo. A principal vantagem apontada é a variabilidade que pode ser observada ao se utilizar um constructo atitudinal, abrindo espaço para observação de atitudes positivas, negativas ou ambivalentes. Para Piderit (2000), essa última seria a atitude frente à mudança mais comumente encontrada, constituindo o ponto de partida das atitudes do indivíduo frente à mudança. Ambivalente seria o ponto de partida.

Lines (2005) propõe uma abordagem atitudinal sobre a mudança organizacional. Segundo a autora, em ambientes que desafiam a adequação de estratégicas organizacionais, a capacidade de uma organização de conceber e implementar mudanças torna-se crucial. O sucesso da implementação é uma função direta das reações dos membros da organização; ainda assim, há um viés da literatura para as respostas negativas à mudança (Lines, 2005, p. 9). A autora oferece uma abordagem alternativa sobre atitudes frente à mudança, que permita a apreensão das diversas respostas organizacionais possíveis, de acordo com suas dimensões de força e valência, passando pelos aspectos cognitivos, afetivos e comportamentais.

Lines (2005) argumenta que o momento mais efetivo para influenciar atitudes frente à mudança organizacional acontece no início do processo, quando as atitudes estão em fase de formação. A autora define mudança organizacional como um processo de mudança deliberado nos componentes estrutura formal, sistemas, processos ou mercados com o objetivo de alcançar 
um ou mais resultados organizacionais (Lines, 2005, p. 9-10). Essas mudanças podem iniciar em qualquer nível hierárquico, ou seja, não é necessariamente uma iniciativa das lideranças da organização. Após as atitudes formadas, o seu processo de alteração é mais complexo e demorado.

Embora outros constructos semelhantes a resistência à mudança aparecem na literatura, tais como o cinismo frente à mudança (DeCelles, Tesluk \& Taxman, 2013), abordagens mais positivas ganharam força no estudo de reações à mudança (Avey, Wernsing \& Luthans, 2008; Fugate, 2013; Armstrong-Stassen \& Schlosser, 2008). Um conjunto de estudos sobre o conceito de disposição para a mudança (readiness to change) aparece na literatura, mas com conceito variado; pode significar desde um conjunto de atitudes que refletem uma avaliação do processo de mudança no nível de indivíduos (Kuntz \& Gomes, 2012) ou uma decisão compartilhada na organização de implementar uma mudança e a percepção da capacidade para fazê-lo (Weiner, 2009). Essa diversidade abre espaço para estudos multiníveis do constructo (Rafferty, Jimmieson \& Armenakis, 2013).

As contribuições teóricas de Piderit e Lines aparecem na literatura como inspiração para estudos empíricos que buscassem refletir a complexidade da formação e expressão das diversas reações à mudança - por exemplo, Oreg, Vakola e Armenakis (2011) utilizaram os conceitos de Piderit (2000) para a sistematização de sua revisão de literatura. Além disso, percebe-se que a proposição da aplicação do conceito de atitudes para os estudos foi ao encontro de diversos estudos empíricos que já utilizavam as dimensões cognitiva, afetiva e comportamental/intencional para comunicar e explicar os resultados encontrados

Oreg et al (2011) realizaram uma extensa pesquisa sobre as reações dos indivíduos à mudança na literatura organizacional. A pesquisa partiu da percepção de que a maior parte da pesquisa sobre mudança concentra-se sobre como as organizações preparam-se para a mudança, embora um dos principais determinantes de sucesso sejam as reações dos recipientes da mudança. A dispersão teórica foi uma das principais características encontradas, levando a situações em que os mesmos conceitos aparecem sob denominações diferentes, e constructos com o mesmo nome medem coisas diferentes.

Os autores pesquisaram 60 anos de produção (1948 a 2007) de estudos reações à mudança, e limitaram o escopo de sua revisão aos estudos quantitativos. Com base nos 79 artigos encontrados, mapearam o estado da arte em termos de: (i) reações explícitas à mudança, 
conceituadas como atitudes conforme utilizado por Piderit (2000), composta de elementos cognitivos, afetivos e comportamentais); (ii) antecedentes dessas reações compostos de antecedentes pré-mudança (por exemplo, características pessoais e do contexto interno) e antecedentes da mudança (conteúdo, processo, benefícios e perdas percebidos); e (iii) consequências pessoais e profissionais da mudança.

Dentre os principais achados da revisão feita por Oreg et al (2011) sobre as reações explícitas, destacam-se: (i) nem todos os estudos utilizaram os três componentes atitudinais para descrever as reações dos indivíduos, mas sim uma combinação entre eles; (ii) em termos afetivos, depreende-se que foram encontrados mais estudos com um enfoque em emoções negativas do que positivas; (iii) o componente comportamental apareceu tanto como comportamentos explícitos ou como intenções de comportamento. Em termos metodológicos, a maior parte dos estudos é transversal (a coleta de dados foi realizada em um único momento) e basearam-se em auto-relatos de fonte única.

O modelo proposto por Oreg et al (2011) está reproduzido na Figura 1. 


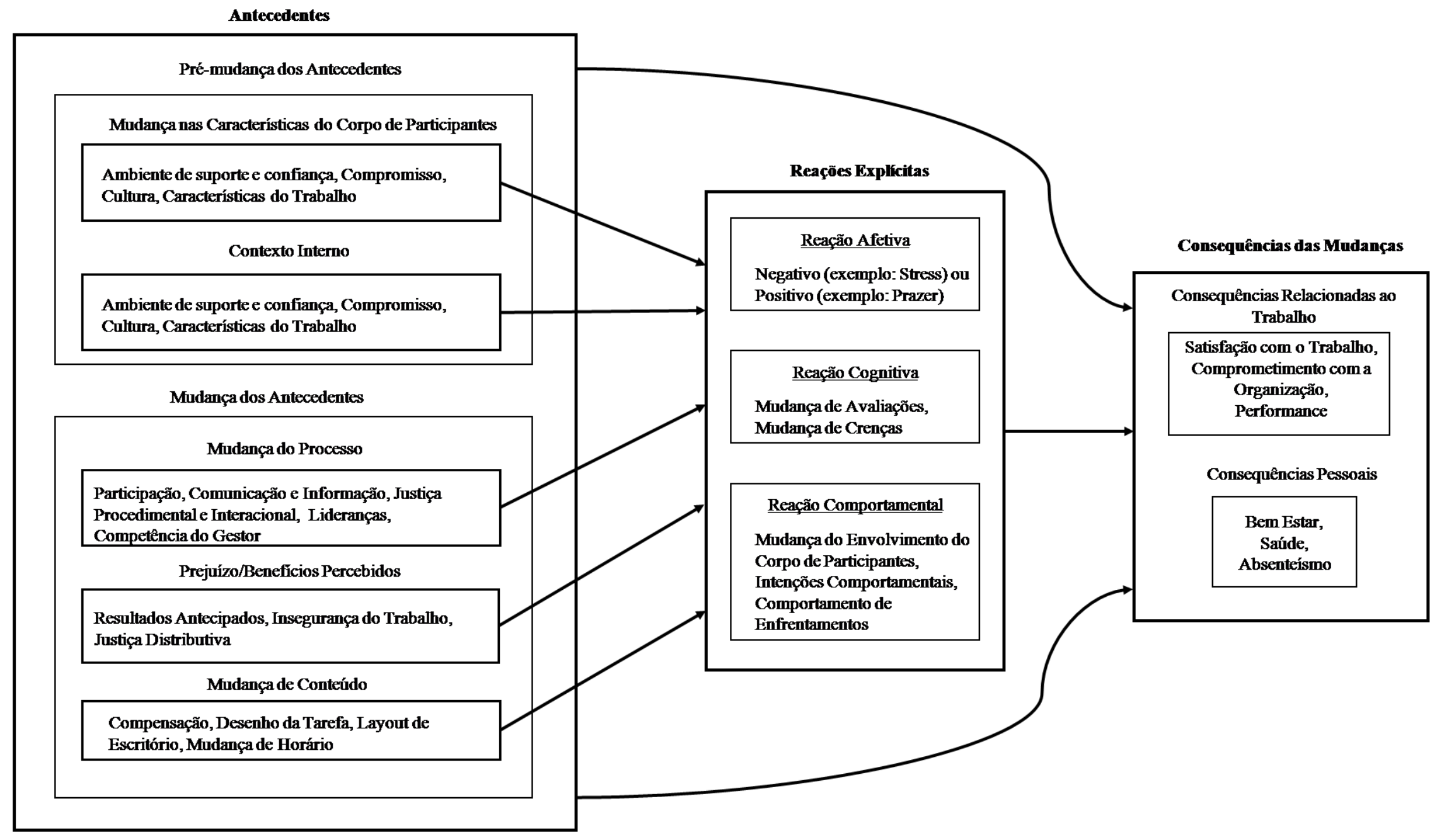

Figura 1. Antecedentes, reações explícitas, e consequências da mudança organizacional.

Fonte: Adaptado de Oreg, S., Vakola, M., \& Armenakis, A. (2011) 
A Figura 1 apresenta os principais antecedentes e consequientes encontrados nos artigos quantitativos pesquisados pelos autores. Como antecedentes, tem-se variáveis pré-mudança (variáveis do contexto interno e dos participantes do processo) e as que representam o tempo durante o processo (variáveis do processo, do conteúdo e dos benefícios percebidos). Essas variáveis influenciam a formação das atitudes frente a mudança em suas dimensões afetiva, cognitiva e comportamental/intenção de comportamento. A combinação das três dimensões citadas definirá se trata-se de atitudes de resistência (combinação negativa dos três componentes), de aderência (combinação positiva dos três componentes) ou ambivalentes (combinações mistas). Os conseqüentes apresentados pelos autores podem ser entendidos como resultados indiretos das intervenções de mudança: rotatividade, absenteísmo, performance (desempenho), comprometimento com a organização, e outros.

O reconhecimento dessa diversidade de reações permitiu que novos constructos fossem investigados, buscando compreender quais antecedentes e conseqüentes de atitudes positivas, ou comportamentos de apoio, contribuem para sucesso de mudanças organizacionais.

Bouckenooghe (2010) realizou uma revisão de literatura sobre resistência à mudança e sobre a disposição para a mudança (readiness to change), conceitos que representam $92 \%$ dos artigos conceituais mapeados pelo autor. Para o autor, a diversidade de experiências que um individuo pode ter ao passar por situações de mudança reflete-se no trabalho dos teóricos: alguns usam termos positivos, enquanto outros utilizam termos negativos. Apesar dessa diversidade, para o autor, o tema que conecta esses estudos é o conceito de atitudes, concebidas como um constructo tridimensional composto de componentes cognitivos (opinião sobre vantagens e desvantagens, utilidade, necessidade e conhecimento necessário para lidar com a mudança), afetivos (sentimentos sobre a mudança) e comportamentais/intencionais (ações já tomadas ou que serão tomadas no futuro a favor ou contra a mudança). $\mathrm{O}$ autor ressalta a predominância inicial dos aspectos cognitivos.

Como exemplo da proposição do estudo de reações positivas frente à mudança, Rafferty, Jimmieson e Armenakis (2013) revisaram a literatura sobre o conceito de readiness for change, traduzido livremente como disposição para a mudança. Os autores partem da preocupação com o sucesso de implementação de processos de mudança organizacional, e o quão críticas são as reações dos empregados frente à mudança organizacional como um dos componentes 
determinantes desse sucesso. A disposição para a mudança seria a atitude positiva frente à mudança de maior prevalência na literatura, ao lado do conceito de resistência. Os autores identificaram duas lacunas: 1) ênfase no componente cognitivo, e falta de pesquisa sobre o afetivo; e 2) não utilização de uma perspectiva multinível - os autores argumentam que, embora seja admitido por alguns pesquisadores que os esforços para mudança organizacional são processos multinível, a observação desse constructo tem permanecido essencialmente no nível do indivíduo.

A disposição para a mudança seria definida como crenças, atitudes, e intenções sobre o quanto a mudança é necessária e a capacidade da organização de implementá-las de forma bem sucedida. Os autores definem os resultados esperados da disposição para a mudança em dois níveis: no nível individual, seriam as ações dos indivíduos direcionadas ao suporte ativo de uma mudança planejada, gerando atitudes positivas, tais como satisfação e comprometimento organizacional; no nível do grupo, espera-se encontrar atitudes positivas e comportamentos prómudanças; no nível organizacional, as evidências observáveis seriam o desenvolvimento de capacidade de suporte à mudança. A disposição para a mudança no nível do grupo seria o resultado das cognições e afetos compartilhados entre os membros de uma unidade. A fonte do compartilhamento de afetos seriam os processos de comparação e contágio, ambos envolvendo o processamento de pistas individuais (auto-percepção dos comportamentos expressos) e situacionais (percepção do comportamento dos membros do grupo); o compartilhamento de crenças adviria, por exemplo, do processo de socialização. Os autores argumentam que não é adequado incluir a intenção comportamental como um dos componentes do constructo, mas não apresentaram a justificativa para tal exclusão.

Stevens (2013) também realizou uma revisão de literatura sobre a disposição para a mudança (readiness to change). Sua principal conclusão é a diversidade teórica que cerca esse constructo, pois ainda não restam claras sua definição constitutiva e operacional. Para fazer frente a esse desafio, o autor propõe a definição do constructo a partir de uma abordagem processual. Essa abordagem, segundo proposta do autor, perceberia esse constructo como transversal ao processo de mudança organizacional, podendo ser aferido em várias etapas e incorporando tanto os fatores contextuais de formação da disposição para a mudança quanto os aspectos atitudinais (cognições, afetos e intenções de comportamento) identificados na literatura pelo autor, aspectos esses que não permanecem estanques durante o processo de mudança. Esse primeiro passo 
constitui a avaliação inicial do processo de mudança - que é sempre revisto, a cada nova informação fornecida.

Outro constructo que trata de reações positivas à mudança é o comprometimento com a mudança organizacional. Meyer e Hamilton (2013) definem o constructo comprometimento com a mudança como um constructo multifacetado, com três grandes temas presentes nas definições identificadas por Meyer e Allen (1991, apud Meyer \& Hamilton, 2013): um vinculo afetivo com a organização; o custo percebido de se desvincular da organização; senso de obrigação de permanecer na organização. Com base nesses temas, Meyer e Allen propõem um modelo de comprometimento com a mudança baseado em um tripé formado pelo comprometimento afetivo (desejo de permanecer na organização), comprometimento instrumental (custos de saída percebidos) e o comprometimento normativo (obrigação de permanecer). Meyer e Hamilton defendem o comprometimento com a mudança é um comportamento que vai alem do apoio à mudança, e significa fazer o que for necessário para fazer o processo de mudança dar certo. Ainda segundo os autores, em termos de resultado, esse constructo relacionou-se positivamente com satisfação no trabalho, sucesso da implementação, participação nos programas de mudança e comprometimento com a estratégia, e relacionou-se negativamente com rotatividade decorrente de processos de mudança organizacional. Alguns antecedentes desse constructo seriam o envolvimento formal no processo (Kim, Hornung \& Rousseau, 2011), Auto-eficácia e outros fatores contextuais (Herold, Fedor \& Cadewell, 2007).

Outros exemplos de modelos propostos e estudos realizados são o estudo da relação entre mudança organizacional, atitude frente à mudança e a percepção de cumprimento de contratos psicológicos conduzidos por Smissen, Schalk e Freese (2013) e o conceito de capacidade organizacional para a mudança, definido como os fatores internos (nível organizacional e/ou individual) que permitem o desenvolvimento de uma ação no sentido de se efetuar mudança organizacional (Domingos \& Neiva, 2014).

Depreende-se da literatura apresentada que a utilização de um constructo atitudinal em estudos empíricos tem grande potencial para compreensão dos fenômenos como o de mudança organizacional, pois a mudança organizacional é influenciada pelo grau de apoio e engajamento explícito de indivíduos e grupos para sua implementação, ainda mais quando um dos resultados esperados em processos de mudança organizacional é a alteração nos comportamentos 
individuais. Além disso, o enfoque em atitudes pró-mudança reflete uma agenda de pesquisa mais recente embasada na perspectiva da psicologia positiva (Avey, Wernsing \& Luthans, 2008). A Figura 2 apresenta breve resumo dos principais constructos sobre reações à mudança mapeados.

\begin{tabular}{|c|c|c|}
\hline Constructo & Definição & Exemplo \\
\hline Resistência à mudança & $\begin{array}{l}\text { "Qualquer conduta que objetiva manter o status } \\
\text { quo em face da pressão para modificá-lo" }\end{array}$ & $\begin{array}{l}\text { Hernandez e Caldas } \\
(2001)\end{array}$ \\
\hline $\begin{array}{l}\text { Cinismo frente } \\
\text { mudança (CTC) }\end{array}$ & $\begin{array}{l}\text { É definido como pessimismo e ceticismo } \\
\text { extremo sobre a capacidade de mudança da } \\
\text { organização. Constructo multinível, em função } \\
\text { da interação entre a cultura organizacional e as } \\
\text { atitudes dos indivíduos frente à mudança. }\end{array}$ & $\begin{array}{l}\text { DeCelles, Tesluk e } \\
\text { Taxman (2013) }\end{array}$ \\
\hline Readiness to change & $\begin{array}{l}\text { Atitude positiva frente à mudança, às vezes com } \\
\text { predomínio de cada uma das dimensões } \\
\text { atitudinais; constructo composto de fatores } \\
\text { contextuais e de atitudes frente à mudança }\end{array}$ & $\begin{array}{l}\text { Rafferty, Jimmieson e } \\
\text { Armenakis (2013), } \\
\text { Bouckenooghe (2010) } \\
\text { Stevens (2013), }\end{array}$ \\
\hline $\begin{array}{l}\text { Capacidade } \\
\text { organizacional para a } \\
\text { mudança }\end{array}$ & $\begin{array}{l}\text { Fatores internos (nível organizacional e/ou } \\
\text { individual) que permitem o desenvolvimento de } \\
\text { uma ação no sentido de se efetuar mudança } \\
\text { organizacional. O constructo é formado por oito } \\
\text { fatores: (i) o fluxo de informação abrangente, } \\
\text { rápido e preciso dentro da organização; (ii) a } \\
\text { existência de uma estratégia de atuação } \\
\text { organizacional baseada na análise do ambiente } \\
\text { externo; (iii) a existência de coalizões } \\
\text { organizacionais apoiadoras da mudança; (iv) a } \\
\text { existência de turbulência no ambiente externo; } \\
\text { (v) a presença de autonomia de unidades e } \\
\text { pessoas na organização; (vi) a preponderância do } \\
\text { trabalho em grupo, envolvendo pessoas e } \\
\text { unidades; (vii) manifestação de direção, } \\
\text { flexibilidade e (viii) confiança na atuação } \\
\text { gerencial. A burocracia e o continuísmo no } \\
\text { funcionamento organizacional foram } \\
\text { considerados como fatores que restringem a }\end{array}$ & $\begin{array}{l}\text { Domingos \& Neiva } \\
(2014)\end{array}$ \\
\hline
\end{tabular}




\begin{tabular}{|c|c|c|}
\hline Constructo & Definição & Exemplo \\
\hline & introdução de mudanças na organização. & \\
\hline $\begin{array}{l}\text { Comprometimento com } \\
\text { a mudança } \\
\text { organizacional }\end{array}$ & $\begin{array}{l}\text { Constructo atitudinal composto de um vinculo } \\
\text { afetivo com a organização; o custo percebido de } \\
\text { se desvincular da organização; senso de } \\
\text { obrigação de permanecer na organização. }\end{array}$ & $\begin{array}{l}\text { Meyer e Hamilton } \\
(2013)\end{array}$ \\
\hline
\end{tabular}

Figura 2. Principais definições sobre reações à mudança.

Fonte: Elaborada pela autora

Rodrigues, Assmar e Jablonski (2009) definem atitudes como uma organização duradoura de crenças e cognições em geral, dotada de carga afetiva pró ou contra um objeto social definido, que predispõe a uma ação coerente com as cognições e afetos relativos a este objeto (Rodrigues et al, 2009, p. 81). Os autores defendem que o estudo do conceito de atitude na psicologia social é importante por três motivos: (i) constituem bons preditores de comportamentos; (ii) ajuda na formação de uma ideia mais estável da realidade; e (iii) elas são a base de uma série de situações sociais importantes para o indivíduo.

Rodrigues et al (2009) apontam que situações que alterem cognições, afetos ou comportamentos, pode resultar em mudanças nas atitudes do indivíduo frente a um determinado objeto pela necessidade de congruência entre as dimensões das atitudes, e que mudança de atitudes envolve a oferta de estímulos e reforço. Alguns fatores podem influenciar na mudança de atitudes, tais como a forma como as informações são apresentadas (ordem da apresentação dos argumentos, apresentação ou omissão da conclusão, comunicação uni ou bilateral, natureza emocional ou racional da comunicação), quantidade da mudança tentada, credibilidade do comunicador e características pessoais e sociais da audiência. Ressalta-se que há uma tendência de reorganização afetiva e cognitiva para garantir a congruência com um comportamento (ou intenção de comportamento, no caso de atitudes mensuradas frente a um processo de mudança a ser iniciado) exibido por necessidade.

Dessa definição, percebe-se que a verificação de quais atitudes os indivíduos possuem frente a mudança pode ser uma informação valiosa tanto para tentar antecipar os resultados do processo quanto para traçar estratégias que potencializem as respostas comportamentais positivas. A investigação da relação entre as atitudes dos indivíduos frente à mudança e os resultados e 
consequências da mudança é essencial para a testagem das proposições teóricas dos diversos modelos e para o avanço do campo de estudo das mudanças organizacionais.

Além disso, é importante notar a mudança de foco na literatura sobre reações à mudança da resistência à mudança para atitudes positivas. Essa mudança pode ser resultado (i) da percepção da complexidade das reações individuais nessas situações e (ii) da adoção de um conceito processual de mudança organizacional, que enfatiza seu caráter cotidiano e, por isso, não seria um evento tão disruptivo. Para que as relações causais entre atitudes e consequências/resultados da mudança façam sentido, é necessário haver alinhamento entre a perspectiva positiva/negativa das atitudes e o sucesso/fracasso das mudanças implementadas.

Para fins desse trabalho, será adotada uma perspectiva positiva das atitudes dos indivíduos frente à mudança. Essa perspectiva baseia-se na definições apresentadas por Lines (2005) e Rodrigues, Assmar e Jablonski (2009). Outros exemplos podem ser encontrados em outros trabalhos, tais como Bouckenooghe (2010) e Rafferty, Jimmieson e Armenakis (2013).

\subsection{Estrutura organizacional}

Os componentes da estrutura organizacional aparecem como variável importante nos estudos organizacionais, uma vez que a estrutura perpassa diversos processos organizacionais. Em última instancia, os componentes da estrutura dão forma ao que se entende por organização.

Estrutura Organizacional representa, segundo Loiola, Bastos, Queiroz e Silva (2011), uma cadeia relativamente estável de ligação entre as pessoas e o trabalho que constituem a organização, e é materializada no organograma da organização. Esse organograma, por sua vez, define a divisão de trabalho e da autoridade e o sistema de comunicação correlatos.

Mintzberg, segundo Loiola et al (2011) define a estrutura organizacional como a soma total das maneiras pelas quais o trabalho é dividido em tarefas distintas e como é feita a coordenação dessas tarefas. Essa coordenação pode ser executada por meio do ajuste mútuo, supervisão direta, padronização dos processos de trabalho, de saídas e de habilidades. As organizações possuem 5 estruturas para Mintzberg: o núcleo operacional, cuja função básica é processar o fluxo de entradas e saídas da organização e fornecer suporte aos outros elementos; a cúpula estratégica, responsável por fazer cumprir a missão e dar respostas ao público da 
organização; a linha intermediária, que liga a cúpula ao núcleo operacional; a tecnoestrutura, cujas funções são treinar os indivíduos, planejar e alterar o fluxo de trabalho, promover a padronização e analisar e propor mudanças; e a assessoria de apoio, que executa o trabalho fora do núcleo operacional.

Scott (2003) aponta como principais elementos constituintes das organizações a estrutura social, os participantes, as metas e a estrutura técnica. Esses elementos existem dentro de um ambiente organizacional, que influencia e é influenciado por eles.

Estrutura social é definida como aspectos regulares, padronizados, das relações entre os indivíduos. Essa estrutura é composta pela estrutura normativa, composta por valores regras e papéis definidos; pela estrutura cultural-cognitiva, que representam as crenças compartilhadas entre os participantes; e pela estrutura comportamental, que enfoca o comportamento real dos indivíduos. Esses três componentes interagem entre si, mas não são totalmente dependentes uns dos outros.

Scott conceitua os participantes como aqueles indivíduos que, em troca de uma série de incentivos, contribuem para a organização. São elementos desse componente as variáveis pessoais e profissionais, que exercem influência sobre a forma como os outros elementos da estrutura se manifestam.

As metas, segundo Scott, são um componente controverso das organizações, pois sua definição é complexa. De forma tentativa, o autor define meta como objetivos desejados, que os participantes buscam atingir por meio de sua atividade.

Estrutura técnica, ou tecnologia, envolve o processo transformador que toda a organização exerce sobre seus insumos. Inclui os processos de trabalho e a tecnologia propriamente dita.

Os componentes da estrutura compõe tradicionalmente os estudos sobre mudança organizacional como ponto que é alterado por alguma intervenção, em especial sobre a estrutura formal da organização (Hannan, Pólos \& Carroll, 2003), ou como fatores contextuais, tais como comunicação durante o processo (Thomas, Sargent \& Hardy, 2011) e autonomia dos grupos (Domingos \& Neiva, 2014; Kim, Hornung \& Rousseau, 2011). 
Rafferty e Restubog (2010) estudaram empiricamente o papel da comunicação formal (palestras formais) e informal (interação entre gerentes e funcionários) durante a mudança mensurada como a percepção do empregado sobre a qualidade da informação durante a mudança - sobre o comprometimento afetivo (desejo de dar suporte com base na crença de seus benefícios), que influenciaria tanto a satisfação no trabalho quanto a intenção de sair (utilizados como proxy para a mensuração de reações à mudança) e impactariam a rotatividade (um dos resultados desse processo). O papel de experiências passadas com outras mudanças na formação das expectativas sobre a mudança em curso também foi considerado: experiências negativas gerariam expectativas negativas, influenciariam a formação do comprometimento afetivo (atitude) e, conseqüente, os comportamentos de apoio/comprometimento durante o processo de mudança. Os autores encontram as seguintes relações: (i) a percepção de que a informação transmitida foi de qualidade relacionou-se positivamente com o comprometimento afetivo e negativamente com o nível de ansiedade aferido; (ii) a ocorrência de experiências negativas anteriores relacionou-se negativamente com comprometimento afetivo; $\mathrm{e}$ (iii) $\mathrm{o}$ comprometimento afetivo relacionou-se positivamente com a satisfação no trabalho e negativamente com a intenção de sair.

Domingos e Neiva (2014) definem capacidade organizacional para a mudança, definido como os fatores internos (nível organizacional e/ou individual) que permitem o desenvolvimento de uma ação no sentido de se efetuar mudança organizacional. A capacidade organizacional para mudança envolve a presença de oito fatores preponderantes: o fluxo de informação abrangente, rápido e preciso dentro da organização; a existência de uma estratégia de atuação organizacional baseada na análise do ambiente externo; a existência de coalizões organizacionais apoiadoras da mudança; a existência de turbulência no ambiente externo; a presença de autonomia de unidades e pessoas na organização; a preponderância do trabalho em grupo, envolvendo pessoas e unidades; manifestação de direção, flexibilidade e confiança na atuação gerencial. A burocracia e o continuísmo no funcionamento organizacional foram considerados como fatores que restringem a introdução de mudanças na organização.

Na revisão de literatura sobre estrutura nos artigos sobre mudança organizacional e reações, a estrutura organizacional aparece de como variável moderadora entre o tipo de mudança implementada e o tipo de liderança mais eficaz, que é o de Voet (2014). O autor debruçou-se sobre o efeito moderador da estrutura organizacional na relação entre o processo de mudança e a 
disposição para a mudança. A estrutura organizacional burocrática foi definida em termos da dimensões de centralização - grau em que os membros participam do processo decisório -, formalização - grau em que as atividades organizacionais manifestam-se em documentos escritos sobre a descrição das atividades, regulamentos e manuais -, e o apego excessivo a normas, ou red tape, definida como uma disfunção advinda do excesso de formalização.

Para testar essa hipótese, o autor realizou um estudo quantitativo em uma organização pública holandesa resultante da fusão de duas outras organizações. O autor aponta que as unidades da nova organização perceberam a mudança de maneira diversa: algumas a perceberam como processos planejados, com um programa claro, enquanto que, para outros departamentos, o processo deu-se de forma gradual e emergente. Dessa forma, Voet (2014) agrupou os respondentes em função do grau de burocratização da estrutura organizacional. Os resultados indicam que, em unidades com estruturas mais burocratizadas, intervenções planejadas tendem a relacionar-se positivamente com a disposição individual à mudança.

Greenwood e Hinings (1996) abordam o papel da estrutura do contexto institucional, definida em termos do grau de acoplamento dos setores organizacionais. O alto grau de acoplamento traduz-se na existência de templates organizacionais legitimados e na existência de mecanismos altamente articulados (profissões, normas regulatórias, instituições como o Estado) que garantam sua replicação em um mesmo campo institucional. Para os autores, quanto mais fortemente acopladas as organizações forem, mais incomum será a mudança radical (entendida como a alteração na orientação organizacional que produz verdadeira transformação) e, no caso de seu acontecimento, ela será revolucionária (entendida como uma alteração rápida e profunda da organização). Alguns elementos análogos ao conceito de estrutura informal - rotinas organizacionais, valores, interesses, dinâmicas de poder - são incorporados ao modelo que os autores chamam de dinâmica interna.

Neiva (2004) aponta a estrutura organizacional como uma das características organizacionais que afetam a mudança organizacional. Com base na revisão de literatura realizada para sua tese, a autora define estrutura organizacional como a forma como que o trabalho é coordenado, dividido e executado na organização, tanto forma e unidade a setores. Inclui centralização e descentralização da tomada de decisão, diferenciação vertical (número de 
níveis hierárquicos), formalização e padronização de procedimentos, especialização de funções, trabalho em equipe (Neiva, 2004, p. 77).

Pode-se depreender que a estrutura organizacional formal e informal contextualiza as interações entre indivíduos e grupos nos processos de mudança organizacional - por exemplo, no grau em que os participantes são inseridos no processo e no papel que o contexto institucional interno exerce sobre a dinâmica mudança/resistência (Greenwood e Hinings, 1996). Além disso, a própria estrutura formal pode passar por um processo de mudança organizacional, cujo reflexo se dará tanto no sistema de responsabilidades quanto na definição e distribuição de tarefas.

Oliveira (2011) define a estrutura organizacional como o conjunto formado pela especificação das responsabilidades dos níveis hierárquicos, pela distribuição de autoridade, pelo sistema de comunicação e pelas decisões das unidades organizacionais.

Os sistemas de responsabilidade é constituído pela amplitude administrativa (ou de controle), e é composta pela departamentalização (agrupamento de atividades homogêneas/relacionadas entre si), pelo sistema de atribuições (estabelecimento de competências para as unidades) e relações de linha e assessoria. O conceito que permeia esse sistema é o de especialização.

O sistema de autoridade lida com as relações formais e informais de hierarquia na organização. A autoridade formal, via de regra, é vinculada à estrutura hierárquica da empresa, enquanto que a autoridade informal advém das relações informais da empresa. Em um paralelo com Scott (2003), a autoridade informal é fruto das relações sociais entre as pessoas, enquanto que a autoridade formal pode derivar, por exemplo, do componente normativo.

O sistema de comunicação representa o fluxo de informação dentro da organização e que permitem que a organização funcione de forma efetiva. A comunicação pode funcionar por canais formais e informais. No caso de processos de mudança, os mecanismos informais de comunicação podem ter grande impacto sobre as reações dos indivíduos frente à mudança, pois interagem diretamente com o componente social das organizações definido por Scott (2003).

O sistema de decisões diz respeito ao grau de autonomia na tomada de decisões, identificando responsáveis e metodologia que deve ser adotada (Bertussi, 2012). 


\subsection{Resultado da revisão de literatura}

A primeira busca retornou 280 artigos. Os critérios para elaboração do referencial teórico foram aplicados novamente; ao final, foram mapeados 104 artigos ao todo, sendo 43 nacionais e 61 internacionais. Desses artigos, 26 trataram especificamente sobre mudança organizacional.

Com relação a natureza do estudo, 22 foram artigos teóricos. Com relação à natureza da pesquisa, dos 82 artigos empíricos mapeados, 53 são qualitativos, 22 são quantitativos e 7 utilizaram as duas técnicas de análise de dados. Com relação ao desenho de pesquisa, 19 artigos são longitudinais, ou seja, realizaram a coleta de dados em dois momentos.

Uma primeira característica do campo de estudo sobre mudança organizacional é a diversidade teórica, especialmente na definição do conceito de mudança organizacional. Há uma grande diversidade de definições; como exemplo, cita-se o elemento organizacional que sofre a alteração (estrutura, estratégia, processo de trabalho e comportamento do indivíduo, por exemplo), o processo da mudança, a comparação entre momentos da organização em períodos específicos, no tipo de mudança (planejada versus emergente e incremental versus radical, por exemplo), nos efeitos (positivos ou negativos). Há grande interesse no estudo da relação entre mudança organizacional e a implementação das tecnologias da comunicação e informação (Barret, Grant \& Wailes, 2006).

De forma geral, as definições de mudança referem-se a constatação de alguma alteração em algum elemento organizacional por meio da comparação entre dois momentos específicos; porém, abordagens processuais de mudança tem ganhado proeminência (Tsoukas \& Chia, 2002), e podem significar uma alteração ontológica e epistemológica. Alguns conceitos correlatos identificados foram: aprendizagem (Neiva \& Pantoja, 2011; Dobrev, Kim \& Carroll, 2003) e desaprendizagem (Tsang \& Zahra, 2008), cultura, valores, identidade (Beech \& Johson, 2005), inovação, liderança (Voet, 2013), entre outros. Um tema correlato é o papel das políticas de gestão de pessoas na implementação de mudanças organizacionais (Hertog, Iterson \& Mari, 2010).

Essa diversidade se reflete no nível de análise: os níveis macro (campo organizacional) e meso (organização) foram predominantes; contemporaneamente, o enfoque no indivíduo e grupos tem sobressaído, em função da percepção de que mudanças são desenhadas e implementadas por 
pessoas, que não existem isoladas de seu contexto (Guiette \& Vandenbempt, 2013). Vem ganhando espaço na agenda a proposição de teoria multinível, embasado na premissa de que fenômenos de mudança, ainda que concentrado sobre um componente organizacional estratégia, por exemplo - reverbera em componentes de outros níveis organizacionais (WhelanBerry, Gordon \& Hinings, 2003; Herold \& Fedor, 2007; Seo et al, 2012; Oreg \& Berson, 2011)

Sobre o lócus de pesquisa, foram estudadas tanto organizações públicas quanto privadas. Com relação ao tipo de organização estudada, 15 analisaram organizações públicas, 21 analisaram organizações privadas e, em 68 casos não foi possível identificar a natureza da organização (ou organizações) pesquisadas. Em termos de setores estudados, sobressai-se o setor de Tecnologia da Informação, especialmente tratando de análise de situações de implementação de um sistema informatizado. Essa ênfase pode estar conectada com o número de processos planejados de mudança que envolve a automatização de processos, implementação de sistemas de planejamento e monitoramento, entre outros. Em termos geográficos, a maior parte da produção concentra-se nos Estados Unidos e Europa, mas tem surgido estudos sobre organizações na Ásia, o que poderia trazer abordagens diferentes sobre o que é mudança organizacional.

Há uma predominância de abordagens funcionalistas (especialmente nos estudos quantitativos). Sobre a metodologia, há grande ênfase em métodos qualitativos, em especial entrevistas estruturas e semi-estruturadas, embora algumas abordagens utilizem grupo focal, observação participante e diários de bordo. Os estudos empíricos quantitativos dedicam-se, de forma geral, a mensurar as reações frente à mudança, seus antecedentes pessoais e organizacionais e as consequências pessoais e organizacionais da mudança. Estudos sobre o resultado de implementação, definido em termos de sucesso e fracasso, são menos frequente e marcadamente qualitativo, embora haja forte ênfase teórica na conexão entre reações individuais positivas/negativas e o sucesso/fracasso das intervenções.

A Tabela 2 apresenta o resumo dos resultados da revisão de literatura sobre a variável mudança organizacional. 
Tabela 2

\section{Resultados da revisão de literatura sobre a variável mudança organizacional}

\begin{tabular}{l|l|}
\hline Temas correlatos & $\begin{array}{l}\text { Aprendizagem e desaprendizagem, cultura, valores, identidade, conhecimento (e } \\
\text { gestão do conhecimento), inovação, liderança, desempenho individual e } \\
\text { organizacional. }\end{array}$ \\
$\begin{array}{l}\text { Níveis de análise e e } \\
\text { unidades de análise } \\
\text { Macro (campo organizacional/indústria), meso (organização/componentes } \\
\text { organizacionais) e micro (indivíduos e grupos), em um processo recente de } \\
\text { diversificação. Mais recentemente, há predomínio das perspectivas micro. }\end{array}$ \\
$\begin{array}{l}\text { Tipo de organização } \\
\text { Públicas e privadas. } \\
\text { Estudo empírico }\end{array}$ \\
$\begin{array}{l}\text { Os qualitativos predominam; abordagens quantitativas são mais aplicadas em } \\
\text { estudos sobre reações à mudança. } \\
\text { mapeados }\end{array}$ \\
$\begin{array}{l}\text { Conseqüências pessoais e organizacionais (rotatividade, satisfação) e resultados de } \\
\text { mudança (sucesso versus fracasso), satisfação no trabalho, cidadania } \\
\text { grganizacional } \\
\text { geográfica }\end{array}$
\end{tabular}

Fonte: Elaborada pela autora

A revisão de literatura sobre reações à mudança evidencia polarização entre reações negativas - abordagem mais tradicional -, reunidas sob o rótulo de Resistência à Mudança, e reações positivas. Essa última tendência é mais recente, e advém da defesa de que as reações dos indivíduos são mais complexas do que o constructo resistência à mudança (Lines, 2005).

A principal unidade de análise é o indivíduo, o que marca uma alteração no nível de análise tradicional, conforme notam Neiva e Pantoja (2011). O enfoque predominante é o cognitivo (Guiette \& Vandenbempt, 2013), ou seja, os estudos empíricos concentram-se sobre as crenças sobre mudança e percepção sobre o que muda. Elementos afetivos tem sido incorporados à análise, muitas vezes em conjunto com os aspectos cognitivos. Componentes comportamentais (ou intencionais) aparecerem mais raramente nos estudos analisados até o momento. Há grande número de estudos qualitativos. Os estudos empíricos, especialmente os quantitativos, sobre reações à mudança, têm utilizado o constructo de atitudes para conceituá-las e analisá-las. Uma possível explicação para essa ênfase baseia-se em dois pilares: (i) o constructo atitude, em suas raízes da psicologia social, são bons preditores de comportamentos, um dos principais alvos de processos de mudança; e (ii) a literatura se utiliza de dimensões do constructo para teorizar sobre 
as relações entre antecedentes (conteúdo e processo da mudança, percepção de justiça, comunicação, perspectivas de benefícios e perdas) e conseqüentes (rotatividade, absenteísmo, desempenho). A Figura 3 apresenta o mapa conceitual.

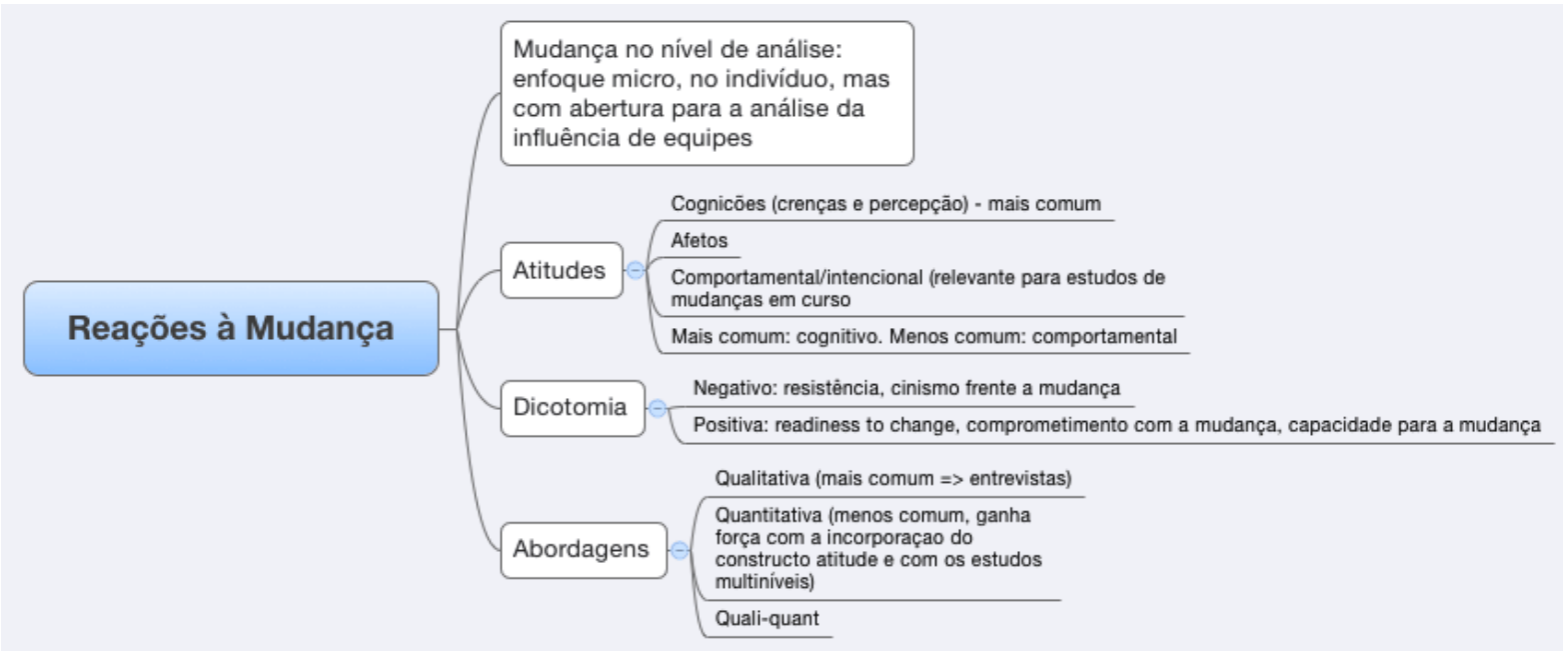

Figura 3. Mapa conceitual sobre reações à mudança

Fonte: Elaborado pela autora

Em suma, percebe-se que a principal característica do campo de estudo sobre mudança organizacional é a dispersão teórica, que também se traduz na diversidade de modelos teóricos e de estudos empíricos exploratórios. Essa característica é, ao mesmo tempo, uma fortaleza e uma fraqueza: por ser um campo em formação, há bastante espaço para inovação, mas pode-se incorrer na utilização de constructos inapropriados ao que se deseja estudar empiricamente, justamente pela diversidade teórica. Essa diversidade, inicialmente, não era tão presente no campo de estudos sobre reações pela predominância do enfoque sobre resistência à mudança. Esse cenário, porém, tem mudado, com o reconhecimento de que essas reações são mais complexas, e que variáveis de diferentes níveis organizacionais interagem umas com as outras.

A seção 2.1 teve como objetivo apresentar os principais achados da revisão de literatura. O Capítulo 3 introduzirá o modelo teórico hipotetizado, criado com base no referencial teórico apresentado neste Capítulo. 


\section{MODELO TEÓRICO HIPOTETIZADO}

Esse estudo parte de algumas premissas centrais apresentada na literatura sobre reações dos indivíduos frente à mudança e sua influência sobre os resultados obtidos de um processo planejado de intervenção.

A primeira delas é que a predisposição de indivíduos e grupos produz efeito sobre os resultados obtidos em sua implementação, ou seja, reações positivas contribuem para uma implementação mais bem-sucedida - as organizações conseguem responder a alterações bruscas em seus contextos interno e externo, ou as medidas planejadas são efetivadas e delas surgem os resultados esperados, no caso de mudanças planejadas -, enquanto reações negativas teriam o efeito oposto (Jimmieson, 2008; Avey, Wernsing \& Luthans, 2008).

A segunda premissa é que as reações dos indivíduos são plurais, podendo configurar-se em positivas, neutras e negativas, ou seja, não se pode definir a priori a disposição individual ou coletiva como essencialmente negativa. Além disso, constructos atitudinais são bons representantes para se investigar essas reações à mudança (Piderit, 2000; Lines, 2005; Bouckenooghe, 2010), pois são boas preditores de comportamentos individuais (Rodrigues, Assmar \& Jablonski, 2009).

A terceira premissa é que os componentes da estrutura organizacional podem exercer influência moderadora na relação entre atitudes frente à mudança e o grau de sucesso em sua implementação. Um mesmo processo de mudança organizacional pode gerar diferentes percepções nos indivíduos/unidades de uma mesma organização em decorrência das características da estrutura organizacional (Voet, 2014).

\subsection{Variáveis}

A seguir, serão apresentadas as definições constitutivas e operacionais das variáveis presentes nesse trabalho. O item 3.1.1 apresenta as variáveis independentes do modelo teórico proposto, o item 3.1.2 apresenta a variável dependente do estudo, e o item 3.1.3 apresenta a variável moderadora proposta.

As definições constitutivas foram adaptadas da literatura, e as operacionais foram elaboradas: (i) com base na escala de componentes da estrutura organizacional, no caso da variável estrutura organizacional; (ii) inspiradas em escalas existentes sobre reações positivas 
frente à mudança, e na literatura de atitudes referenciada nessa dissertação, no caso da variável aderência à mudança; e (iii) em entrevistas a serem realizadas na organização com as lideranças responsáveis pelo desenho das mudanças planejadas e seus resultados esperados, no caso da variável resultado percebidos.

\subsubsection{Variáveis explicativas/independentes}

A seguir, serão apresentadas as variáveis explicativas que integraram o modelo proposto nessa dissertação. O item 3.1.1.1 apresentou a definição da variável "aderência à mudança" e o item 3.1.1.2 introduziu as variáveis pessoais e profissionais.

\subsubsection{Aderência à mudança}

O ponto de partida desse constructo é uma abordagem processual da mudança organizacional e das organizações, conforme o conceito de organizational becoming apresentado por Tsoukas e Chia (2002). A mudança organizacional é comum e, por isso, não se pode perceber a resistência à mudança como a primeira reação dos indivíduos a percepção de mudanças (Hernandez \& Caldas, 2001).

A aderência é uma resposta atitudinal à mudança e, como tal, é formada por componentes cognitivos, afetivos e comportamentais. A dimensão da percepção é parte inerente desse constructo pelo fato de que a realidade organizacional é socialmente construída, pela interação social entre os indivíduos e seus ambientes quanto pela importância da percepção dos diversos agregados sociais sobre o que é esperado em termos comportamentais e, portanto, carrega todas as implicações metodológicas apresentadas na seção 2. Por fim, é importante ressaltar que esse constructo é baseado em teoria multinível pela natureza do fenômeno estudado, pela interação entre variáveis de diversos níveis e pela possibilidade de análise de diferenças e semelhanças entre os agregados sociais que formam as organizações.

Definição constitutiva: representa atitude pró-mudança frente, ou seja, é a predominância de cognições, afetos e intenção de comportamentos positivos frente a uma situação de mudança organizacional percebida e pode gerar comprometimento com o sucesso dessa mudança. Essa definição é baseada na proposição de Lines (2005) e conforme a definição de atitudes apresentada por Rodrigues, Assmar e Jablonski (2009). As dimensões identificadas para a variável são: a cognitiva, que corresponde as percepções dos indivíduos sobre a necessidade da mudança e sobre os processos de informação; a afetiva, que representa as emoções suscitadas por 
um fenômeno específico de mudança organizacional, consistindo em um processo avaliativo; e a comportamental, que representa a intenção de agir e, via de regra, é consistente com as outras duas dimensões.

Definição operacional: consiste nos aspectos cognitivos (o que é conhecido sobre o processo de mudança, se ela é necessária), afetivos (quais as emoções evocadas pelo processo de mudança) e comportamentais (intenção de apoiar o processo de mudança planejada).

Essas três dimensões foram apresentadas por meio de afirmações positivas na escala de Aderencia à Mudança, de forma a preservar a relação entre o rótulo e as definições constitutivas e operacionais da variável.

\subsubsection{Variáveis pessoais e profissionais}

Vakola, Armenakis e Oreg (2013) relatam que variáveis pessoais e profissionais dos participantes integram os estudos sobre reações a mudança em duas circunstâncias: 1) verificando o efeito sobre as relações entre as variáveis dos diversos modelos de forma exploratória, ou seja, sem uma hipótese guia, ou; 2) com o intuito de verificar um eventual papel moderador. Os autores argumentam que não há um resultado claro dos efeitos mas, de forma geral, as variáveis profissionais apresentaram efeitos estatisticamente significativos em alguns estudos. Dessa forma, embora não componham diretamente o modelo teórico dessa dissertação, as seguintes variáveis pessoais e profissionais também serão investigadas:

Variáveis pessoais: referem-se às características biográficas dos participantes da pesquisa e correspondem à idade dos participantes, escolaridade e gênero.

Variáveis profissionais: referemse a informações relativas ao tempo de serviço (podendo ser entendido como experiência), a localização na estrutura do órgão (finalística/meio), ao cargo ocupado pelos participantes, se ocupa posição de chefia e se participou ou não do processo de mudança organizacional desde o seu início.

\subsubsection{Variável critério/dependente}

Resultado Percebido

Essa definição é baseada na definição de mudança apresentada por Neiva (2004), ressaltando a alteração nos componentes que caracterizam a organização como um todo e que 
resultem em algum tipo de resultado para a sobrevivência da organização, não importando a intencionalidade ou a fonte de alteração.

Definição constitutiva: Essa variável é definida como o grau de alinhamento entre o modelo hipotetizado pelos idealizadores do processo de mudança e a mudança efetivamente percebida pelos servidores das unidades afetadas. Cada item representa um resultado apontado como desejado pelos planejadores da mudança

Definição operacional: apresenta um conjunto de 12 variáveis que apresentam certos aspectos relatados no Estudo 1, que foram avaliados pelos participantes do Estudo 2 por meio de variável dicotômica. É a avaliação dicotômica dos participantes sobre os itens apresentados na escala.

\subsubsection{Variável moderadora}

Para estabelecer relações de moderação entre a aderência à mudança e a percepção de mudança organizacional, utilizou-se uma variável contextual, a estrutura organizacional. É importante salientar que, tradicionalmente, variáveis contextuais são estudadas como preditores das reações à mudança. Esse estudo pretende testar quais os possíveis efeitos dessa variável na relação entre reações à mudança e a percepção dos resultados de mudança organizacional. Devido à amplitude do construto, decidiu-se operacionalizá-lo em função de seus componentes.

Estrutura organizacional:

Definição constitutiva: conjunto formado pela especificação das responsabilidades dos níveis hierárquicos, pela distribuição de autoridade, pelo sistema de comunicação e pelas decisões das unidades organizacionais (Oliveira, 2011).

Definição operacional: consiste nos sistemas de responsabilidades, de autoridade, de comunicação e de decisão, conforme definido por Oliveira (2011).

\subsection{Hipóteses de pesquisa}

Os estudos empíricos sobre atitudes frente a mudança advém da proposição teórica de que atitudes são bons preditores de comportamentos futuros. No caso dos estudos sobre mudança organizacional, esses comportamentos futuros dos indivíduos, entendidos como as reações frente à mudança, são importantes porque são um dos fatores que contribuem para processos de mudança bem-sucedidos ou, no caso da resistência à mudança, para o seu fracasso. 
A resistência à mudança foi, por muito tempo, a reação à mudança mais estudada com base em duas percepções: (i) essa era a reação principal de todos os funcionários em ocasiões de mudança porque essa é a natureza das pessoas frente a situações de incerteza e, (ii) por representar uma barreira a uma intervenção necessária à eficiência (ou sobrevivência), deveria ser combatida. Essa percepção tem sido questionada na literatura em sua premissa ontológica de que as reações à mudança seriam unicamente negativas (Lines, 2005), na pressuposição de que seriam sempre prejudiciais à organização e não possuem potencial de contribuir para a implementação de mudanças e de que, muitas vezes, são os gestores da mudança que determinam quais comportamentos enquadram-se nessa definição (Hernandez \& Caldas, 2001; Ford et al, 2008).

Em estudos empíricos quantitativos, a influência das reações dos indivíduos frente à mudança sobre a implementação efetiva de um processo de mudança é mais comumente investigada utilizando-se resultados organizacionais - rotatividade, desempenho, comprometimento afetivo - e pessoais - bem estar, ansiedade, estresse, intenção de sair, absenteísmo - dos processos de mudança investigados (Oreg et al, 2011).

Da revisão de literatura, depreende-se que estudos empíricos, especialmente quantitativos, que investigam a relação entre reações à mudança (sob a forma de comportamentos e atitudes) e o sucesso de intervenções são mais raros. Como exemplo, podem-se citar dois estudos: o de Jacobs, Keegan e Christe-Zeye (2006), em que se pesquisou os fatores percebidos que influenciariam o sucesso de projetos de mudança organizacional em uma organização policial por meio de entrevistas; e o de Ben-Gal e Tzafir (2011), que investigaram a relação entre o comprometimento com a mudança (constructo de natureza afetiva) com a efetividade da mudança, definida em termos da velocidade de implementação e qualidade da implementação da mudança, em processos de mudança organizacional que contou com a participação de consultores.

Diante da importância que o constructo atitudes tem ganhado nos estudos empíricos e modelos teóricos sobre reações à mudança; do fortalecimento de uma corrente conceitual de atitudes positivas frente à mudança; e da conexão entre reações positivas e sucesso nos processos organizacionais, propõe-se a seguinte hipótese de estudo:

H1 - aderência à mudança está positivamente relacionada com os resultados efetivos percebidos pelos funcionários da organização. 
A segunda hipótese de trabalho diz respeito ao papel moderador dos componentes da estrutura organizacional. Tradicionalmente, variáveis contextuais são percebidas como preditores de reações à mudança, e fazem parte do componente processual da análise. São exemplos dessas variáveis os processos de comunicação formal e informal (Rafferty \& Restubog, 2010), o grau de participação no processo de decisão sobre mudança organizacional (Kim, Hornung \& Rousseau, 2011) e elementos que podem fazer parte da estrutura informal, tais como rotinas organizacionais, valores, interesses, dinâmicas de poder (Greenwood \& Hinings, 1996).

Um dos estudos apresentados no referencial teórico hipotetiza que fatores estruturais podem ter um papel moderador na relação entre atitudes e percepção de mudança organizacional (Voet, 2014). O papel moderador dos componentes da estrutura pode ser especialmente importante para dar pistas sobre outros elementos relativos ao contexto da mudança (por exemplo, sistemas de comunicação).

Dessa forma, pode-se apresentar a seguinte hipótese:

H2: os componentes da estrutura organizacional influenciarão na relação entre aderência à mudança e percepção de mudança organizacional.

Uma hipótese adicional diz respeito a possíveis diferenças entre a percepção individual e a grupal (Mowday \& Sutton, 1993), e à influência que processos cognitivos coletivos podem ter sobre a formação das reações e narrativas individuais sobre a mudança (Pieterse, Caniëls \& Homan, 2012). Essas suposições coadunam com a concepção da mudança organizacional como um fenômeno multinível, apresentando-se como uma alternativa epistemológica coerente com essa concepção. Ainda assim, essa é uma relação pouco explorada empiricamente nos estudos sobre atitudes frente à mudança. Dessa forma, uma terceira hipótese seria a seguinte:

H3: haverá diferenças estatisticamente significativas na formação da aderência à mudança entre os grupos das áreas fim e meio, sendo que os integrantes da área fim apresentarão maior aderência à mudança.

O modelo teórico hipotetizado dessa dissertação pode ser representado pela Figura 4. 


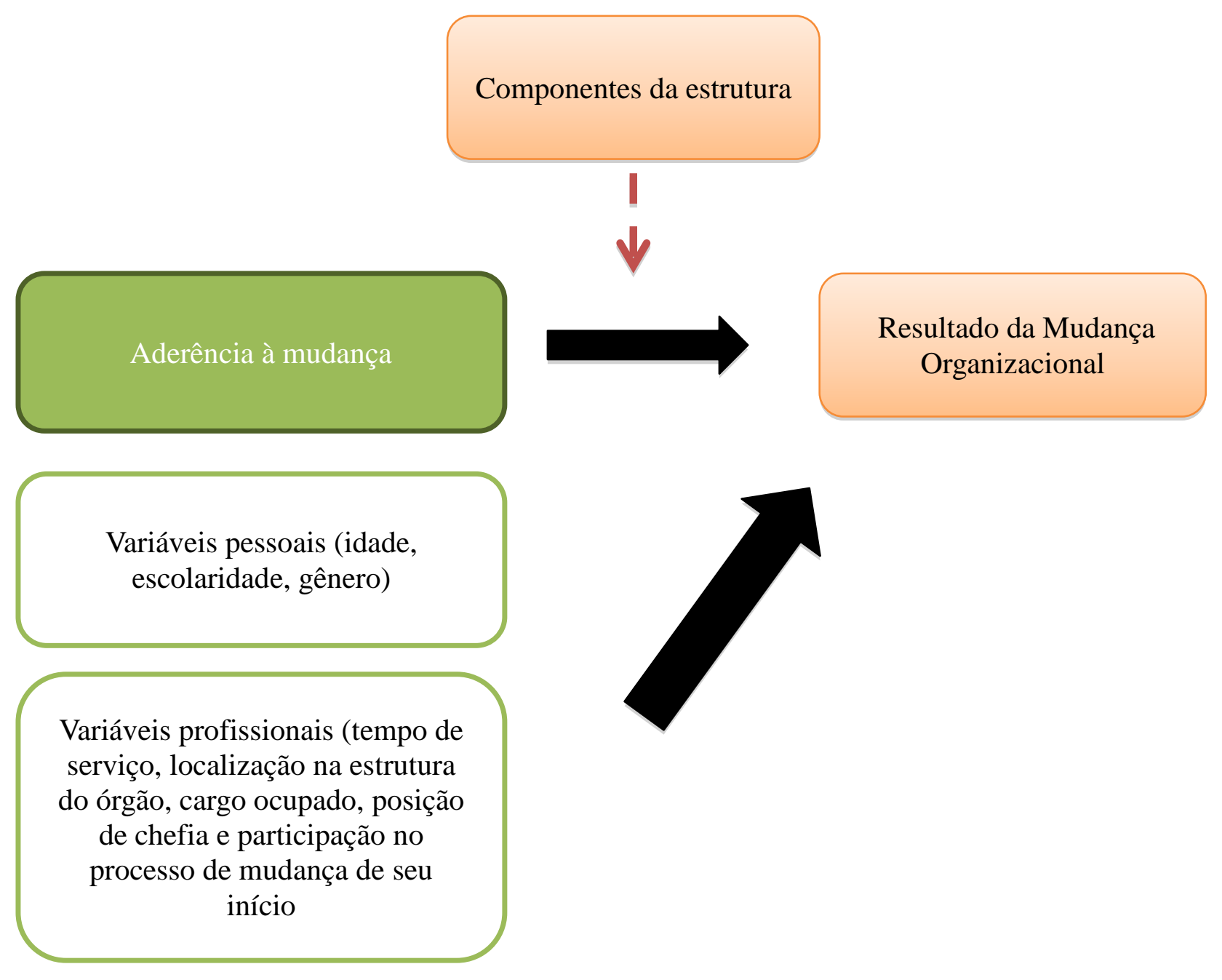

Figura 4. Representação gráfica do modelo teórico

Fonte: elaborada pela autora

A Tabela 4 sintetiza as variáveis do modelo e suas definições.

Tabela 4.

\section{Definição das variáveis}

\begin{tabular}{|lll|}
\hline Variáveis & Definição Constitutiva & Definição Operacional \\
\hline Aderência à Mudança & Atitude pró-mudança frente, ou seja, Aspectos cognitivos (o que é \\
& é a predominância de cognições, conhecido sobre o processo de \\
& afetos e intenção de comportamentos mudança, se ela é necessária), \\
positivos frente a uma situação de & afetivos (quais as emoções evocadas \\
& mudança organizacional percebida e pelo processo de mudança) e \\
& pode gerar comprometimento com o comportamentais (intenção de apoiar \\
& sucesso dessa mudança. & o processo de mudança planejada). \\
& Essa medida foi criada com base em \\
\hline
\end{tabular}




\begin{tabular}{|c|c|c|}
\hline Variáveis & Definição Constitutiva & Definição Operacional \\
\hline & & Voet (2014). \\
\hline Resultado percebido & $\begin{array}{l}\text { Grau de alinhamento entre o modelo } \\
\text { hipotetizado pelos idealizadores do } \\
\text { processo de mudança e a mudança } \\
\text { efetivamente percebida pelos } \\
\text { servidores das unidades afetadas. } \\
\text { Cada item representa um resultado } \\
\text { apontado como desejado pelos } \\
\text { planejadores da mudança }\end{array}$ & $\begin{array}{lll}\text { Avaliação dicotômica } & \text { dos } \\
\text { participantes } & \text { sobre cada um } & \text { dos } \\
\text { resultados apresentados. } & & \end{array}$ \\
\hline Estrutura organizacional & $\begin{array}{l}\text { Conjunto formado pela especificação } \\
\text { das responsabilidades dos níveis } \\
\text { hierárquicos, pela distribuição de } \\
\text { autoridade, pelo sistema de } \\
\text { comunicação e pelas decisões das } \\
\text { unidades organizacionais (Oliveira, } \\
\text { 2011). }\end{array}$ & $\begin{array}{l}\text { Sistemas de responsabilidades, de } \\
\text { autoridade, de comunicação e de } \\
\text { decisão. }\end{array}$ \\
\hline Variáveis pessoais & $\begin{array}{l}\text { Características biográficas } \\
\text { participantes }\end{array}$ & Idade, Escolaridade e Gênero \\
\hline Variáveis profissionais & $\begin{array}{lll}\text { Características profissionais dos } \\
\text { participantes }\end{array}$ & $\begin{array}{l}\text { Referem-se a informações relativas } \\
\text { ao tempo de serviço (podendo ser } \\
\text { entendido como experiência), a } \\
\text { localização na estrutura do órgão } \\
\text { (finalística/meio), ao cargo ocupado } \\
\text { pelos participantes, se ocupa posição } \\
\text { de chefia e se participou ou não do } \\
\text { processo de mudança organizacional } \\
\text { desde o seu início. }\end{array}$ \\
\hline
\end{tabular}

Fonte: Elaborada pela autora

O Capítulo 3 apresentou o modelo teórico hipotetizado dessa dissertação, com a definição das variáveis a serem investigadas e as hipóteses de pesquisa. A seguir, serão apresentados os estudos que embasaram a verificação empírica das relações propostas. 


\section{MÉTODO}

Neste Capítulo serão apresentados o processo de mudança no Conselho Administrativo de Defesa Econômica - Cade e a estrutura dos três estudos conduzidos para verificação empírica das relações hipotetizadas no Capítulo 3. Os estudos serão apresentados em seus objetivos, população/participantes e método de coleta e análise de dados.

\subsection{O processo de mudança organizacional no Conselho Administrativo de Defesa Econômica}

O Cade é uma autarquia federal vinculada ao Ministério da Justiça, e é responsável pela formulação e implementação da política pública de defesa da concorrência. O Cade tem sua atuação determinada pela Lei n. 12.529 (2011). A autarquia possui três eixos de atuação: preventivo, por meio do controle das fusões e aquisições de empresas cujos efeitos possam causar repercussão em território brasileiro; repressivo, por meio da apuração de infrações à ordem econômica; e educativo, por meio da difusão da cultura da concorrência para a sociedade.

O Cade passou por um processo de alteração de suas competências com a entrada em vigor da Lei n. 12.529 (2011). Anteriormente, o Cade tinha a função de Tribunal Administrativo, ou seja, proferia decisões colegiadas para os processos administrativos instruídos por duas outras entidades, Secretaria de Direito Econômico do Ministério da Justiça - SDE/MJ, e a Secretaria de Assuntos Econômicos do Ministério da Fazenda - Seae/MF. Essa Lei determinou que as funções de instrução da SDE (que foi extinta) e da Seae (que permaneceu com a função de difusão da cultura da concorrência, dentre outras que já possuía) fossem incorporadas ao Cade em uma nova unidade organizacional, a Superintendência Geral. A Lei também previu a alteração do regime de análise de Atos de Concentração de a posteriori (após a celebração do negócio) para a priori (ou seja, o negócio só pode ser concretizado com a aprovação da autarquia) e a expansão da estrutura, com a criação de cargos. Essas mudanças tiveram de ser implementadas no prazo de 6 meses previstos pela Lei, e em 30 de maio de 2012 o Novo Cade começou a funcionar com uma nova estrutura, novas competências e uma equipe oriunda dos três órgãos.

A preparação para o processo de mudança iniciou-se antes da aprovação do projeto de lei que deu origem à Lei de Defesa da Concorrência. Segundo o Presidente da Autarquia, alguns 
aspectos do funcionamento do que viria a ser o Novo Cade, tais como o desenho da estrutura organizacional e o processo de análise de Atos de Concentração, começaram a ser discutidos aproximadamente um ano antes da aprovação da Lei, em virtude da percepção de evolução do projeto de lei no Congresso Nacional em 2010. A partir desse momento, o Conselho do Cade (em conjunto com o Secretário de Direito Econômico à época, e atual Presidente do Cade) incumbiu um grupo de servidores da tarefa de desenhar um arranjo de gestão para o processo de mudança organizacional, com base em um conjunto de necessidades identificadas: i) estrutura organizacional; ii) uma nova sede para acomodar a expansão da autarquia, uma vez que o projeto de lei previa a criação de uma série de cargos a serem alocados no Cade ; iii) prospecção de um sistema de processo eletrônico; iv) criação do novo processo de análise de Atos de Concentraçao; v) elaboração do novo Regimento Interno e outros atos normativos; e vi) grupo de Mobilização e Alinhamento, dedicado a fazer a ponte entre os grupos de transição e os funcionários do Cade. Cada um desses grupos era liderado por um Conselheiro do Cade. A coordenação dos grupos era feita pelo Secretário de Direito Econômico à época.

Os grupos de transição tiveram durações diferentes. Iniciaram-se ao final de 2010 os grupos voltados a estrutura, nova sede e novo processo de análise de $\mathrm{AC}$ e, a partir da aprovação do projeto de lei, em novembro de 2011, os outros grupos passaram a funcionar de forma mais sistemática. Formalmente, o início do processo de transição deu-se nos 6 meses que antecederam a entrada em vigor da nova Lei de Defesa da Concorrência, embora seu planejamento tenha sido iniciado antes. O processo de implementação dessa mudança organizacional é o objeto desse projeto. Investigou-se quais as atitudes dos indivíduos frente a esse processo de mudança e sua relação com os resultados percebidos pelos funcionários do Cade.

Este Capítulo descreve o método proposto para a pesquisa, contribuindo para a definição dos participantes do estudo, dos instrumentos a serem utilizados e dos procedimentos de coleta e análise de dados. A pesquisa foi estrutura em torno de três estudos, cada um com definição de população e amostra, procedimento de coleta e de análise de dados. O primeiro estudo foi dedicado a construção das escalas de aderência à mudança e de resultados percebidos; o segundo estudo testa empiricamente as hipóteses de pesquisa apresentadas no Capítulo 3; e o terceiro estudo buscou aprofundar os resultados encontrados nos estudos 1 e 2 . 
A estratégia de análise de dados dessa dissertação foi a triangulação metodológica por complementação, com o objetivo de diminuir o viés decorrente da análise de resultados advindos de apenas um método de coleta (Podsakoff, Mackenzie \& Podsakoff, 2011); ainda assim, é necessário reconhecer os possíveis vieses de auto-relato, uma vez que as variáveis do modelo teórico são medidas de percepção individual.

A seguir, é apresentada a estrutura de cada um dos estudos.

\subsection{Estudo 1}

O estudo 1 consiste em uma fase qualitativa e descritiva da pesquisa, cujo principal objetivo é fornecer insumos para a elaboração do instrumento relativo a variável dependente do estudo Resultado da Mudança Organizacional e à variável independente Aderência à Mudança.

\subsubsection{População e Amostra}

Nessa primeira etapa, foram entrevistados os principais líderes identificados do processo de mudança organizacional do Cade, assim como eventuais funcionários indicados por eles como atores importantes do processo. Os primeiros entrevistados foram o ex-Secretário de Direito Econômico (atual presidente do Cade) e o Conselheiro responsável por liderar a criação do novo fluxo de análise de Atos de Concentração. Eles indicaram que a Chefe de Gabinete à época fosse entrevistada que, por sua vez, indicou a Coordenadora-Geral de Orçamento, Finanças e Logística.

Buscou-se entrevistar outros atores que tiveram posições-chave para o processo de mudança, tais como os outros Conselheiros e o Presidente do Cade à época, mas não foi possível ouvi-los em virtude de problemas de agenda. Dessa forma, foram entrevistadas as seguintes pessoas:

- O Secretário de Direito Econômico a época, e atual Presidente do Cade. Assumiu um papel de grande liderança no processo de mudança;

- O Conselheiro responsável pelo desenho da nova sistemática de análise de Atos de Concentração - principal processo de trabalho finalístico alterado pela Lei de Defesa da Concorrência -, que tornou-se o primeiro Superintendente-Geral do Cade; 
- A Chefe de Gabinete à época, responsável por apoiar a mudança em sua parte administrativa e coordenar os grupos responsáveis pela proposta de organograma e pela comunicação interna aos servidores; e

- A Coordenadora-Geral de Orçamento e Finanças à época, responsável por viabilizar todos os processos aquisitivos e outras providências administrativas da mudança.

Também foi solicitado aos entrevistados que sugerissem eventuais documentos produzidos durante o processo de mudança. Foi indicada a leitura do Relatório de Gestão do Cade referente ao ano de 2012 e a página na intranet em que foram descritos os grupos criados para implementar a mudança organizacional.

\subsubsection{Procedimentos de coleta de dados}

No Estudo 1, foram realizadas pesquisa documental e entrevistas, conforme relatado no item 4.2.1.

Iniciou-se o estudo pelas entrevistas com as autoridades. Foram realizadas entrevistas semi-estruturadas, ou baseada em roteiro (Godoi \& Mattos, 2010), para mapeamento do processo de intervenção e dos resultados esperados do processo, com o objetivo tanto de caracterizar o processo de intervenção para a elaboração dos itens do instrumento dedicado à verificação do resultado da implementação do processo de mudança organizacional. As entrevistas seguiram o seguinte roteiro:

- Defina o que, na sua opinião, mudou aqui no Cade;

- Como a intervenção foi desenhada? Foi utilizada alguma ferramenta ou técnica específica de intervenção?

- O que era esperado da mudança?

- O que facilitou/dificultou a mudança?

- Quais as reações verificadas junto aos servidores, na sua opinião?

Durante o levantamento de documentos a serem analisados, percebeu-se que o processo de mudança organizacional não foi sistematicamente documentado: há alguns relatórios sobre os trabalhos do grupo de sistemas da informação, além de mensagens comunicadas à equipe e 
artefatos produzidos sobre o novo processo de análise de Atos de Concentração e da proposta de organograma. Dessa forma, foram incorporados outros documentos que tratassem de etapas do processo de transição, tais como Relatórios de Gestão ${ }^{1}$ e de monitoramento do Plano Plurianual 2011-2015 (que possui como uma das metas a implantação do Novo Cade), balanços apresentados pelo Cade em sessões de julgamento ${ }^{2}$, bem como livro comemorativo sobre o cinqüentenário da Autarquia e o relato sobre o novo processo de análise de Atos de Concentração fornecido para a $18^{\mathrm{a}}$ edição do Concurso de Inovação da Escola Nacional de Administração Pública (ENAP, 2014).

\subsubsection{Análise dos dados}

Nessa fase utilizou-se a técnica de análise de conteúdo (Bardin, 2011), com o intuito de mapear categorias semelhantes que embasarão a definição das variáveis da medida de Resultado da Mudança Organizacional. As categorias foram retiradas das respostas obtidas nas entrevistas, assim como nos documentos analisados.

Havia-se proposto utilizar o marco lógico (Banco Interamericano de Desenvolvimento [BID], 1997) como estrutura para descrição da lógica da intervenção, caso houvesse sido utilizado alguma espécie de ferramental, ou arcabouço lógico no desenho do processo de mudança organizacional em tela. Como não foi constatado qualquer tipo de ferramenta empregada no desenho da mudança a ser alcançada, o relato dos resultados incluirá a lógica de intervenção a partir da descrição dos entrevistados.

\subsection{Estudo 2}

O Estudo 2 consiste no teste estatístico das hipóteses apresentadas no Capítulo 3, por meio do uso de um questionário formado por três escalas:

- Aderência à mudança - elaborado para a pesquisa, com base em medidas encontradas na revisão de literatura;

\footnotetext{
1 Relatório anual de prestação de contas para o Tribunal de Contas da União. Disponível em http://www.cade.gov.br/Default.aspx?d95ada25eb2aea4fe168, com acesso em 21 de fevereiro de 2015.

${ }^{2}$ As apresentaçoes podem ser acessadas no sítio eletrônico do Cade, menu Sala de Imprensa, Balanços e Apresentações. Disponível em http://www.cade.gov.br/Default.aspx?68c84bd55ab87bdf7cdf, com acesso em 22 de fevereiro de 2015.
} 
- Resultados percebidos - elaborado para a pesquisa; e

- Componentes da estrutura - foi utilizado o instrumento elaborado por Coelho Jr., Quadros, Oliveira e Maciel (sem data), ainda em processo de validação

Trata-se de estudo exploratório, descritivo e explicativo. Segundo Richardson (2010, p. 71), uma pesquisa descritiva e explicativa propõe-se a descobrir as características do fenômeno de interesse como ele é, e compreender o comportamento de determinados elementos que influem sobre determinado fenômeno. Para tal fim, essa pesquisa também permite o estudo de relações hipotetizadas entre as variáveis, que podem fornecer pistas importantes para estudos futuros.

\subsubsection{População e Amostra}

O objetivo desse estudo é investigar a relação entre atitudes frente à mudança e os resultados percebidos de um processo de mudança organizacional com impactos em diversos componentes de uma organização. Conforme apresentado na seção 4.1, foi escolhido o Conselho Administrativo de Defesa Econômica, Organização que passou por um processo de mudança organizacional profundo em 2012, com alteração de suas competências legais, processos de trabalho e estrutura organizacional.

A população desse estudo é formada por servidores e colaboradores terceirizados lotados atualmente nas áreas finalística e administrativa do Cade. A inclusão dos colaboradores terceirizados justifica-se na medida em que eles exercem funções de apoio fundamentais ao funcionamento da área finalística e administrativa no que tange ao andamento processual - por exemplo, serviço de andamento processual, acompanhamento de prazos e apoio à produção de estatísticas -, e, em tese, seus processos de trabalho foram impactados pela mudança nos ritos processuais da Autarquia. Também foram contactados ex-servidores do Cade que participaram do processo de mudança, com o intuito de enriquecer a amostra desse estudo com mais participantes que eram parte do Sistema Brasileiro de Defesa da Concorrência à época da mudança.

O tamanho da amostra mínima necessária para a aplicação da regressão logística nesse estudo é de 100 observações, em virtude do número de categorias da variável dependente, segundo Hair, Black, Babin, Anderson e Tatham (2009). Além disso, Pasquali (2005) recomenda entre 5 e 10 observações para cada item do instrumento para que seja possível realizar a validação de um instrumento. O Cade contava à época com menos de 150 servidores e, após a 
mudança, a população-alvo desse estudo estava em torno de 250 pessoas, entre servidores e terceirizados. Dessa forma, como estratégia para atender aos requisitos dos testes estatísticos empregados nesse estudo, realizou-se um censo no Conselho.

\subsubsection{Procedimentos de coleta de dados}

A coleta de dados foi feita utilizando instrumento composto de 3 medidas: (i) medidas sobre a variável aderência à mudança, (ii) medidas sobre a variável percepção de resultado de mudança organizacional e (iii) medidas de componentes da estrutura. O questionário foi aplicado presencialmente aos funcionários que trabalham no Cade, e virtualmente para os ex-funcionários da amostra. O período de coleta de dados foi de outubro a novembro de 2014.

\subsubsection{Medida de Aderência à Mudança}

Com base na revisão de literatura e nas entrevistas realizada no Estudo 1, foi criada uma medida relativa a variável aderência à mudança, cujos itens foram elaborados com base em 3 dimensões teóricas: cognições (o que se sabe sobre a mudança específica e sobre o processo como um todo), afetos (emoções percebidas pelo participante sobre ele mesmo e sobre as pessoas a sua volta) e intenção de comportamento (os itens propostos para essa dimensão foram adaptados de Voet, 2013), avaliada, no caso específico, nos comportamentos exibidos à época do processo. O formato da medida é o de uma escala tipo Likert de 10 pontos, onde 1 corresponde a "discordo totalmente" e 10 a corresponde a "concordo totalmente".

\subsubsection{Medida de Resultado percebido}

Foi criada uma medida relativa ao constructo resultado percebidos com base nos relatos das entrevistas realizadas no Estudo 1. Foram apresentadas uma série de afirmativas aos participantes sobre os resultados percebidos do processo de mudança organizacional, obtidos a partir das entrevistas realizadas do Estudo 1, ou seja, cada afirmativa corresponde a uma variável. O formato proposto para a medida é dicotômico: os participantes deverão assinalar "Sim" caso concordem com o conteúdo da afirmação, e "Não", caso discordem.

\subsubsection{Escala de Percepção de Componentes da Estrutura Organizacional}


Para a coleta de dados relativos aos componentes da estrutura, foi utilizada a Escala de Percepção de Componentes da Estrutura Organizacional (Anexo III) elaborada por Coelho Jr., Quadros, Oliveira e Maciel (sem data). Esta escala ainda está em processo de validação psicométrica e mede as dimensões estruturais de complexidade, comunicação, centralização, formalização e sistemas de poder. $\mathrm{O}$ instrumento consiste em um questionário estruturado composto por 38 itens no formato de escala do tipo Likert de 10 pontos, onde 1 corresponde a "discordo totalmente" e 10 a corresponde a "concordo totalmente".

É importante salientar que os instrumentos de aderência à mudança e resultados percebidos foram elaborados tendo em consideração o processo de mudança organizacional já ocorrido, e não situações genéricas de mudança organizacional; nessa situação, há possibilidade de vieses de resposta, especialmente no que diz respeito à desejabilidade social das respostas. Dessa forma, os participantes foram orientados a embasarem suas respostas no período que iniciou com a confirmação da ocorrência do processo de mudança - nos caso, aprovação da Lei n. 12.529/2011 e o conseqüente período de vacância até sua efetiva implementação em maio de 2012.

O instrumento de aderência à mudança foi submetido à validação teórica no momento da aprovação do projeto de pesquisa que deu origem a essa dissertação, com o objetivo de identificar inconsistências teóricas. Posteriormente, o instrumento também foi submetido a validação semântica por juízes: foram selecionados 10 funcionários do Cade para aplicação da primeira versão do instrumento completo, com o objetivo de verificar a adequação da linguagem, tempo de resposta e precisão das instruções. Após esse procedimento, a versão final da escala de aderência à mudança (Anexo I dessa dissertação) foi disponibilizada para resposta. No caso da escala de componentes da estrutura organizacional,

A coleta de dados foi realizada por meio de questionário impresso e entregue aos respondentes e disponibilização em ferramenta online, para os ex-servidores. Optou-se por essa estratégia principalmente em função do pequeno tamanho da população acessível (variando entre 200 e 250 funcionários) e da necessidade de um grande número mínimo (proporcionalmente ao tamanho da população) de observações para proceder à análise por regressão logística: Hair et al (2009) recomendam um número de 50 observações por categoria que a variável critério possui. 


\subsubsection{Análise dos dados}

$\mathrm{Na}$ segunda etapa, os dados obtidos com os instrumentos aplicados foram analisados por meio de métodos descritivos e inferenciais.

Inicialmente, foi realizado estudo preliminar das características da amostra e o tratamento de dados, tanto para identificação de possíveis padrões para casos omissos e extremos (Hair et al, 2009; Tabachnick \& Fidell, 2007). As primeiras características avaliadas foram a normalidade (verificada por meio da análise de assimetria e curtose), média, variância e desvio padrão das variáveis escalares, bem como a freqüência das variáveis ordinais.

Hair et al (2009) recomenda o alinhamento de testes empíricos (por exemplo, aferição da assimetria e curtose) a técnicas gráficas, tais como o histograma ou o diagrama de ramo-e-folhas, no caso de variáveis métricas (essa técnica aplica-se ao exame da variável aderência à mudança), e o diagrama de caixas (box-plot), no caso de interesse em relações bivariadas para o exame da diferenças entre grupos - essa técnica se aplica ao exame das relações bivariadas que envolvam as variáveis resultado da mudança organizacional (hipótese 1) e área de lotação (hipótese 3).

No caso da etapa 2 do Estudo 1, os casos omissos foram analisados por meio da ferramenta de análise de casos omissos MVA (Missing Variable Analysis). As observações atípicas univariadas e multivariadas foram identificadas por meio do uso do diagrama Box-plot e por meio do uso da distância de Mahalanobis, conforme indicado por Tabachnick e Fidell (2007).

A análise fatorial é uma técnica estatística de redução de um conjunto de variáveis altamente correlacionadas entre si, de forma que o gerenciamento do conjunto de dados pelo pesquisador seja facilitado, seja pela redução do numero de variáveis (e correção de fenômenos como a singularidade) ou pela criação de uma nova medida capaz de representar um grupo de variáveis (Hair et al, 2009). Essa técnica é especialmente útil na identificação de dimensões subjacentes de fenômenos objeto de estudo das ciências sociais (Field, 2009); porém, o seu resultado final é fruto da avaliação da capacidade explicativa e de coerência interna da solução estatística apresentada, e deve apoiar-se na teoria acerca da variável latente pesquisada (Tabachnick \& Fidell, 2007).

A análise fatorial exploratória foi empregada para validação da estrutura proposta na escala de Aderência à Mudança. No caso da escala de Componentes da Estrutura Organizacional (Coelho Jr., Quadros, Oliveira \& Maciel, sem data), a análise fatorial foi utilizada para a 
identificação das dimensões latentes dos dados, de forma que se proceda ao teste da hipótese 2 desse estudo - identificação de possível efeito moderador da variável estrutura organizacional na relações identificadas por meio das regressões logísticas.

A regressão logística é uma técnica de regressão multivariada empregada quando há uma única variável critério e esta é dicotômica, e permite que seja identificada padrões discretos em variáveis (por exemplo, pertencimento a um grupo) a partir de variáveis preditoras contínuas ou categóricas (Tabachnick \& Fidell, 2007). Segundo Hair et al (2009), a regressão logística é um caso especial de análise discriminante justamente por ser utilizada quando a variável critério é dicotômica, ou seja, possui duas categorias.

A regressão logística é, em muitos aspectos, similar à regressão linear multivariada, uma vez que transforma a variável dependente dicotômica em escalar, por meio da transformação logit. Pelo fato da relação entre as variáveis ser, por natureza, não linear, a regressão logística não exige muitos pressupostos, tais como a normalidade das variáveis, para ser utilizada

O modelo computa a combinação de variáveis dependentes que melhor explica a distribuição das observações em uma ou outra categoria, maximizando a variância entre os grupos e minimizando a variância dentro deles. São pressupostos a normalidade multivariada das variáveis independentes e a igualdade das matrizes de covariância entre os grupos; ainda assim, os autores ressaltam que esse teste suporta bem violações ao pressuposto da normalidade (Hair et al, 2009), ou seja, é uma técnica mais flexível, uma vez que há poucos requisitos das variáveis, e comporta, inclusive, relações não lineares entre as variáveis por meio da transformação logarítmica. Assim como na regressão múltipla, é possível realizar a regressão logística direta, hierárquica e estatística, também conhecida como stepwise. O ultimo modelo é o indicado para estudos exploratórios

A regressão logística baseia-se na análise da máxima verossimilhança (ML), ou seja, essa técnica maximiza a probabilidade de que um evento ocorra para estimar as relações entre as variáveis por meio da comparação entre modelos de predição. De forma geral, na regressão logística são comparados os valores de máxima verossimilhança entre um modelo inicial para se verificar um bom ajuste do modelo proposto (e há, conseqüentemente, uma redução na quantidade de variância não explicada, representada pela estatística), e os testes dos preditores individuais. 
Normalmente, o modelo inicial possui apenas uma constante, e é comparado a um modelo com a(s) variável(eis) em questão (Tabachnick e Fidell, 2007). Ainda segundo as autoras, a diferença entre esses valores é multiplicada por dois para criar uma estatística qui-quadrado $\left(\chi^{2}\right)$, e é esperado que haja uma alteração nesse valor com a adição/supressão de variáveis. Além da alteração de LL, espera-se obter um resultado significante na estatística qui-quadrado. Outra estatística importante é o teste de Hosmer-Lemeshow, que compara os resultados previstos pelo modelo e os obtidos; no caso desse teste, um bom modelo produz um resultado não significante (Hair et al., 2009), ou seja, não há diferença estatisticamente significante entre os resultados previstos e os encontrados.

Para a estimação da equação de regressão, a estatística de referencia é a de Wald (W). Se uma variável apresenta uma estatística de Wald significante, ela é inserida (ou mantida) no modelo. Segundo Tabachnick e Fidell (2007), a interpretação do coeficiente de cada variável indica o aumento na chance da categorização em um determinado grupo. Usualmente, o valor interpretado é conhecido como razão de chance (odds ratio), e representa o coeficiente exponenciado de cada variável. As autoras indicam que a razão de chance pode ser interpretada como o efeito: quanto mais próximo de um, menor o efeito, e sua interpretação é multiplicativa (no caso, um coeficiente de 2 significa duas vezes mais chance de observar um resultadoreferência, como a classificação em um determinado grupo); além disso, caso o intervalo de confiança da medida contenha o intercepto, há indícios de que a variável não contribui para a equação.

Para a medida de efeito total do modelo, será utilizada o $\mathrm{R}^{2}$ de Nagelkerke (medida chamada pseudo-R e que se assemelha ao coeficiente de regressão), indicando o total da variância explicada pelo modelo. Essa medida é indicada pelo fato de variar entre 0 e 1 , sendo sua interpretação bastante semelhante ao $\mathrm{R}^{2}$ obtido em um modelo de regressão linear múltipla (Hair et al, 2009).

Foram utilizados a análise de verossimilhança logarítmica e da regressão logística. A análise de verossimilhança logarítmica corresponde à análise de correlação utilizada para o teste de relação linear entre variáveis contínuas. A verossimilhança logarítmica permite a análise da relação entre variáveis métricas e não métricas por meio da transformação logarítmica, o que possibilita o estabelecimento de relação linear entre as variáveis. A análise por regressão logística 
foi utilizada para testar as relações entre as variáveis aderência à mudança e resultado da mudança $(\mathrm{H} 1)$ e o efeito moderador da estrutura sobre essa relação $(\mathrm{H} 2)$, uma vez que a variável critério é dicotômica.

Pretendeu-se também verificar se há diferenças significativas nas percepções entre indivíduos e grupos; no caso específico, averiguar se os resultados apresentam diferenciação na variável lotação (área fim ou meio). Para tal análise, foi realizado um teste de comparação entre médias. Agresti e Finlay (2012) apontam que, para o teste de relações bivariadas, em que a variável que define o grupo é binária e os grupos são independentes, pode-se utilizar o teste $t$ (baseado na distribuição t), supondo distribuições populacionais normais. Caso esse pressuposto seja violado (por exemplo, amostras pequenas ou distribuições muito assimétricas), poderão ser utilizados testes não paramétricos, tais como o teste de Mann-Whitney U (Hair et al, 2009; Field, 2009), indicado para realizar comparações entre amostras independentes. Esses testes foram úteis para testar a hipótese 3 desse estudo.

\subsubsection{Caracterização da Amostra}

Nessa seção, foram relatados os processos de identificação e tratamento de casos omissos e observações extremos, bem como será apresentado o perfil da amostra do Estudo 2.

Em relação aos casos omissos, a amostra inicial era formada por 186 observações. Em uma análise preliminar, nenhuma das variáveis contava com mais de 5\% de ocorrências omissas; porém, o teste de Little, que indica se o padrão de dados omissos é completamente ao acaso (Tabachnick \& Fidell, 2007), foi não significativo ( $\mathrm{p}<0.05)$.

Ao analisar-se a matriz fornecida pelo pacote estatístico SPSS, percebeu-se que os dados omissos eram aleatórios ao acaso e concentravam-se nas escalas de Aderência à Mudança e Resultados, com algumas observações sem respostas em uma das duas escalas por inteiro. Investigando-se os casos, percebeu-se que eram de funcionários que não haviam passado pelo processo de mudança; mais especificamente, estavam a menos de dois anos no Cade.

Hair et al (2009) e Tabathnick e Fidel (2007) indicam métodos de substituição dos dados, tais como a abordagem Expectation Maximization (EM), em que há estimativa dos dados perdidos (passo E) e dos parâmetros tais como media, moda, desvio-padrão e correlações (passo M), e a o método da imputação múltipla, no caso das variáveis dicotômicas. Porém, considerouse temerário substituir escalas inteiras para uma observação e, como o numero de casos era o 
suficiente para se executar o procedimento estatístico escolhido para a análise, optou-se por excluir as observações em que escalas completas não foram preenchidas. Após retirados, o teste de Little apresentou valor não significativo ( $\mathrm{p}=.018)$, e o tamanho final da amostra foi de 177 observações.

O tamanho total da amostra obtida, após a exclusão dos casos omissos, foi de 177 observações. Desses, 89,83\% (159) são funcionários atuais, e 10,17\% são ex-funcionários (servidores e terceirizados) que passaram pelo processo de mudança organizacional. A amostra está praticamente divida entre homens $(48,6 \%)$ e mulheres $(50,3 \%)$, e tem perfil jovem: $61,72 \%$ tem até 34 anos. Em termos de escolaridade, 88 (49,7\%) possuem ensino superior completo, sendo que $70(39,5 \%)$ possuem pós-graduaçao (mestrado e/ou doutorado) incompleto. Apenas $12,4 \%$ possuem ensino médio incompleto.

Sobre o vínculo funcional dos respondentes, 32,7\% é não servidor (sendo $22 \%$ ocupantes do cargo de Apoio Administrativo, principal cargo terceirizado no Cade), 19,2\% é servidor sem vínculo (ou seja, ocupam cargos de livre nomeação e exoneração). Dos servidores de carreira, 43 $(24,3 \%)$ pertencem à carreira específica de Especialista em Políticas Públicas e Gestão Governamental. Do total de funcionários, 31, 6\% (56) tem até 2,5 anos de serviço, ou seja, chegaram depois que o processo de mudança iniciou-se. Em termos de lotação, 45,8\% (81) trabalham na área fim do Cade (Superintendência-Geral e Tribunal), 28,8\% (51) trabalham nas áreas de suporte direto à área fím (Departamento de Estudos Econômicos e Procuradoria Federal Especializada junto ao Cade), e 25,4\% (45) trabalham na área administrativa (Diretoria Administrativa), e 32,8\% (58) ocupam cargo de chefia.

A Tabela 3 sintetiza as características da amostra.

Tabela 3

\section{Resumo das variáveis demográficas da amostra.}

\begin{tabular}{|c|c|c|}
\hline Variável & Frequência & $\%$ \\
\hline \multicolumn{3}{|l|}{ Idade } \\
\hline Menos de 20 anos & 4 & 2,3 \\
\hline 20 a 24 anos & 19 & 10,9 \\
\hline
\end{tabular}




\begin{tabular}{|c|c|c|}
\hline Variável & Frequência & $\%$ \\
\hline 25 a 29 anos & 36 & 20.6 \\
\hline 30 a 34 anos & 49 & 28 \\
\hline 35 a 39 anos & 29 & 16,6 \\
\hline 40 a 44 anos & 18 & 10,3 \\
\hline Acima de 45 anos & 11,3 & 11,4 \\
\hline \multicolumn{3}{|c|}{ Escolaridade } \\
\hline Ensino médio incompleto & 22 & 12,6 \\
\hline Ensino médio completo & 24 & 13,7 \\
\hline Ensino superior incompleto & 35 & 20 \\
\hline Ensino superior completo & 18 & 10,3 \\
\hline Pós-graduação incompleta & 70 & 40 \\
\hline Pós-graduação completa & 6 & 3,4 \\
\hline \multicolumn{3}{|l|}{ Gênero } \\
\hline Masculino & 89 & 50,9 \\
\hline Feminino & 86 & 49,1 \\
\hline \multicolumn{3}{|c|}{ Tempo de Serviço } \\
\hline 0 a 2,4 anos & 56 & 32,2 \\
\hline 2,5 a 4,9 anos & 48 & 27,6 \\
\hline 5 a 7,4 anos & 22 & 12,6 \\
\hline 7,5 a 10 anos & 18 & 10,3 \\
\hline Mais de 10 anos & 30 & 17,2 \\
\hline \multicolumn{3}{|c|}{ Vínculo funcional } \\
\hline Cargo efetivo & 80 & 45,7 \\
\hline Apoio Administrativo & 39 & 22,3 \\
\hline Outro cargo terceirizado & 22 & 12,6 \\
\hline Servidor sem vínculo & 34 & 19,4 \\
\hline
\end{tabular}




\begin{tabular}{|l|c|c|}
\hline \multicolumn{1}{|c|}{ Variável } & Frequência & $\%$ \\
\hline \multicolumn{1}{|c|}{ Lotaço } & & \\
\hline Superintendência-Geral & 73 & 41,2 \\
\hline Tribunal & 8 & 4,5 \\
\hline Procuradoria & 12 & 6,8 \\
\hline Presidência e assessorias & 32 & 18,1 \\
\hline Diretoria Administrativa & 44 & 24,9 \\
\hline Departamento de Estudos Econômicos & 8 & 4,5 \\
\hline Área meio & 88 & 49,7 \\
\hline Área fim & 89 & 50,3 \\
\hline
\end{tabular}

Fonte: Elaborada pela autora

É importante salientar que foram identificados casos extremos (outliers) na amostra, por meio da utilização da distância de Mahalanobis. No total, foram identificados 31 outliers univariados, cujo perfil foi descrito para subsidiar a tomada de decisão sobre sua manutenção ou exclusão das análises dos dados obtidos.

A subamostra dos casos extremos é formada por $61,3 \%$ de mulheres e $38,7 \%$ de homens. A maior parte dos sujeitos possui entre 25 e 34 anos (51,6\%); 16,1\% possuem até 24 anos de idade, e apenas 19,3\% possuem mais de 40 anos. Sobre o grau de escolaridade, a maioria $(48,7 \%)$ possui ensino superior completo ou pós graduação incompleta, resultado compatível com o obtido na amostra.

Em termos de composição do perfil profissional, os casos extremos identificados são formados predominantemente por funcionários (servidores ou terceirizados) do Cade $(87,1 \%)$. Analisando o vinculo funcional, $42 \%$ são servidores de carreira (sendo que 6,5\% são servidores do quadro do Cade), 22,6\% são servidores sem vinculo e 32,2\% ocupam cargos terceirizados. Dos componentes da subamostra, 38,7\% possuem até 2,5 anos de serviço no Cade (ligeiramente maior do que o percentual observado na amostra total), 25,8\% possuem entre 2,6 a 4,9 anos e $35,5 \%$ possuem mais de 5 anos de lotação no Cade. Apenas 4 (12,9\%) ocupam posição de chefia, o que é bastante diferente do perfil amostral, com 32,8\% ocupando cargo de chefia. 
Os outliers possuem em comum o fato de que todos apresentaram medidas inferiores às medias das variáveis que compõem as escalas de Aderência à Mudança e de Componentes da Estrutura Organizacional. Nesse sentido, pode-se hipotetizar que esses sujeitos demonstraram uma formação de aderência à mudança menor, indicando a existência, na amostra, de sujeitos com reações ambíguas à mudança, ou até mesmo de resistência à mudança, conforme proposto por Lines (2005) e Piderit (2000). Observando-se apenas as porcentagens apresentadas, percebese que a principal diferença entre os casos extremos e a amostra é a variável chefia, o que pode indicar um maior distanciamento das iniciativas de comunicação e construção do processo de mudança, especialmente considerando-se que a maior parte desses sujeitos estava presente no processo de mudança organizacional.

\subsection{Estudo 3}

A técnica do grupo focal é um tipo de entrevista em profundidade realizada em grupo, cujo foco é permitir que os participantes interajam, influenciem uns aos outros pelas respostas às idéias e colocações durante a discussão, sendo o resultado transcrito dessas discussões (M. Oliveira \& Freitas, 2012). Os autores ressaltam que essa técnica é indicada quando se deseja obter o entendimento dos participantes sobre o tema de pesquisa, e pode ser usada como uma pesquisa preliminar ou para esclarecer resultados de outros estudos. Na mesma linha, Gaskell (2007) afirma que a entrevista qualitativa (individual ou em grupo) pode desempenhar papel fundamental na combinação com outros métodos

O papel do moderador também muda, de acordo com a finalidade do grupo focal: Oliveira e Freitas (2012) recomendam que o envolvimento seja baixo quando se tratar de pesquisa exploratória; níveis mais altos de envolvimento podem ocorrer quando se houver uma agenda a cumprir, ou se desejar comparar o pensamento do grupo com outros achados. Em termos de tamanho, os autores indicam um grupo de 6 a 16 pessoas, sendo que, a partir de 12, é recomendada a divisão do grupo.

O Estudo 2 foi realizado por meio de grupo focal com funcionários da área meio e fim do Cade, além de entrevista com um-ex integrante da área finalística que fazia parte da Secretaria de Direito Econômico. O objetivo desse estudo é o de complementar os resultados obtidos no Estudo 1 por meio da triangulação metodológica. A diversidade de fontes é importante para dirimir 
possíveis vieses nos resultados advindos de uma única fonte (Donaldson \& Grant-Valone, 2002), e também contribuirá para uma compreensão dos resultados sob múltiplos ângulos.

\subsubsection{Participantes do estudo}

Os participantes do grupo focal foram escolhidos por conveniência. Foram convidados 10 participantes para o grupo focal com perfil semelhante aos encontrados nos outliers identificados na etapa 2; em especial, buscou-se funcionários que trabalhassem no Cade e/ou na SDE à época da entrada em vigor da Lei no. 12.529/2011 e que não ocupassem cargo de chefia à época. O perfil desejado não foi segmentado em termos de gênero, idade ou vínculo funcional com o Cade.

O perfil final do grupo focal foi formado por 6 participantes, sendo 5 da área meio (diversas divisões) do Cade e um da área finalística; foram 5 mulheres e 1 homem. Dos 6 participantes, apenas um ocupa cargo de chefia atualmente. O perfil do entrevistado é de um homem que trabalhava na SDE, na área finalística, e não ocupava cargo de chefia à época.

\subsubsection{Procedimentos de coleta de dados}

A coleta de dados foi feita com base no roteiro utilizado nas entrevistas individuais, apresentado na etapa 1 do Estudo 1, com o intuito de comparar as percepções do grupo com o que foi relatado pelos idealizadores da mudança. Um segundo objetivo foi verificar se a percepção do que mudou era congruente com os resultados planejados/definidos pelos pelas lideranças do processo de mudança. Foram incorporados a esse roteiro os achados do Estudo 1 na forma da compreensão das reações verificadas e do seu impacto na consecução da mudança organizacional.

A realização da entrevista deu-se pela necessidade de incorporar a visão de um participante que estivesse fora do Cade, mas em algum dos órgãos do SBDC (SDE/MJ ou Seae/MF). Decidiu-se pela entrevista em virtude da dificuldade em conseguir-se participantes que pudessem participar do primeiro grupo, ou ainda compor um segundo grupo, em virtude de problemas de agenda. 


\section{Resultados}

O Capítulo 5 apresentará os resultados obtidos a partir da execução dos Estudos 1 (entrevista com as autoridades, que geraram insumos para a elaboração da escala de aderência à mudança e de resultados percebidos), do Estudo 2 (teste empírico estatístico do modelo teórico hipotetizado) e do Estudo 3 (relato do grupo focal e da entrevista realizada).

Os dados obtidos com as escalas foram analisados por meio de métodos inferenciais estatísticos. A partir dos dados coletados foram feitos cálculos de médias, distribuição de frequências, análise fatorial exploratória, análises de correlações e regressões. Essas análises permitem que informações de pequenos grupos sejam utilizadas para fazer inferências sobre grandes grupos dos quais os dados foram extraídos. As análises estatísticas foram feitas com o auxílio do software SPSS - Statistical Package for Social Sciences, versão 20.

\subsection{Relato das entrevistas realizadas no Estudo 1}

O relato das entrevistas foi elaborado tendo como roteiro as perguntas que nortearam as entrevistas - cada subitem do item 5.1 corresponde a uma pergunta. A percepção dos entrevistados será apresentada de forma agregada, ou seja, procurou-se mapear os pontos de convergência e/ou divergência. Foram citados atores específicos nos momentos em que se entendeu relevante destacar sua contribuição.

\subsubsection{Mudanças percebidas e esperadas pelos participantes}

A narrativa dos objetivos da mudança giram em torno do resultado do trabalho dos grupos de transição. Especificamente, era garantir condições para o Cade desempenhar seu novo papel institucional, uma vez que não era apenas uma questão de incorporação de competências, mas sim de toda uma nova dinâmica de trabalho. Esse elemento aparece na fala de todos os entrevistados; em especial, um dos entrevistados mencionou a transformação na própria política de defesa da concorrência que advinha de todo esse rearranjo. Seria uma oportunidade também de o Cade ter um novo protagonismo, ter uma atuação mais proativa, uma vez que, segundo o entrevistado, antes o Cade possuía um perfil muito reativo às demandas da SDE/MJ e da Seae/MJ. Dessa forma, depreende-se da fala dos entrevistados que a mudança legislativa foi o gatilho para um processo mais profundo de reflexão sobre a atuação do órgão para o futuro, com as novas atribuições. 
Em termos mudanças mais específicas, citam-se: a obtenção de uma nova sede, adequada para o funcionamento do Cade; criação e implementação do novo processo de análise de Atos de Concentração, que envolveu um processo de pesquisa de melhores práticas, rearranjo de equipes e capacitação dos servidores para lidar com essa nova realidade. A estrutura organizacional do Cade também mudou muito, com o aumento da área meio, que passou a contar com uma Diretoria Administrativa (em vez de apenas duas Coordenações-Gerais); uma nova unidade finalística (a Superintendência-Geral) e uma ampliação geral do quadro de cargos do Cade de 32 para 124, conforme descrito no Decreto n. 7.778 (2012).

$\mathrm{Na}$ área meio, relatou-se a segregação de funções com a nova estrutura, com profissionais capacitados para executá-las, com aumento do escopo de atuação (exemplo da Coordenação-Geral de Gestão de Pessoas) e do montante de trabalho (exemplo da Divisão de Licitação e Contratos). Uma mudança interpretada como negativa é a inadequação do tamanho da equipe, especialmente na área meio. Não foram relatadas mudanças nos fluxos de trabalho, embora se perceba o reflexo do aumento da área fim do Cade. Um dos entrevistados relatou que as unidades haviam ficado mais distantes uma das outras, e que as pessoas tinham menos disposição em cooperar para resolver problemas

\subsubsection{Percepção de planejamento da mudança}

Segundo os relatos, não houve uma metodologia aplicada, ou uma ferramenta, com o intuito de se planejar a intervenção como um todo, além da criação dos 6 grupos de transição como um método de delegar atividades. O processo de mudança, na opinião dos entrevistados, foi planejado desde antes da aprovação do Projeto de Lei. Após a aprovação, foram colocadas datas e metas a serem cumpridos.

O planejamento para a contratação e a adequação da nova sede aparece como principal ponto de planejamento. Outros entrevistados ressaltaram que o processo de planejamento era mais informal, contando com o compartilhamento de lideranças. Os entrevistados ressaltam que a condução foi feita por pessoas que conheciam a fundo o Sistema Brasileiro de Defesa da Concorrência e que, por isso, conseguiram antecipar alguns problemas que aconteceriam.

A criação do fluxo de trabalho de análise de Atos de Concentração - AC contou com uma lógica de intervenção e uma metodologia um pouco mais detalhada. Houve pesquisa extensa das melhores práticas, visitas técnicas e diversas discussões sobre qual seria o melhor fluxo. Além 
disso, houve treinamento da equipe do Cade especificamente para análise de ACs, uma vez que não se sabia qual seria a formação das equipes. O desenho do processo de análise de atos de concentração foi mais planejado, com uma lógica de intervenção definida: melhorar o tempo médio de análise por meio da instituição de filtros mais eficientes (inclusive, com resultados divulgados).

O principal elemento de planejamento foi a criação dos grupos de transição, com o compartilhamento de lideranças. A coordenação horizontal desses grupos coube ao ex-Secretário e à ex-Chefe de Gabinete. Sobre a articulação entre os grupos de transição, há duas opiniões, uma de que houve articulação entre eles, e outra de que os grupos trabalhavam de forma autônoma, o que, de certa forma, atrapalhou o andamento dos trabalhos dos outros grupos, pois o arranjo de governança era muito complexo. A principal meta era conseguir preparar o Cade para o novo marco legal da Lei de Defesa da Concorrência; a lógica da intervenção passou por implementar o que Lei mandava, mas com um desenho flexível na área fim para que o Cade pudesse se adaptar melhor às mudanças do mercado; ainda assim, havia uma percepção de que as macro conseqüências estavam mapeadas. Segundo um dos entrevistados, "o processo todo foi marcado por muita liberdade" - pois não havia um modelo de organização fechado, e os participantes foram estimulados a propor ideias às autoridades - , mas com alto grau de assimetria de informação, o que, segundo o mesmo entrevistado, "tornou o processo bem menos tranquilo". É importante notar que não houve contratação de consultoria; os servidores que lideraram o processo, e agiram com pouco embasamento teórico e muito mais empírico.

A parte da diretoria administrativa, especialmente, ficou bastante relegada, tanto que alguns entrevistados apontam que a mudança na área meio ainda não havia acabado à época das entrevistas.

\subsubsection{Resultados esperados e percebidos}

A principal expectativa, segundo o ex-Secretário, era a de que o pacote básico de intervenções funcionasse. Mais especificamente, esperava-se: (i) uma sede funcional; (ii) organograma aprovado e equipes formadas tempestivamente, para evitar que o Cade ficasse sem capacidade institucional uma vez em vigor a Lei e o novo Decreto de Estrutura; (iii) Regimento interno aprovado; (iv) fluxo de trabalho de AC adequadamente estruturado; (v) pessoas 
engajadas, conscientes de seu papel no processo de transição e trabalhando para melhorar os resultados do Cade; e (vi) sistema de tramitação processual compatível com a nova realidade. Segundo a avaliação do ex-Secretário, apenas o objetivo vi não foi atingido na época da mudança. Os principais resultados esperados a médio/longo prazo eram um tempo menor de tramitação dos processos de Ato de Concentração - redução do tempo médio registrado caiu de 151 dias para 25 (ENAP, 2014), uma maior capacidade de processamento de processos administrativos e diminuição do estoque de casos a serem instruídos e/ou julgados no Cade.

Em termos de resultados esperados, havia uma expectativa de reconhecimento da área meio do Cade em virtude da ampliação do quadro de cargos, expectativa essa que não foi atendida, na percepção de um dos entrevistados. Outra expectativa forte era a ampliação do quadro do Cade (que já era considerado deficitário à época), expectativa essa também frustrada. Segundo um dos entrevistados, o foco foi muito dado na área fim, com o objetivo de manter a reputação do Cade e surpreender positivamente os apoiadores da mudança. Não houve muita preocupação com a área meio, "era esperado que eles se virassem e cumprissem o que tinha que ser feito".

\subsubsection{Fatores que facilitaram e dificultaram o processo}

A principal dificuldade relatada foi a falta de recursos generalizada: "falta de gente, falta de dinheiro, falta de pessoal com dedicação exclusiva pra mudança, falta de mão de obra especializada para uma serie de trabalhos que não eram core do Cade, mas que eram necessários, tais como arquitetos e engenheiros para criar o leiaute da nova sede." A dependência do Ministério da Justiça e do Ministério do Planejamento também foram fatores que contribuíram negativamente. Além disso, o modelo de governança anterior (com três agências governamentais executando o mesmo processo) não favorecia a liderança da mudança. $\mathrm{O}$ alto nível de ansiedade do setor privado também foi um dificultador, pois sugou muitos recursos, exigiu uma forte gestão de comunicação e trouxe um início de novo Cade um pouco conturbado para os servidores, com a notificação em massa de Atos de Concentração no primeiro mês de funcionamento do Cade.

Um obstáculo que trouxe alguma ansiedade para o processo era a falta de definição da equipe, inclusive de quem seriam o Presidente e o Superintendente. Isso gerou na equipe muita ansiedade e incerteza sobre o futuro pois, até um mês antes da entrada em vigor da Lei, não se 
sabia se as pessoas que estavam liderando o processo seriam as que permaneceriam. A alta dependência de atores externos, tais como o Ministério do Planejamento, para obter ampliação dos quadros do Cade, por exemplo, também foi apontado como um dificultador.

Como fatores facilitadores, foi apontado primeiramente o alto nível de comprometimento das pessoas com o projeto: "pessoas que queriam participar do projeto de graça", "união das pessoas do Cade antigo", "servidores engajados e competentes". Um segundo elemento foi a qualidade do corpo técnico, considerando-se que foram os servidores do órgão que formularam e executaram o plano. $\mathrm{O}$ acesso a participação em fóruns internacionais e abertura de acesso a boas práticas também foram diferenciais. Por fim, menciona-se a capacidade de formular parcerias e a abertura com pessoas estratégicas, como o Ministro da Justiça, como fatores institucionais importantes

\subsubsection{Reações verificadas}

Os entrevistados relataram a percepção de engajamento e empolgação com a mudança, tanto no Cade quanto na SDE. As causas dessa empolgação vinham da percepção de que o processo havia chegado finalmente ao seu fim, que o Cade se fortaleceria e que o trabalho (e o reconhecimento) das pessoas do Cade iria melhorar, de forma geral. Um dos entrevistados relatou a importância da confiança dos servidores nas lideranças do processo; havia uma percepção de que as pessoas que estavam à frente do processo eram as melhores, e de que haviam bons planejamentos a serem executados. Em síntese, havia um sentimento de que a mudança daria certo, mesmo com todos os percalços, e de mérito compartilhado entre todos os envolvidos.

No caso da SDE, havia um certo sentimento de ansiedade, em virtude do fim da secretaria e da incerteza sobre o que aconteceria com as pessoas. Os servidores da SDE ficaram mais distantes da mudança em um primeiro momento; aqueles que se envolveram nos grupos apoiaram mais a mudança do que os que ficaram mais a margem. De forma geral, foi relatado um menor engajamento dos servidores da SDE.

Com base nos relatos apresentados e na análise dos documentos indicados pelos entrevistados, sintetizou-se a lista de variáveis abaixo, utilizadas no Estudo 2:

Tabela 4

\section{Resultados mapeados a partir do Estudo 1}




\begin{tabular}{|l|l|}
\hline $\begin{array}{l}\text { Resultado } \\
\text { pereebido }\end{array}$ & Conteúdo da afirmação \\
\hline Resultado 1 & $\begin{array}{l}\text { O Cade passou a contar, a partir de maio de 2012, com novos processos de trabalho na área } \\
\text { finalística }\end{array}$ \\
\hline Resultado 2 & $\begin{array}{l}\text { O Cade passou a contar, a partir de maio de 2012, com novos processos de trabalho na área } \\
\text { de suporte }\end{array}$ \\
\hline Resultado 3 & $\begin{array}{l}\text { O Cade passou a contar, a partir de maio de 2012, com um novo processo de análise de atos } \\
\text { de concentração. Agora, as empresas têm de comunicar uma fusão antes da conclusão do } \\
\text { negócio. }\end{array}$ \\
\hline Resultado 4 & $\begin{array}{l}\text { Os prazos processuais mudaram após o processo de mudança organizacional iniciado em maio } \\
\text { de 2012, e isso diminuiu o tempo que se leva para analisar um Ato de Concentração (fusão e } \\
\text { aquisição entre empresas) }\end{array}$ \\
\hline Resultado 5 & $\begin{array}{l}\text { Os prazos processuais mudaram após o processo de mudança organizacional iniciado em maio } \\
\text { de 2012, e isso diminuiu o tempo que se leva para analisar um processo punitivo (processo de } \\
\text { análise de uma conduta unilateral anticompetitiva ou de um cartel) }\end{array}$ \\
\hline Resultado 6 & $\begin{array}{l}\text { O Cade possui uma nova estrutura organizacional. Essa nova estrutura mudou as } \\
\text { responsabilidades e as demandas da área em que eu trabalho }\end{array}$ \\
\hline Resultado 7 & $\begin{array}{l}\text { O Cade possui uma nova estrutura organizacional. Essa nova estrutura demandou a mudança } \\
\text { na forma como as áreas trabalham. }\end{array}$ \\
\hline Resultado 8 & $\begin{array}{l}\text { As incorporação de novas atribuições e novos processos de trabalho na área fim repercutiram } \\
\text { nas áreas de suporte. }\end{array}$ \\
\hline Resultado 9 & $\begin{array}{l}\text { As áreas de suporte possuem novas responsabilidades e formas de trabalho por conta das } \\
\text { alterações ocorridas na área fim. }\end{array}$ \\
\hline Resultado 10 & $\begin{array}{l}\text { A nova estrutura organizacional do Cade permitiu a melhoria dos seus resultados } \\
\text { organizacionais. }\end{array}$ \\
\hline Resultado 11 & As pessoas têm menos disposição para cooperar na solução de problemas hoje. \\
\hline Resultado 12 & As unidades do Cade são mais distantes uma das outras do que antes da mudança. \\
\hline
\end{tabular}

Fonte: Elaborado pela autora.

\subsubsection{Análise das escalas}

Nesse item, serão apresentados os resultados das análises exploratória das variáveis formadoras das escalas de aderência à mudança e componentes da estrutura organizacional e das análises fatoriais exploratórias.

Procedendo à análise exploratória, o primeiro aspecto analisado do conjunto de dados foi a normalidade das variáveis métricas. Para essa passo, utilizaram-se o teste de KolmogorovSmirnov (teste KS) e a análise dos índices de assimetria e curtose e dos histogramas de cada variável. O teste KS apontou que todos os itens tanto da escala de Aderência à Mudança quanto a de Componentes da Estrutura Organizacional eram significativamente diferentes de uma distribuição normal. A análise dos índices de assimetria e curtose, em conjunto com a análise gráfica dos histogramas, indicou que há grande assimetria negativa em todas as variáveis da escala de aderência à mudança e em grande parte das variáveis da escala de componentes da 
estrutura organizacional, ou seja, os dados estão concentrados na cauda direita das variáveis. Diante desse cenário, as variáveis foram padronizadas para se comparar as soluções obtidas, uma vez que, segundo Tabachnick e Fidell (2007), soluções com dados padronizados podem ser superiores (ainda que, em uma análise exploratória, o pressuposto da normalidade não seja imperativo). Após a comparação entre os dados brutos e os padronizados, percebeu-se que não havia melhora significativa; por isso, as análises foram realizadas com os dados brutos, uma vez que o pressuposto da normalidade não é necessário para a utilização da regressão logística.

Em seguida, procedeu-se a realização das análises com os outliers e sem os outliers. Os resultados obtidos com os outliers foram ligeiramente melhores; por isso, optou-se por utilizar o banco de dados com os casos extremos inseridos. Os casos omissos foram excluídos caso a caso (método pairwise).

Para as análises fatoriais, empregou-se o método de análise dos componentes principais (princial axis factoring). Foram investigadas a fatorabilidade dos dados (por meio do índice KMO - Kaiser-Meyer-Olkin), a consistência interna dos fatores e, por fim, foram geradas novas variáveis com base na composição de fatores da melhor solução por meio das médias das variáveis de cada fator.

\section{A) Escala de Aderência à Mudança}

O primeiro passo da análise fatorial foi a solicitação de solução inicial, com a obtenção da medida KMO, da matriz de correlação, da variância total explicada e das cargas fatoriais. A medida de consistência interna (no caso, a adotada foi o alpha de Cronbach) foi calculada para cada solução. Como critério estatístico para a seleção do número de fatores, considerou-se a ocorrência de autovalores (Eigenvalues) maiores do que 1, conforme indicam Hair et al (2009) e Tabachnick e Fidell (2007), e o exame do scree plot como método gráfico complementar. O critério para manutenção de itens foi o de cargas fatoriais acima de 0,32 , conforme recomendam Tabachnick e Fidell (2007).

O KMO encontrado foi de 0,871, o que, segundo Hair et al. (2009) indica uma solução excelente. A solução inicial não rotacionada indicava a existência de 3 (baseados nos autovalores) a 4 fatores (baseado no scree plot). O passo seguinte foi aplicar a rotação oblíqua (direct oblimin) e forçar uma solução com 4, 3, 2 e 1 fator. A rotação obliqua aplica-se a situações em que há possível correlação entre os fatores, o que é coerente com a literatura sobre formação de atitudes (Rodrigues et 
al, 2009) e também com os estudos empíricos encontrados na revisão de literatura desse trabalho (Neiva, 2004; Pantoja e Neiva, 2011; Voet, 2009 e outros).

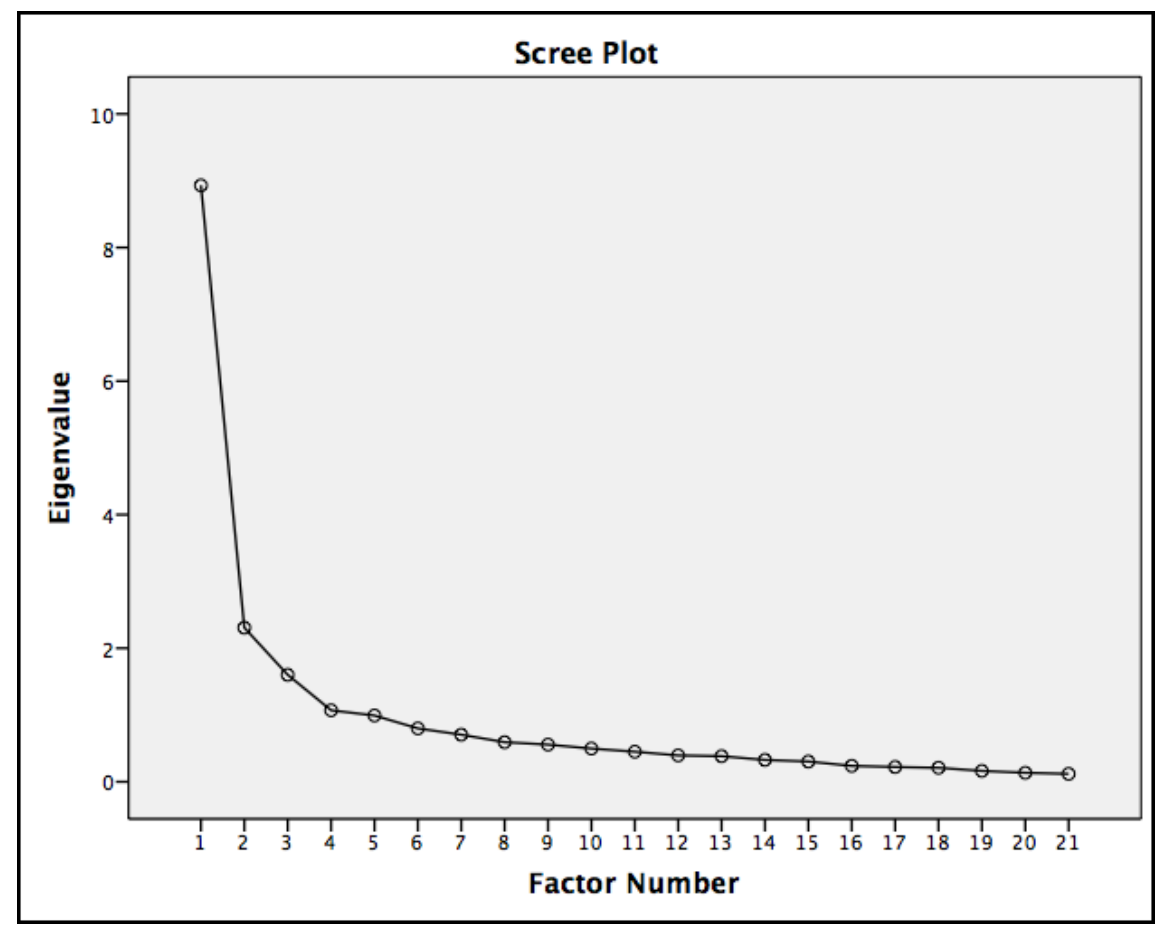

\section{Figura 5. Scree plot}

Fonte: elaborada pela autora

A melhor solução encontrada foi a unifatorial, com cargas fatoriais variando de 0,501 a 0,743 com alta taxa de confiabilidade (alphas de Cronbach de 0,929), com um total de $42 \%$ da variância cumulada explicada. A tabela 6 apresenta a solução final com as cargas fatoriais e as comunalidades após a extração. Ressalta-se que nenhum item foi descartado, pois todos tiveram carga maior do que 0,32. Alguns itens apresentaram comunalidades baixas, o que pode indicar que esses itens possuem baixa relação com os itens dos fatores, podendo tratar-se de outro constructo, por exemplo.

\section{Tabela 5}

\section{Análise fatorial da escala de Aderência à Mudança.}




\begin{tabular}{|c|c|c|}
\hline Item & Carga fatorial & Comunalidades \\
\hline A mudança despertou emoções positivas em mim & 0,725 & 0,468 \\
\hline A mudança contribuiu para a melhoria do resultado da atuação do Cade & 0,706 & 0,499 \\
\hline Senti-me motivado com a mudança dada sua implementação no Novo Cade. & 0,706 & 0,297 \\
\hline $\begin{array}{l}\text { O Cade preocupou-se em planejar as pessoas para a mudança que iria } \\
\text { acontecer }\end{array}$ & 0,684 & 0,468 \\
\hline As principais mudanças que foram implementadas estavam claras para mim. & 0,675 & 0,456 \\
\hline As pessoas aqui no Cade reagiram bem à mudança & 0,668 & 0,446 \\
\hline As informações sobre a mudança foram comunicadas a contento. & 0,663 & 0,440 \\
\hline As pessoas a minha volta estavam motivadas para mudar & 0,662 & 0,438 \\
\hline Acredito que a mudança beneficiou o Cade como um todo & 0,637 & 0,406 \\
\hline $\begin{array}{l}\text { As pessoas à minha volta fizeram o que estava ao alcance delas para } \\
\text { garantir a implementação do Novo Cade }\end{array}$ & 0,624 & 0,389 \\
\hline A implementação da mudança apresentada foi necessária para o Cade & 0,608 & 0,369 \\
\hline $\begin{array}{l}\text { Eu empreendi esforços para atingir os resultados esperados do processo de } \\
\text { mudança no Cade }\end{array}$ & 0,605 & 0,366 \\
\hline $\begin{array}{l}\text { Eu fiz o que estava ao meu alcance para garantir o sucesso da } \\
\text { implementação do Novo Cade }\end{array}$ & 0,599 & 0,359 \\
\hline $\begin{array}{l}\text { O engajamento das pessoas da minha unidade foi importante para a } \\
\text { implementação do Novo Cade }\end{array}$ & 0,588 & 0,346 \\
\hline $\begin{array}{l}\text { Eu procurei convencer os outros dos benefícios das mudanças } \\
\text { implementadas no Cade }\end{array}$ & 0,564 & 0,318 \\
\hline A implementação da mudança contou com a participação de todo o Cade & 0,557 & 0,310 \\
\hline O meu engajamento foi importante para a implementação do Novo Cade & 0,556 & 0,309 \\
\hline $\begin{array}{l}\text { Eu agi no sentido de reduzir a resistência das outras pessoas em relação às } \\
\text { mudanças no Cade }\end{array}$ & 0,55 & 0,303 \\
\hline $\begin{array}{l}\text { Eu sabia do resultado esperado antes mesmo da mudança ser iniciada no } \\
\text { Cade }\end{array}$ & 0,545 & 0,297 \\
\hline
\end{tabular}




\begin{tabular}{|l|l|l|}
\hline \multicolumn{1}{|c|}{ Item } & \multicolumn{2}{|l|}{ Carga fatorial Comunalidades } \\
\hline A mudança afetou o Cade como um todo. & 0,501 & 0,251 \\
\hline
\end{tabular}

Fonte: Elaborada pela autora

\section{b) Escala de Componentes da Estrutura Organizacional}

A análise da escala de componentes da estrutura organizacional teve como objetivo verificar as dimensões latentes representadas. Não foi possível proceder a validação da escala, pois o numero de observações obtidas $(\mathrm{N}=177)$ não alcançou o mínimo necessário de 5 observações por item, conforme indicado por Pasquali (2005). Dessa forma, registrou-se apenas a estrutura adotada para a inserção da variável nas regressões logísticas.

O primeiro fator identificado possui itens que versam sobre suporte organizacional à realização de tarefas, percepção a respeito de tomada de decisão e trabalho em equipe e um item sobre comunicação organizacional. Dessa forma, nomeou-se esse fator como Sistema de decisões e suporte organizacional. Esse fator foi formado por 17 itens.

O segundo fator é composto por itens que tratam de aspectos formais sobre a formalização da atribuição e definição de tarefas, hierarquia e sistemas de comunicação, e um fator de suporte organizacional. Dessa forma, esse fator foi denominado Sistema de Comunicação e Percepção sobre Aspectos Formais, e foi formado por 9 itens.

O terceiro fator versa sobre a percepção sobre a chefia e as interações em equipe que contribuem para o desempenho individual e organizacional. Dessa forma, esse fator foi denominado Percepção sobre a chefia e a equipe, é composto por 5 itens.

Por fim, o último fator identificado trata sobre a percepção da existência e da influência de lideranças informais na organização. Esse fator é composto de apenas 3 itens, e foi denominado Percepção de Autoridade Informal. 


\subsection{Modelos empíricos}

Nesse item, serão testadas as relações hipotetizadas na seção 3 deste trabalho. Para tal, será utilizada a técnica de regressão logística e, em seguida, teste não paramétrico para verificação de uma possível diferença estatisticamente significante para a formação da aderência à mudança entre determinados grupos.

\subsubsection{Modelos empíricos reduzidos}

Segundo Tabachnick e Fidell (2007), a regressão logística responde aos mesmos tipos de questão que a análise discriminante e a regressão múltipla com uma variável dependente dicotômica; porém, a técnica é mais flexível do que as citadas, uma vez que não possui como pressupostos a normalidade das variáveis envolvidas, a linearidade entre elas (em verdade, o seu uso é particularmente indicado quando não se espera uma relação linear) ou o uso exclusivo de preditores contínuos.

A regressão logística, assim como a regressão múltipla, pode ser hierarquia ou estatística (stepwise). Segundo Abbad e Torres (2002), o uso da regressão hierárquica é mais adequado em estudos confirmatórios das relações descritas em modelos teóricos consistentes. Esses modelos foram testados empiricamente, mas ainda carecem de validação; nesses casos, a ordem de entrada das variáveis é definida pelo pesquisador, com base em teoria ou pesquisas anteriores. Ainda segundo os autores, no caso da regressão stepwise, o pesquisador hipotetiza relações entre as variáveis, criando um modelo, mas sem afirmações consistentes sobre direção e magnitude relações. Ao contrário da regressão hierárquia, a stepwise trata de análise de exploratória, uma vez que esses estudos ainda não encontram apoio empírico às hipóteses a serem testadas.

Para investigar as relações empíricas entre as variáveis, foram elaborados inicialmente 12 modelos de regressão logística, tendo os resultados mapeados na primeira etapa desse estudo como variáveis critério, e as variáveis pessoais e profissionais, os fatores componentes da estrutura organizacional e a variável aderência à mudança como variável independente. As relações empíricas investigadas foram as seguintes:

- H1 - aderência à mudança está positivamente relacionada com os resultados percebidos pelos funcionários da organização. 
- H2: os componentes da estrutura organizacional influenciarão na relação entre aderência à mudança e percepção de mudança organizacional.

- H3: haverá diferenças estatisticamente significativas na formação da aderência à mudança entre os grupos das áreas fim e meio.

Para o teste da hipótese 2, utilizou-se o conceito de moderação. Tabachnick e Fidell (2007) definem moderação como a variação do coeficiente de regressão, ou a importância, de um preditor em função da variação de um outro preditor. Segundo Abbad e Torres (2002), para verificar a moderação, deve-se observar a interação entre as três variáveis envolvidas. Primeiramente, verifica-se se A é um bom preditor de C e, em seguida, se A e B e a interação entre A e B predizem C. Caso a interação seja uma preditoras estatisticamente significante de C, diz-se que B é moderadora da relação entre A e C, podendo esta relação restar fortalecida ou diminuída (dependendo do valor de B). Neste trabalho, a variável aderência á mudança representa o papel de A, a variável resultados percebidos em cada modelo de regressão representa o papel de C, e a variável componentes da estrutura organizacional representa o papel de B.

Adicionalmente, foi criado um $13^{\circ}$ modelo, com a criação de uma nova variável dependente derivada das outras 12 variáveis dependentes, com o objetivo de sintetizar os resultados do Estudo 2 em um modelo empírico. Primeiramente, foram calculadas as frequências para cada caso e, depois, aqueles sujeitos que se encontravam no primeiro e segundo quartis foram recodificados como "baixa percepção de resultados", e os presentes nos terceiro e quarto quartis, foram recodificados como "alta percepção de resultados", conforme feito por Silva (2011) em tese de doutorado em que foi utilizada a regressão logística. Os mesmos testes foram realizados, de forma a verificar as hipóteses 1 e 2 desse estudo em relação a um modelo agregado. A freqüência observada para os resultados 1 a 12 indica que, de forma geral, todos os resultados mapeados foram fortemente identificados pelos sujeitos, conforme Tabela 6 abaixo.

Tabela 6

\section{Freqüências de resultados percebidos}

\begin{tabular}{|l|l|l|}
\hline $\begin{array}{c}\text { Resultado } \\
\text { mapeado }\end{array}$ & \multicolumn{1}{|c|}{ Conteúdo da afirmação } & \multicolumn{1}{|c|}{$\begin{array}{c}\text { Percentual (dos casos } \\
\text { válidos) }\end{array}$} \\
\hline $\begin{array}{l}\text { Resultado } \\
1\end{array}$ & $\begin{array}{l}\text { O Cade passou a contar, a partir de maio de 2012, com novos } \\
\text { processos de trabalho na área finalística }\end{array}$ & $\begin{array}{l}\text { Sim= } 96 \% \\
\mathrm{Não}=4 \%\end{array}$ \\
\hline Resultado & O Cade passou a contar, a partir de maio de 2012, com novos & $\mathrm{Sim}=93,1 \%$ \\
\hline
\end{tabular}




\begin{tabular}{|c|c|c|}
\hline $\begin{array}{l}\text { Resultado } \\
\text { mapeado }\end{array}$ & Conteúdo da afirmação & $\begin{array}{l}\text { Percentual (dos casos } \\
\text { válidos) }\end{array}$ \\
\hline 2 & processos de trabalho na área de suporte & Não $=6,9 \%$ \\
\hline $\begin{array}{l}\text { Resultado } \\
3\end{array}$ & $\begin{array}{l}\text { O Cade passou a contar, a partir de maio de 2012, com um novo } \\
\text { processo de análise de atos de concentração. Agora, as } \\
\text { empresas têm de comunicar uma fusão antes da conclusão do } \\
\text { negócio. }\end{array}$ & $\begin{array}{l}\text { Sim }=96,6 \% \\
\text { Não }=3,4 \%\end{array}$ \\
\hline $\begin{array}{l}\text { Resultado } \\
4\end{array}$ & $\begin{array}{l}\text { Os prazos processuais mudaram após o processo de mudança } \\
\text { organizacional iniciado em maio de 2012, e isso diminuiu o } \\
\text { tempo que se leva para analisar um Ato de Concentração (fusão } \\
\text { e aquisição entre empresas) }\end{array}$ & $\begin{array}{l}\text { Sim }=99,4 \% \\
\text { Não }=0,6 \%\end{array}$ \\
\hline $\begin{array}{l}\text { Resultado } \\
5\end{array}$ & $\begin{array}{l}\text { Os prazos processuais mudaram após o processo de mudança } \\
\text { organizacional iniciado em maio de 2012, e isso diminuiu o } \\
\text { tempo que se leva para analisar um processo punitivo (processo } \\
\text { de análise de uma conduta unilateral anticompetitiva ou de um } \\
\text { cartel) }\end{array}$ & $\begin{array}{l}\text { Sim }=78,2 \% \% \\
\text { Não }=21,8 \%\end{array}$ \\
\hline $\begin{array}{l}\text { Resultado } \\
6\end{array}$ & $\begin{array}{l}\text { O Cade possui uma nova estrutura organizacional. Essa nova } \\
\text { estrutura mudou as responsabilidades e as demandas da área em } \\
\text { que eu trabalho }\end{array}$ & $\begin{array}{l}\operatorname{Sim}=85,8 \% \\
\text { Não }=14,2 \%\end{array}$ \\
\hline $\begin{array}{l}\text { Resultado } \\
7\end{array}$ & $\begin{array}{l}\text { O Cade possui uma nova estrutura organizacional. Essa nova } \\
\text { estrutura demandou a mudança na forma como as áreas } \\
\text { trabalham. }\end{array}$ & $\begin{array}{l}\operatorname{Sim}=93,2 \% \\
\text { Não }=6,8 \%\end{array}$ \\
\hline $\begin{array}{l}\text { Resultado } \\
8\end{array}$ & $\begin{array}{l}\text { As incorporação de novas atribuições e novos processos de } \\
\text { trabalho na área fim repercutiram nas áreas de suporte. }\end{array}$ & $\begin{array}{l}\text { Sim }=96,6 \% \\
\text { Não }=3,4 \%\end{array}$ \\
\hline $\begin{array}{l}\text { Resultado } \\
9\end{array}$ & $\begin{array}{l}\text { As áreas de suporte possuem novas responsabilidades e formas } \\
\text { de trabalho por conta das alterações ocorridas na área fim. }\end{array}$ & $\begin{array}{l}\text { Sim }=91,4 \% \\
\text { Não }=8,6 \%\end{array}$ \\
\hline $\begin{array}{l}\text { Resultado } \\
10\end{array}$ & $\begin{array}{l}\text { A nova estrutura organizacional do Cade permitiu a melhoria } \\
\text { dos seus resultados organizacionais. }\end{array}$ & $\begin{array}{l}\text { Sim }=96 \% \\
\text { Não }=4 \%\end{array}$ \\
\hline $\begin{array}{l}\text { Resultado } \\
11\end{array}$ & $\begin{array}{l}\text { As pessoas têm menos disposição para cooperar na solução de } \\
\text { problemas hoje. }\end{array}$ & $\begin{array}{l}\text { Sim }=13 \% \\
\text { Não }=87 \%\end{array}$ \\
\hline $\begin{array}{l}\text { Resultado } \\
12\end{array}$ & $\begin{array}{l}\text { As unidades do Cade são mais distantes uma das outras do que } \\
\text { antes da mudança. }\end{array}$ & $\begin{array}{l}\text { Sim }=45,8 \% \\
\text { Não }=54,2 \%\end{array}$ \\
\hline
\end{tabular}

Fonte: Elaborada pela autora

Cada um dos resultados mapeados constitui modelos empíricos reduzidos da presente pesquisa, pois abordam aspectos específicos do processo de mudança organizacional do Cade. Com o objetivo de consolidar um modelo empírico de pesquisa e oferecer uma visão global dos resultados percebidos pelos sujeitos, foi criada uma nova variável dicotômica baseada no número de resultados percebidos por cada indivíduo. A Figura 4 resume a variável criada a partir da contagem de resultados percebidos por observação, de forma a se ter um panorama geral do processo de mudança organizacional.

De forma geral, é interessante notar que a grande maioria dos participantes relatou a percepção de um número grande de resultados (9 a 11). Para os testes estatísticos, essa nova variável foi recodificada em uma variável dicotômica, cujas categorias foram baixa percepção de resultados (primeiro e segundo quartis) e alta percepção de resultados (terceiro e quarto quartis). 
O critério de quartis foi escolhido de forma a dividir a amostra exatamente ao meio, emulando procedimento realizado por Silva (2011) em sua tese de doutorado. A Figura 6 apresenta as frequências registradas na nova variável.

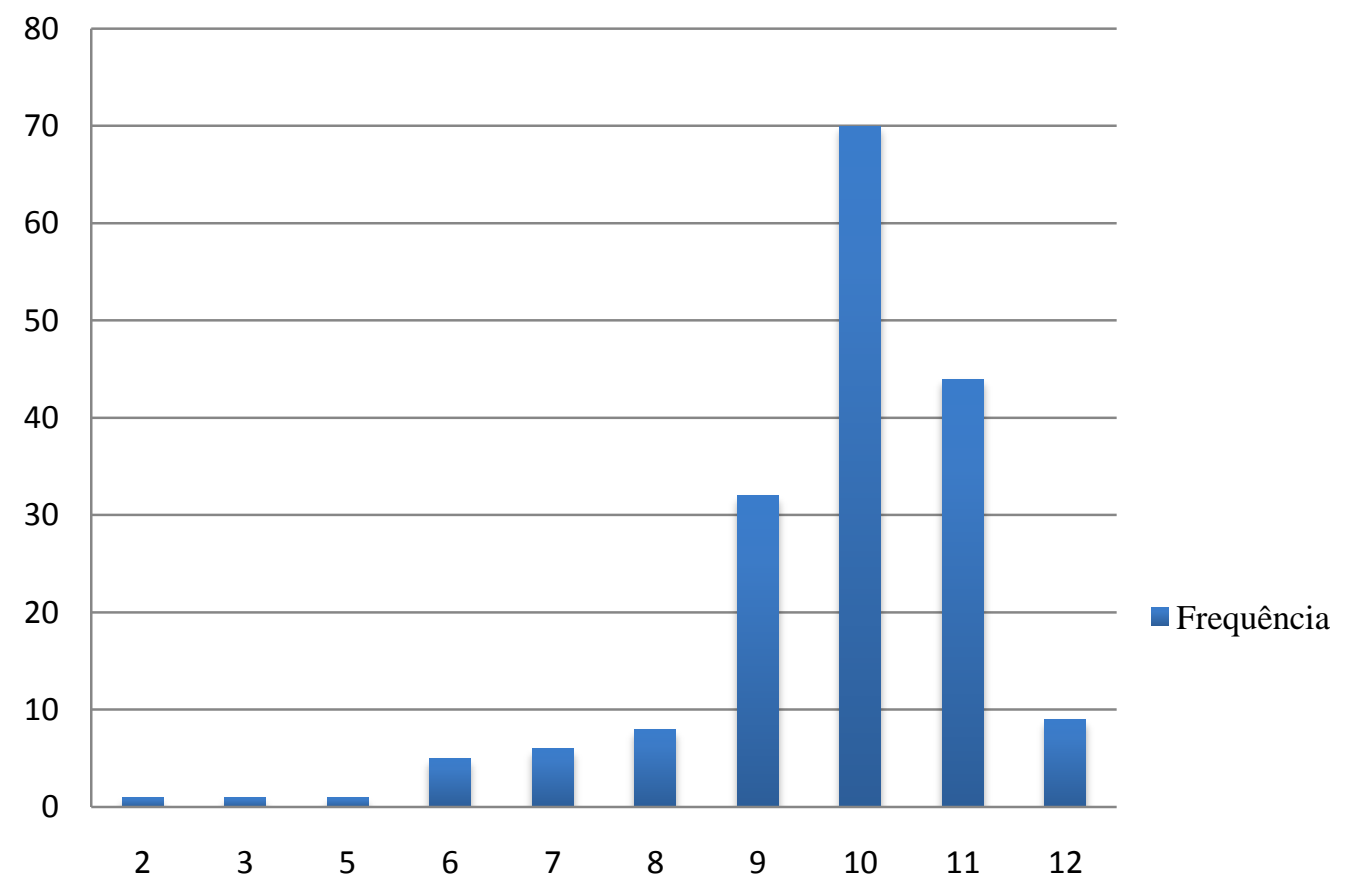

Figura 6. Frequiência agregada dos resultados percebidos por participante.

Fonte: elaborada pela autora

Os testes estatísticos foram realizados em três passos, todos com regressão stepwise forward, sendo o critério de inserção das variáveis independentes baseado na estatística Wald (equivalente ao teste $\mathrm{t}$, na regressão linear múltipla). O primeiro passo foi verificar as relações empíricas entre as variáveis dependentes em cada modelo e a variável independente aderência à mudança inserida sozinha no modelo. O objetivo desse passo foi testar a hipótese de que aderência à mudança está positivamente relacionada com os resultados efetivos percebidos pelos funcionários da organização. Os resultados apresentam que a variável aderência à mudança apresentou significância estatística em 6 das 13 regressões realizadas. Em cada tabela, foram apresentados, para os modelos em que houve significância, as estatísticas de ajuste do modelo, a razão de chance e os intervalos de confiança, bem como os níveis de significância associados. A Tabela 7 apresenta o resumo das variáveis. 
Tabela 7

\section{Regressão logística com uma variável independente.}

\begin{tabular}{|c|c|c|c|c|c|c|}
\hline $\begin{array}{l}\text { Modelo da } \\
\text { equação }\end{array}$ & $\Delta-2 \mathrm{LL}$ & $\begin{array}{l}\text { Hosmer- } \\
\text { Lemeshow }\end{array}$ & $\begin{array}{l}\text { Variáveis } \\
\text { no modelo }\end{array}$ & $\operatorname{Exp}(B)$ & I.C (95\%) & $\begin{array}{c}\mathbf{R}^{2} \text { de } \\
\text { Nagelkerke }\end{array}$ \\
\hline Modelo 1 & $8,585^{* *}$ & 0,748 & $\begin{array}{l}\text { Aderência à } \\
\text { mudança }\end{array}$ & $2,12 * *$ & 1,248 a 3,600 & 0,167 \\
\hline Modelo 2 & $5,067 *$ & 0,764 & $\begin{array}{l}\text { Aderência à } \\
\text { mudança }\end{array}$ & $1,561^{*}$ & 1,060 a 2,298 & 0,073 \\
\hline Modelo 3 & \multicolumn{6}{|c|}{ Não houve significância } \\
\hline Modelo 4 & \multicolumn{6}{|c|}{ Não houve significância } \\
\hline Modelo 5 & \multicolumn{6}{|c|}{ Não houve significância } \\
\hline Modelo 6 & $7.308^{*}$ & $0,079 *$ & $\begin{array}{l}\text { Aderência à } \\
\text { mudança }\end{array}$ & $1,487 * *$ & 1,113 a 1,986 & 0,073 \\
\hline Modelo 7 & \multicolumn{6}{|c|}{ Não houve significância } \\
\hline Modelo 8 & \multicolumn{6}{|c|}{ Não houve significância } \\
\hline Modelo 9 & $\begin{array}{c}10,572 * \\
* *\end{array}$ & 0,948 & $\begin{array}{l}\text { Aderência à } \\
\text { mudança }\end{array}$ & $1,811 * *$ & 1,252 a 2,618 & 0,133 \\
\hline Modelo 10 & \multicolumn{6}{|c|}{ Não houve significância } \\
\hline Modelo 11 & $9,404 * *$ & 0,002 & $\begin{array}{c}\text { Aderência à } \\
\text { mudança }\end{array}$ & $0,627 * *$ &, 463 a ,849 & 0,096 \\
\hline Modelo 12 & \multicolumn{6}{|c|}{ Não houve significância } \\
\hline Modelo 13 & $4,777^{*}$ & 0,711 & $\begin{array}{c}\text { Aderência à } \\
\text { mudança }\end{array}$ & $1,267 *$ & 1,021 a 1,573 & 0,036 \\
\hline
\end{tabular}

Nota: ${ }^{*} \mathrm{p}<0,05 ; * * \mathrm{p}<0,01 ; * * * \mathrm{p}<0,001$

Fonte: Elaborada pela autora

O Modelo 11 apresentou uma estatística de Hosmer-Lemeshow ruim, o que pode indicar um ajuste ruim do modelo aos dados, ainda que haja redução no log de verossimilhança significativo.

O segundo passo foi o teste das variáveis pessoais e profissionais em conjunto com a variável aderência à mudança, todas inseridas ao mesmo tempo na regressão logística. As variáveis introduzidas nesse passo foram: gênero, idade, tempo de serviço, lotação e vínculo funcional. Além dessas, foram incluídas outras variáveis de controle, tais como se o respondente participou da mudança ou não, se é ex-funcionário do Cade e se pertence à área meio ou fim. Para a análise, as variáveis categóricas foram codificadas em variáveis dummy. Ao realizar a 
regressão stepwise, alguns modelos obtiveram variáveis com significância estatística em mais de um passo; nesses casos, a sequiência de passos estão descritas na coluna "Etapa do modelo". Os resultados estão relatados na Tabela 8 .

Tabela 8

Regressão logística variáveis pessoais, profissionais e aderência à mudança.

\begin{tabular}{|c|c|c|c|c|c|c|c|}
\hline $\begin{array}{l}\text { Modelo } \\
\text { da } \\
\text { equação }\end{array}$ & $\begin{array}{l}\text { Etapas } \\
\text { do } \\
\text { modelo }\end{array}$ & $\Delta-2 \mathrm{LL}$ & $\begin{array}{c}\text { Hosmer- } \\
\text { Lemeshow }\end{array}$ & $\begin{array}{l}\text { Variáveis no } \\
\text { modelo }\end{array}$ & $\operatorname{Exp}(B)$ & I.C (95\%) & $\begin{array}{c}\mathbf{R}^{2} \text { de } \\
\text { Nagelkerke }\end{array}$ \\
\hline Modelo 1 & I &, $140 * *$ & 0,701 & $\begin{array}{l}\text { Aderência á } \\
\text { mudança }\end{array}$ & $2,097 * *$ & 1,232 a 3,570 & 0,163 \\
\hline Modelo 2 & I &, $457^{*}$ & 0,95 & $\begin{array}{l}\text { Aderência á } \\
\text { mudança }\end{array}$ & $1,537 *$ & 1,042 a 2,269 & 0,068 \\
\hline Modelo 3 & I & \multicolumn{6}{|c|}{ Não houve significância } \\
\hline Modelo 4 & I & \multicolumn{6}{|c|}{ Não houve significância } \\
\hline Modelo 5 & I & \multicolumn{6}{|c|}{ Não houve significância } \\
\hline \multirow[t]{3}{*}{ Modelo 6} & I & $4,099 * *$ & 0,721 & $\begin{array}{c}\text { Sistema de } \\
\text { decisões e } \\
\text { suporte } \\
\text { organizacional }\end{array}$ & $1,589 * *$ & 1,188 a 2,125 & 0,103 \\
\hline & & $\begin{array}{c}17,175^{*} \\
*\end{array}$ & 0,85 & $\begin{array}{l}\text { Participou na } \\
\text { mudança }\end{array}$ & $3,48 * *$ & 1,387 a 8,733 & 0,173 \\
\hline & II & & & $\begin{array}{c}\text { Sistema de } \\
\text { decisões e } \\
\text { suporte } \\
\text { organizacional }\end{array}$ & $1,556^{* *}$ & 1,158 a 2,091 & \\
\hline Modelo 7 & I & \multicolumn{6}{|c|}{ Não houve significância } \\
\hline Modelo 8 & I & \multicolumn{6}{|c|}{ Não houve significância } \\
\hline Modelo 9 & I & $\begin{array}{c}10,047 * \\
*\end{array}$ & 0,955 & $\begin{array}{c}\text { Aderência á } \\
\text { mudança }\end{array}$ & $1,79 * *$ & 1,236 a 2,592 & 0,128 \\
\hline $\begin{array}{c}\text { Modelo } \\
10\end{array}$ & I & $8,598 * *$ & 0,756 & $\begin{array}{c}\text { Sistema de } \\
\text { Comunicação e } \\
\text { Percepção sobre } \\
\text { Aspectos } \\
\text { Formais }\end{array}$ & $2,144 * *$ & 1,282 a 3,586 & 0,17 \\
\hline $\begin{array}{c}\text { Modelo } \\
11\end{array}$ & I & $\begin{array}{c}11,250 * \\
*\end{array}$ & 0,012 & $\begin{array}{l}\text { Aderência à } \\
\text { mudança }\end{array}$ & $0,591 * *$ &, 430 a ,810 & 0,119 \\
\hline $\begin{array}{l}\text { Modelo } \\
12\end{array}$ & I & $6,569 * *$ & $\begin{array}{c}\text { não foi } \\
\text { calculado }\end{array}$ & Gênero & $2,215^{*}$ & 1,198 a 4,096 & 0,05 \\
\hline
\end{tabular}




\begin{tabular}{|c|c|c|c|c|c|c|c|}
\hline $\begin{array}{c}\text { Modelo } \\
\text { da } \\
\text { equação }\end{array}$ & $\begin{array}{c}\text { Etapas } \\
\text { do } \\
\text { modelo }\end{array}$ & $\Delta-2 \mathrm{LL}$ & $\begin{array}{c}\text { Hosmer- } \\
\text { Lemeshow }\end{array}$ & $\begin{array}{l}\text { Variáveis no } \\
\text { modelo }\end{array}$ & $\operatorname{Exp}(B)$ & I.C $(95 \%)$ & $\begin{array}{c}\mathbf{R}^{2} \text { de } \\
\text { Nagelkerke }\end{array}$ \\
\hline & \multirow[b]{2}{*}{ II } & \multirow[t]{2}{*}{$12,456^{*}$} & \multirow[t]{2}{*}{0,201} & Gênero & $2,395^{* *}$ & 1,274 a 4,503 & \multirow[t]{2}{*}{0,094} \\
\hline & & & & $\begin{array}{l}\text { Participou na } \\
\text { mudança }\end{array}$ & $0,432 *$ & 0,216 a 0,863 & \\
\hline & \multirow{3}{*}{ III } & \multirow[t]{3}{*}{$\begin{array}{c}34,729 * \\
* *\end{array}$} & \multirow[t]{3}{*}{0,178} & Gênero & $2,552 * *$ & 1,271 a 5,122 & \multirow[t]{3}{*}{0,246} \\
\hline & & & & $\begin{array}{l}\text { Vínculo } \\
\text { funcional }\end{array}$ & $\begin{array}{c}000 \mathrm{a} \\
4,061^{*}\end{array}$ & - & \\
\hline & & & & $\begin{array}{l}\text { Participou na } \\
\text { mudança }\end{array}$ & $0,325^{* *}$ & 0,141 a 0,749 & \\
\hline & \multirow{4}{*}{ IV } & \multirow{4}{*}{$\begin{array}{c}46,925 * \\
* *\end{array}$} & \multirow[t]{4}{*}{0,137} & Gênero & $3,254 * *$ & 1,535 a 6,879 & \multirow[t]{4}{*}{0,321} \\
\hline & & & & $\begin{array}{c}\text { Tempo de } \\
\text { serviço (10 anos } \\
\text { ou mais) }\end{array}$ & $7,517 * *$ & $\begin{array}{l}1,626 \mathrm{a} \\
34,762\end{array}$ & \\
\hline & & & & $\begin{array}{l}\text { Vínculo } \\
\text { funcional }\end{array}$ & $\begin{array}{l}0,135 \mathrm{a} \\
3,838^{*}\end{array}$ & - & \\
\hline & & & & $\begin{array}{l}\text { Participou da } \\
\text { mudança }\end{array}$ & $0,269^{*}$ & 0,089 a 0,815 & \\
\hline \multirow[t]{3}{*}{$\begin{array}{c}\text { Modelo } \\
13\end{array}$} & I & $\begin{array}{c}23,450 * \\
* *\end{array}$ & $\begin{array}{c}\text { Não } \\
\text { calculado }\end{array}$ & $\begin{array}{c}\text { Ocupa cargo de } \\
\text { chefia }\end{array}$ & $5,265^{* * *}$ & $\begin{array}{c}2,581 \mathrm{a} \\
10,743\end{array}$ & 0,171 \\
\hline & II & $\begin{array}{c}35,831 * \\
* *\end{array}$ & 0,974 & $\begin{array}{c}\text { Ocupa cargo de } \\
\text { chefia }\end{array}$ & $4,495 * * *$ & 2,419 a 9,402 & \multirow[t]{2}{*}{0,252} \\
\hline & & & & $\begin{array}{l}\text { Participou da } \\
\text { mudança }\end{array}$ & $3,658 * *$ & 1,731 a 7,729 & \\
\hline
\end{tabular}

Nota: $* \mathrm{p}<0,05 ; * * \mathrm{p}<0,01 ; * * * \mathrm{p}<0,001$

Fonte: Elaborada pela autora

Dos treze modelos hipotéticos, três não apresentaram variáveis com significância estatística; cinco apresentaram apenas a variável "aderência à mudança" como significativa, sem qualquer outra; os modelos 6 e 10 apresentaram como variáveis significativas componentes da estrutura organizacional (Sistema de decisões e suporte organizacional e Sistema de Comunicação e Percepção sobre Aspectos Formais, respectivamente), e o modelo 12 apresentou o maior número de variáveis preditivas, todas elas como variáveis pessoal (gênero) e profissionais. Notou-se melhora na estatística de ajuste do modelo (quando se comparam os resultados obtidos para o teste de Hosmer e Lemeshow) com a introdução das outras variáveis.

Nessa etapa, a variável "aderência à mudança", quando fez parte do modelo, teve seus coeficientes variando entre 0,591 (Modelo 11) a 2,097 (Modelo 1). A variável parece relacionarse com a percepção de resultados que, de alguma forma, possuem conteúdo positivo sobre a 
mudança; no caso em que o resultado descrito era negativo (Resultado 11: as pessoas têm menos disposição para cooperar na solução de problemas hoje), os que apresentaram índices mais altos de aderência à mudança tiveram uma chance menor de perceber esse resultado. Esse resultado é coerente com uma corrente mais recente da psicologia organizacional que investiga o efeito de construtos formulados com um enquadramento positivo sobre os fenômenos organizacionais (Armstrong-Stassen \& Schlosser, 2008; Weiner, 2009). O efeito da variável, medido em termos do $\mathrm{R}^{2}$ de Nagelkerke, variou entre $6 \%$ a $16 \%$ da variância explicada.

O Modelo 13, que buscou apresentar uma medida resumo de todos os resultados percebidos, teve como variáveis preditoras se o sujeito ocupava cargo de chefia e, na segunda etapa da estimação, se o sujeito era servidor do Cade à época da mudança (participou da mudança ou não).

Os modelos 6 (O Cade possui uma nova estrutura organizacional. Essa nova estrutura mudou as responsabilidades e as demandas da área em que eu trabalho) e 10 (A nova estrutura organizacional do Cade permitiu a melhoria dos seus resultados organizacionais) tratam de mudanças na estrutura organizacional e sua relação com novas responsabilidades e percepção de desempenho. Os dois fatores da variável "componentes da estrutura organizacional” relacionaram positivamente com a percepção do resultado; no modelo 6 , há 1,5 chance de perceber a ocorrência desse resultado, e no modelo 10, duas vezes mais chances de perceber esse resultado. Esse resultado pode dever-se ao fato de que ambos os resultados tratam sobre a estrutura formal da organização, um dos primeiros componentes da estrutura organizacional descritos.

É interessante notar que o Resultado 12 foi o que obteve maior variabilidade de respostas na variável critério, conforme apresentado na Tabela 11. No caso do modelo 12, em que aparece a variável gênero, os coeficientes representam a chance que uma pessoa do sexo masculino tem de perceber a ocorrência do resultado 12. Dessa forma, no primeiro passo do modelo, homens tem duas vezes mais chances de perceber as unidades do Cade mais distantes uma das outras. No caso da variável "participou da mudança", o coeficiente abaixo de 1 é interpretado como uma diminuição da chance; dessa forma, aquelas pessoas que participaram da mudança tem uma probabilidade menor de perceber um distanciamento das unidades do Cade.

A variável "vínculo funcional" apareceu no modelo como significativa $(\mathrm{p}=0,035)$, porém suas categorias não apresentaram significância estatística $(\mathrm{p}<0,05)$. Ainda assim, é interessante 
notar que os ocupantes do cargo de apoio administrativo $[\operatorname{Exp}(B)=4,061]$ e os servidores sem vínculo $[\operatorname{Exp}(B)=1,842]$ foram os que obtiveram maior probabilidade de perceber o distanciamento entre as áreas, conforme colocado no Resultado 12, no passo III; no passo 4, essa relação se manteve $[\operatorname{Exp}(B)=3,838]$. No caso da variável "tempo de serviço", os funcionários que marcaram possuírem mais de 10 anos de serviço apresentaram uma probabilidade 7 vezes maior de perceber o distanciamento entre as áreas do que funcionários com um tempo de serviço menor.

O terceiro passo foi o teste de moderação, conforme descrito por Tabachick e Fidell (2007) e Abbad e Torres (2002). Nesse passo, foram inseridos os produtos obtidos entre a variável "aderência à mudança" e os fatores obtidos da escala de componentes da estrutura organizacional.

Para tal, foram calculadas as interações entre os fatores da variável "componentes da estrutura organizacional" e "aderência à mudança" separadamente, assim como interações entre as variáveis que entraram nos modelos no passo 2. Além disso, também foram testadas eventuais moderações com as variáveis pessoais e profissionais. Os resultados estão relatados na Tabela 9.

Tabela 9

\section{Regressão logística com testes de moderação.}

\begin{tabular}{|c|c|c|c|c|c|c|c|}
\hline $\begin{array}{l}\text { Modelo } \\
\text { da } \\
\text { equação }\end{array}$ & $\begin{array}{l}\text { Etapas } \\
\text { do } \\
\text { modelo }\end{array}$ & $\Delta-2 \mathrm{LL}$ & $\begin{array}{c}\text { Hosmer- } \\
\text { Lemeshow }\end{array}$ & $\begin{array}{l}\text { Variáveis no } \\
\text { modelo }\end{array}$ & $\operatorname{Exp}(B)$ & I.C (95\%) & $\begin{array}{c}\mathbf{R}^{2} \text { de } \\
\text { Nagelkerke }\end{array}$ \\
\hline Modelo 1 & I & $\begin{array}{c}0,140 * \\
*\end{array}$ & 0,701 & $\begin{array}{l}\text { Aderência à } \\
\text { mudança }\end{array}$ & $2,097 * *$ & $\begin{array}{c}1,232 \mathrm{a} \\
3,570\end{array}$ & 0,163 \\
\hline Modelo 2 & İ & $1.212 *$ & 0,194 & $\begin{array}{l}\text { Aderência à } \\
\text { mudançaX Sistema } \\
\text { de Comunicação e } \\
\text { Percepção sobre } \\
\text { Aspectos Formais }\end{array}$ & $1,044 * *$ & $\begin{array}{c}1,007 \mathrm{a} \\
1,081\end{array}$ & 0,085 \\
\hline Modelo 3 & I & \multicolumn{6}{|c|}{ Não houve significância } \\
\hline Modelo 4 & I & \multicolumn{6}{|c|}{ Não houve significância } \\
\hline Modelo 5 & I & \multicolumn{6}{|c|}{ Não houve significância } \\
\hline Modelo 6 & İ & $\begin{array}{c}4,099 * \\
*\end{array}$ & 0,721 & $\begin{array}{l}\text { Sistema de decisões } \\
\text { e suporte } \\
\text { organizacional }\end{array}$ & $1,589 * *$ & $\begin{array}{c}1,188 \mathrm{a} \\
2,125\end{array}$ & 0,103 \\
\hline
\end{tabular}




\begin{tabular}{|c|c|c|c|c|c|c|c|}
\hline \multirow[t]{3}{*}{$\begin{array}{l}\text { Modelo } \\
\text { da } \\
\text { equação }\end{array}$} & $\begin{array}{l}\text { Etapas } \\
\text { do } \\
\text { modelo }\end{array}$ & $\Delta-2 \mathrm{LL}$ & $\begin{array}{c}\text { Hosmer- } \\
\text { Lemeshow }\end{array}$ & $\begin{array}{l}\text { Variáveis no } \\
\text { modelo }\end{array}$ & $\operatorname{Exp}(B)$ & I.C $(95 \%)$ & $\begin{array}{c}\mathbf{R}^{2} \text { de } \\
\text { Nagelkerke }\end{array}$ \\
\hline & \multirow{2}{*}{ II } & \multirow{2}{*}{$\begin{array}{c}17,175 \\
* *\end{array}$} & \multirow{2}{*}{0,85} & $\begin{array}{l}\text { Participou na } \\
\text { mudança }\end{array}$ & $3,48 * *$ & $\begin{array}{c}1,387 \mathrm{a} \\
8,733\end{array}$ & \multirow{2}{*}{0,173} \\
\hline & & & & $\begin{array}{l}\text { Sistema de decisões } \\
\text { e suporte } \\
\text { organizacional }\end{array}$ & $1,556 * *$ & $\begin{array}{c}1,158 \mathrm{a} \\
2,091\end{array}$ & \\
\hline \multirow{3}{*}{$\begin{array}{l}\text { Modelo } 7 \\
\text { Modelo } 8\end{array}$} & I & \multicolumn{6}{|c|}{ Não houve significância } \\
\hline & I & \multicolumn{6}{|c|}{ Não houve significância } \\
\hline & I & $\begin{array}{c}10,047 \\
* *\end{array}$ & 0,955 & $\begin{array}{l}\text { Aderência à } \\
\text { mudança }\end{array}$ & $1,790 * *$ & $\begin{array}{c}1,236 \mathrm{a} \\
2,592 \\
\end{array}$ & 0,128 \\
\hline \multirow[t]{2}{*}{ Modelo 9} & \multirow{2}{*}{ II } & \multirow{2}{*}{$\begin{array}{c}13,878 \\
* *\end{array}$} & \multirow{2}{*}{0,812} & $\begin{array}{l}\text { Aderência à } \\
\text { mudança }\end{array}$ & $1,531^{*}$ & $\begin{array}{c}1,032 \mathrm{a} \\
2,269 \\
\end{array}$ & \multirow{2}{*}{0,175} \\
\hline & & & & $\begin{array}{l}\text { EscolaridadeXAder } \\
\text { ência à mudança }\end{array}$ & 1,055 & $\begin{array}{c}0,999 \mathrm{a} \\
1,115\end{array}$ & \\
\hline \multirow[t]{2}{*}{$\begin{array}{l}\text { Modelo } \\
10\end{array}$} & I & $\begin{array}{c}8,598 * \\
*\end{array}$ & 0,756 & $\begin{array}{l}\text { Sistema de } \\
\text { Comunicação e } \\
\text { Percepção sobre } \\
\text { Aspectos Formais }\end{array}$ & $2,144 * *$ & $\begin{array}{c}1,282 \mathrm{a} \\
3,586\end{array}$ & 0,17 \\
\hline & I & $\begin{array}{c}11,825 \\
* *\end{array}$ & 0,019 & $\begin{array}{l}\text { Aderência à } \\
\text { mudança X } \\
\text { Percepção sobre a } \\
\text { chefia e a equipe }\end{array}$ & $0,957 * *$ &, 430 a ,810 & 0,125 \\
\hline \multirow[t]{2}{*}{$\begin{array}{c}\text { Modelo } \\
11\end{array}$} & \multirow[b]{2}{*}{ II } & \multirow{2}{*}{$\begin{array}{c}17,587 \\
* *\end{array}$} & \multirow[b]{2}{*}{0,319} & $\begin{array}{l}\text { Gênero X } \\
\text { Aderência à } \\
\text { mudança }\end{array}$ & $0,845^{*}$ & $\begin{array}{c}0,728 \mathrm{a} \\
0,980\end{array}$ & \multirow[b]{2}{*}{0,182} \\
\hline & & & & $\begin{array}{l}\text { Aderência à } \\
\text { mudança X } \\
\text { Percepção sobre a } \\
\text { chefia e a equipe }\end{array}$ & $0,960 * *$ & $\begin{array}{c}0,936 \mathrm{a} \\
0,985\end{array}$ & \\
\hline \multirow[t]{6}{*}{$\begin{array}{c}\text { Modelo } \\
12\end{array}$} & I & $\begin{array}{c}7,447 * \\
*\end{array}$ & 0,165 & $\begin{array}{l}\text { Gênero X } \\
\text { Aderência à } \\
\text { mudança }\end{array}$ & $0,899 * *$ & $\begin{array}{c}0,833 \mathrm{a} \\
0,972\end{array}$ & 0,057 \\
\hline & \multirow[b]{2}{*}{ II } & \multirow{2}{*}{$\begin{array}{l}14,075 \\
* *\end{array}$} & \multirow[b]{2}{*}{0,810} & $\begin{array}{l}\text { Participou da } \\
\text { mudança }\end{array}$ & $2,452 * *$ & $\begin{array}{c}1,219 \mathrm{a} \\
4,933\end{array}$ & \multirow[b]{2}{*}{0,106} \\
\hline & & & & $\begin{array}{l}\text { Gênero X } \\
\text { Aderência à } \\
\text { mudança }\end{array}$ & $0,886 * *$ & $\begin{array}{c}0,819 \mathrm{a} \\
0,960\end{array}$ & \\
\hline & \multirow{3}{*}{ III } & \multirow{3}{*}{$\begin{array}{c}18,245 \\
* * *\end{array}$} & \multirow{3}{*}{0,118} & $\begin{array}{l}\text { Participou da } \\
\text { mudança }\end{array}$ & $2,313^{*}$ & $\begin{array}{c}1,140 \mathrm{a} \\
4,693 \\
\end{array}$ & \multirow{3}{*}{0,135} \\
\hline & & & & $\begin{array}{l}\text { Vínculo funcional } \\
X \text { aderência à } \\
\text { mudança }\end{array}$ & $0,986^{*}$ & 0,973 a 1 & \\
\hline & & & & $\begin{array}{l}\text { GêneroXaderência à } \\
\text { mudança }\end{array}$ &, $878 * *$ & $\begin{array}{c}0,809 \mathrm{a} \\
0,952\end{array}$ & \\
\hline
\end{tabular}




\begin{tabular}{|c|c|c|c|c|c|c|}
\hline $\begin{array}{l}\text { Modelo } \\
\text { da } \\
\text { equação }\end{array}$ & $\begin{array}{c}\text { Etapas } \\
\text { do } \\
\text { modelo }\end{array}$ & $\Delta-2 \mathrm{LL}$ & $\begin{array}{c}\text { Hosmer- } \\
\text { Lemeshow }\end{array}$ & $\begin{array}{l}\text { Variáveis no } \\
\text { modelo }\end{array}$ & I.C (95\%) & $\begin{array}{c}\mathbf{R}^{2} \text { de } \\
\text { Nagelkerke }\end{array}$ \\
\hline $\begin{array}{c}\text { Modelo } \\
13\end{array}$ & I & & & Não houve significância. & & \\
\hline
\end{tabular}

Do 13 modelos testados, foram percebidos indícios de relações de moderação em cinco deles, porém com resultados variados. A variável "componentes da estrutura organizacional" aparece como moderadora em 2 modelos. De forma geral, a inserção da moderação tendeu a reduzir o poder preditivo da variável "aderência à mudança" na percepção de um determinado resultado organizacional. Isso pode indicar que as duas variáveis compartilham variância nos modelos reduzidos apresentados.

Variáveis pessoais e profissionais também apresentaram relação de moderação. No caso do modelo 9, a variável "escolaridade" apareceu como moderadora de " aderência à mudança"; porém, como o $\operatorname{Exp}(B)$ está muito próximo de 1, isso pode significar um efeito bastante fraco, ainda que estatisticamente significante.

A variável "aderência à mudança" aparece como moderadora no Modelo 12, com o efeito de alterar o coeficiente da variável "gênero" próximo de 1. No caso da regressão logística, um coeficiente próximo de 1 indica que não há alteração na razão de chance em função da variável cujo efeito moderador foi testado, ou seja, no caso do Modelo 12, a chance de se perceber um afastamento entre as áreas do Cade diminuiu com a entrada da variável "aderência à mudança" para a variável gênero, indicando uma possível inversão na direção da relação entre a variável preditora e a critério.

Esse achado não estava abarcado na hipótese 2 desse estudo, e pode indicar algum tipo de enquadramento positivo frente a resultados de conotação negativa. Esse mesmo efeito pode ser inferido da análise da moderação do fator "percepção sobre a chefia e a equipe" sobre a variável "aderência à mudança" no Modelo 11, uma vez que houve uma aproximação da razão de chance a 1. Essa diminuição pode ser interpretada da seguinte maneira: quanto mais positiva a percepção sobre a chefia e sobre a interação da equipe, menor é a chance de haver percepção de uma diminuição na cooperação entre as equipes no Cade. Essa relação de moderação apresenta 
coerência com o conteúdo do fator, especialmente considerando-se que um dos itens versa justamente sobre a relação entre integração das pessoas e a eficiência da organização.

Para facilitar a referência entre os diversos resultados narrados, foi construída a Tabela 10, que apresenta as variáveis que apresentaram níveis de significância estatística $(\mathrm{p}<0,005)$ para cada uma das etapas realizadas, com a razão de chance $[\operatorname{Exp}(B)]$ entre parênteses.

Tabela 10

\section{Resumo dos resultados encontrados em termos de significância de variáveis}

\begin{tabular}{|c|c|c|c|}
\hline $\begin{array}{l}\text { Variável } \\
\text { dependente }\end{array}$ & $\begin{array}{l}\text { Etapa } 1 \text { - apenas } \\
\text { aderência à } \\
\text { mudança }\end{array}$ & $\begin{array}{l}\text { Etapa } 2 \text { - inserção de } \\
\text { variáveis pessoais e } \\
\text { profissionais e os } \\
\text { componentes da estrutura }\end{array}$ & Etapa 3 - estudos de moderação \\
\hline Resultado 1 & $\begin{array}{l}\text { Aderência à mudança } \\
(2,12)\end{array}$ & $\begin{array}{l}\text { Aderência à mudança } \\
(2,097)^{3}\end{array}$ & $\begin{array}{l}\text { Não houve significância para o } \\
\text { teste de moderação. }\end{array}$ \\
\hline Resultado 2 & $\begin{array}{l}\text { Aderência à mudança } \\
(1,56)\end{array}$ & $\begin{array}{l}\text { Aderência à mudança } \\
(1,53)^{3}\end{array}$ & $\begin{array}{l}\text { Aderência à mudança X Sistema } \\
\text { de Comunicação e Percepção } \\
\text { sobre Aspectos Formais }(1,044) \\
3\end{array}$ \\
\hline Resultado 3 & $\begin{array}{l}\text { Não houve } \\
\text { significância }\end{array}$ & Não houve significância & $\begin{array}{l}\text { Não houve significância para o } \\
\text { teste de moderação. }\end{array}$ \\
\hline Resultado 4 & $\begin{array}{l}\text { Não houve } \\
\text { significância }\end{array}$ & Não houve significância & $\begin{array}{l}\text { Não houve significância para o } \\
\text { teste de moderação. }\end{array}$ \\
\hline Resultado 5 & $\begin{array}{l}\text { Não houve } \\
\text { significância }\end{array}$ & Não houve significância & $\begin{array}{l}\text { Não houve significância para o } \\
\text { teste de moderação. }\end{array}$ \\
\hline Resultado 6 & $\begin{array}{l}\text { Aderência à mudança } \\
(1,487)\end{array}$ & $\begin{array}{l}\text { Participou da mudança } \\
(3,48)^{2,3} \\
\text { Sistema de decisões e } \\
\text { suporte organizacional } \\
(1,556)\end{array}$ & $\begin{array}{l}\text { Não houve significância para o } \\
\text { teste de moderação. }\end{array}$ \\
\hline Resultado 7 & $\begin{array}{l}\text { Não houve } \\
\text { significância }\end{array}$ & Não houve significância & $\begin{array}{l}\text { Não houve significância para o } \\
\text { teste de moderação. }\end{array}$ \\
\hline Resultado 8 & $\begin{array}{l}\text { Não houve } \\
\text { significância }\end{array}$ & Não houve significância & $\begin{array}{l}\text { Não houve significância para o } \\
\text { teste de moderação. }\end{array}$ \\
\hline
\end{tabular}




\begin{tabular}{|c|c|c|c|}
\hline $\begin{array}{l}\text { Variável } \\
\text { dependente }\end{array}$ & $\begin{array}{l}\text { Etapa } 1 \text { - apenas } \\
\text { aderência à } \\
\text { mudança }\end{array}$ & $\begin{array}{l}\text { Etapa } 2 \text { - inserção de } \\
\text { variáveis pessoais e } \\
\text { profissionais e os } \\
\text { componentes da estrutura }\end{array}$ & Etapa 3 - estudos de moderação \\
\hline Resultado 9 & $\begin{array}{l}\text { Aderência à mudança } \\
(1,811)\end{array}$ & $\begin{array}{l}\text { Aderência à Mudança } \\
(1,79) 3,4\end{array}$ & $\begin{array}{l}\text { Não houve significância para o } \\
\text { teste de moderação. }\end{array}$ \\
\hline Resultado 10 & $\begin{array}{l}\text { Não houve } \\
\text { significância }\end{array}$ & $\begin{array}{l}\text { Sistema de Comunicação e } \\
\text { Percepção sobre Aspectos } \\
\text { Formais }(2,144)\end{array}$ & $\begin{array}{l}\text { Aderência à mudança X } \\
\text { Percepção sobre a chefia e a } \\
\text { equipe }(0,957)^{4}\end{array}$ \\
\hline Resultado 11 & $\begin{array}{l}\text { Aderência à mudança } \\
(0,627)\end{array}$ & $\begin{array}{l}\text { Aderência à mudança } \\
(0,591)^{2,3}\end{array}$ & $\begin{array}{l}\text { Gênero X Aderência à mudança } \\
(0,845) \\
\text { Aderência à mudança X } \\
\text { Percepção sobre a chefia e a } \\
\text { equipe }(0,960)^{2}\end{array}$ \\
\hline Resultado 12 & $\begin{array}{l}\text { Não houve } \\
\text { significância }\end{array}$ & $\begin{array}{l}\text { Gênero }(3,24) \\
\text { Tempo de serviço (10 anos } \\
\text { ou mais) }(7,51) \\
\text { Vínculo funcional } \\
\text { Participou da mudança } \\
(0.269)\end{array}$ & $\begin{array}{l}\text { Vínculo funcional X Aderência à } \\
\text { mudança }(0,986) \\
\text { Gênero X Aderência à mudança } \\
(0,878)\end{array}$ \\
\hline $\begin{array}{l}\text { Modelo } \\
\text { empírico da } \\
\text { pesquisa }\end{array}$ & $\begin{array}{l}\text { Aderência à mudança } \\
(1,267)\end{array}$ & $\begin{array}{l}\text { Ocupa cargo de chefia } \\
(4,495)^{2} \\
\text { Participou da mudança } \\
(3,658)^{2}\end{array}$ & Não houve significância \\
\hline
\end{tabular}

Nota: ${ }^{1}$ Houve aumento no coeficiente da variável $[\operatorname{Exp}(\mathrm{B})] ;{ }^{2}$ Houve aumento da variância explicada $\left(\mathrm{R}^{2}\right.$ de Nagelkerke); ${ }^{3}$ Houve diminuição no coeficiente da variável $[\operatorname{Exp}(\mathrm{B})] ;{ }^{4}$ Houve diminuição da variância explicada $\left(\mathrm{R}^{2}\right.$ de Nagelkerke).

Fonte: Elaborada pela autora

\subsubsection{Resultado dos testes não paramétricos}

A terceira hipótese dessa dissertação diz respeito a possível diferença estatisticamente significativa na formação da aderência à mudança entre os grupos das áreas fim e meio. Para tal, 
foram testadas as diferenças em relação às variáveis lotação, codificada como área meio (0) e área fim (1); participação da mudança, codificada como não participante (0) e participante (1); ex-servidor, codificado como ex-servidor (0) e servidor atual (1); ocupa chefia, codificada como não (0) e sim (1).

Foi utilizado o teste de Mann-Whitney, uma vez que se deseja comparar duas amostras independentes para cada exemplo, com o método de cálculo exato. Nesse teste, a hipótese nula é a de que não há diferença entre grupos na formação da variável analisada; dessa forma, se for obtido um valor não significativo ( $\mathrm{p}>0,05)$, deve-se reter a hipótese nula. $\mathrm{O}$ resultado agregado está disponível na Tabela 12.

Tabela 11.

Resultado dos testes de Mann-Whitney para a variável "aderência à mudança"

\begin{tabular}{|c|c|c|c|c|}
\hline & \multicolumn{4}{|c|}{ Variável Agrupadora } \\
\hline & Área meio ou fim & $\begin{array}{l}\text { Participou da } \\
\text { mudança }\end{array}$ & Ex-servidor & Ocupa chefia \\
\hline Estatística U & 3911 & 2786,5 & 1134 & 1848 \\
\hline $\begin{array}{l}\text { Significancia assintótica } \\
\text { (bilateral) }\end{array}$ & 0,988 & 0,047 & 0,150 & 0,000 \\
\hline $\begin{array}{l}\text { Significância exata } \\
\text { (bilateral) }\end{array}$ & 0,989 & 0,047 & 0,152 & 0,000 \\
\hline $\begin{array}{l}\text { Significância exata } \\
\text { (unilateral) }\end{array}$ & 0,494 & 0,023 & 0,076 & 0,000 \\
\hline Resultado do teste & $\begin{array}{c}\text { Não há diferença } \\
\text { na formação da } \\
\text { variável } \\
\text { aderência à } \\
\text { mudança }\end{array}$ & $\begin{array}{l}\text { Há diferença na } \\
\text { formação da } \\
\text { variável aderência } \\
\text { à mudança }\end{array}$ & $\begin{array}{c}\text { Não há } \\
\text { diferença na } \\
\text { formação da } \\
\text { variável } \\
\text { aderência }\end{array}$ & $\begin{array}{c}\text { Há diferença } \\
\text { na formação } \\
\text { da variável } \\
\text { aderência à } \\
\text { mudança }\end{array}$ \\
\hline
\end{tabular}

Fonte: Elaborada pela autora

Com base nos resultados apresentados na Tabela 11, foi utilizado o diagrama de caixa e bigodes (box plot) para criar uma visualização gráfica da diferença da formação da variável 
"aderência à mudança", apresentadas nas Figuras 7 e 8. As estatísticas descritivas para cada grupo foram compiladas na Tabela 12.

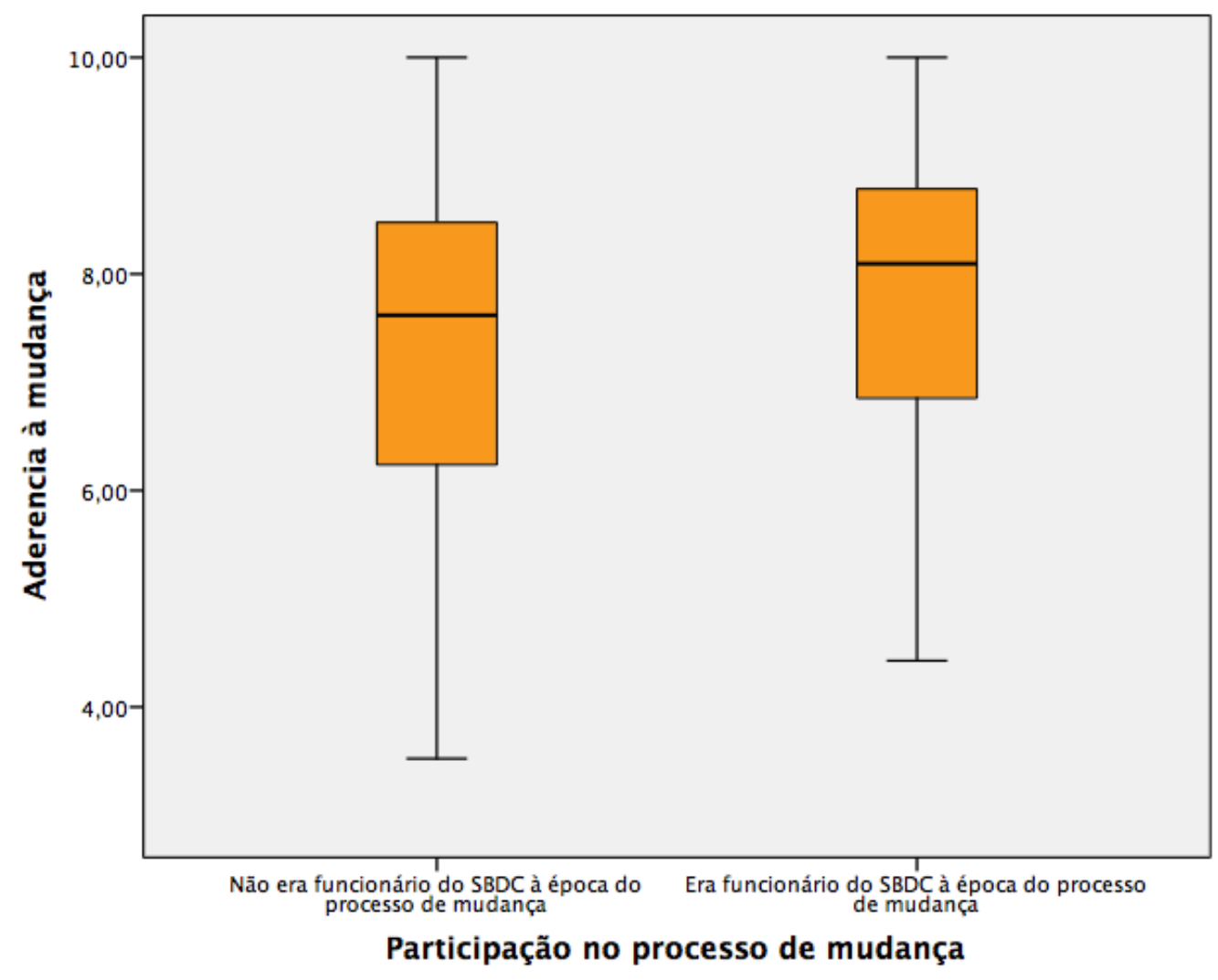

Figura 7. Diferença na formação da variável "aderência à mudança" em função da participação no processo de mudança organizacional

Fonte: elaborada pela autora 


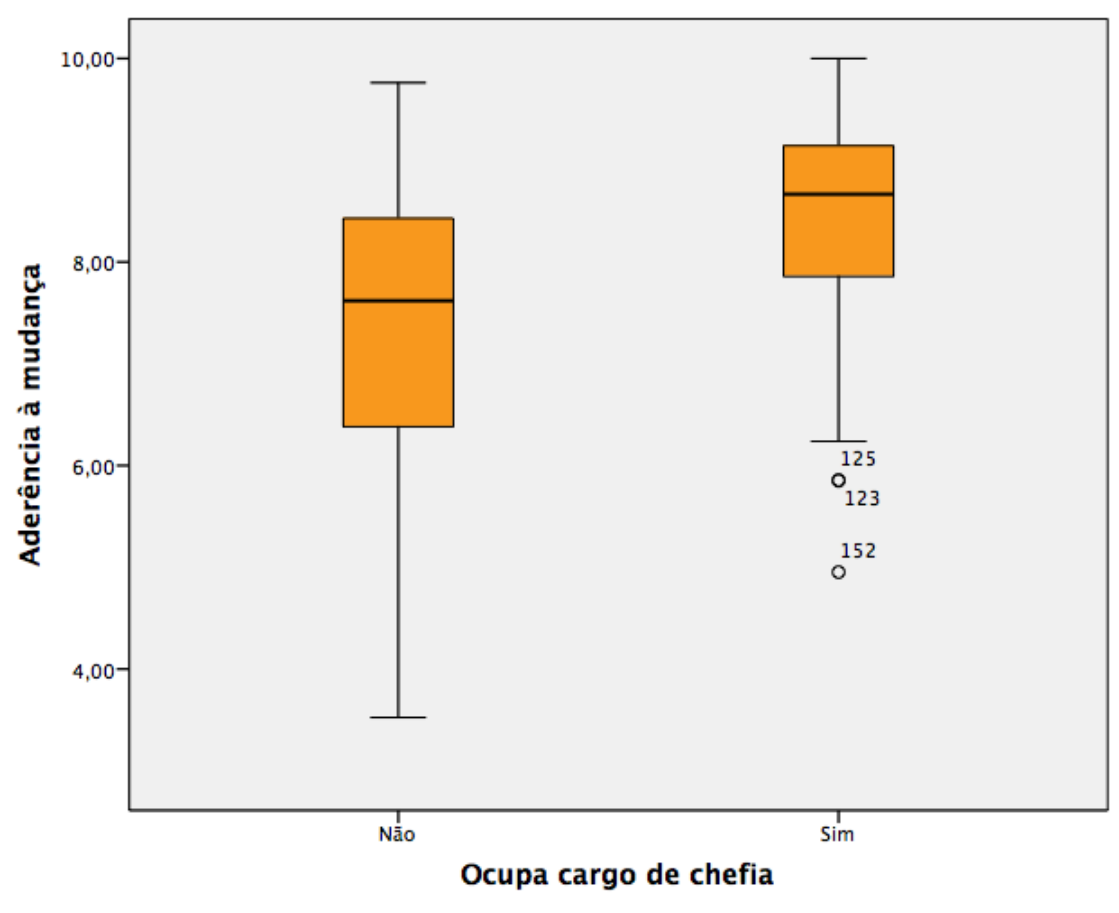

Figura 8. Diferença na formação da variável "aderência à mudança" por ocupantes em cargos de chefia

Fonte: elaborada pela autora

Tabela 12

Estatísticas descritivas da formação da aderência à mudança segmentada por grupos

\begin{tabular}{l|l|c|c|c|c|c|}
\hline \multicolumn{2}{l|}{ Variável agrupadora } & Frequência & Média & Desvio Padrão & Mínimo & Máximo \\
\multirow{2}{*}{ Ocupa chefia } & Sim & 58 & 8,35 & 1,17 & 4,95 & 10 \\
\cline { 2 - 8 } & Não & 144 & 7,31 & 1,41 & 3,52 & 9,76 \\
\hline $\begin{array}{l}\text { Era parte do } \\
\text { SBDC à época da } \\
\text { mudança }\end{array}$ & Sim & 120 & 7,8 & 1,31 & 4,43 & 10 \\
\cline { 2 - 8 } & Não & 57 & 7,3 & 1,57 & 3,52 & 10 \\
\hline
\end{tabular}

Fonte: Elaborada pela autora 
As estatísticas descritivas por grupo indicam que a média da variável aderência à mudança para aqueles que estavam no Cade à época do processo de mudança é de 7,8, contra 7,3 daqueles que não estavam no processo; pelo resultado dos testes não paramétricos, essa diferença é estatisticamente significativa. O desvio padrão para o primeiro grupo também é menor, o que indica um grau levemente maior de homogeneidade das respostas. Esse resultado pode indicar que as estratégias de engajamento e convencimento dos funcionários do Cade possa ter influenciado na formação da aderência à mudança, ou seja, há variáveis relativas à condução do processo de mudança organizacional que podem explicar essa diferença.

No caso do agrupamento por ocupantes de cargo de chefia, a diferença na formação da variável é mais pronunciada, com uma média de 8,35 para ocupantes de cargo de chefia contra 7,31 de não ocupantes. Esse padrão se repete na medida de dispersão para cada grupo (desviopadrão de 1,14 para ocupantes de cargo de chefia, em comparação a 1,41 dos não ocupantes). Essa constatação é coerente com o perfil dos outliers mapeados, uma vez que eles obtiveram escores menores nos itens da variável "aderência à mudança" e a maior parte deles não ocupa cargo de chefia. Esse resultado pode ser explicado pelo fato de que, nas entrevistas, foi mencionado que as chefias ocupavam posições-chave nas discussões estratégicas e táticas sobre o processo de mudança organizacional e, por conseguinte, havia mais oportunidades de criação de uma visão compartilhada com esses indivíduos.

\subsection{Resultados do Estudo 3}

Os resultados do grupo focal foram analisados por meio da análise de conteúdo (Bardin, 2011), com base nas categorias obtidas previamente, e que guiaram as perguntas do grupo focal e da entrevista. Adicionalmente, buscou-se investigar a percepção sobre o tempo em que a mudança o ocorreu, sobre grau de sucesso da mudança, se houve reações variadas ao processo e se há alguma relação entre a formação das reações observadas e o sucesso (ou não) do processo relatado. Com base nas respostas, novas categorias foram inseridas.

As informações obtidas permitiram traçar um contraponto entre a percepção dos envolvidos na concepção de toda a mudança organizacional e os recipientes desse processo. Os resultados obtidos buscam interpretar a experiência da organização em tela e, dessa forma, não podem ser generalizados. 


\subsubsection{Mudanças percebidas e esperadas pelos participantes}

A primeira mudança relatada pelos participantes do grupo focal foi a melhora da estrutura física do Cade, o que teve impacto bastante positivo na percepção dos participantes. A segunda grande mudança relatada foi o aumento do distanciamento entre as pessoas. Como causas, o grupo apontou o grande crescimento da estrutura organizacional, a chegada de muitas pessoas novas à organização e a nova configuração das equipes. Segundo os participantes, antes as pessoas "esbarravam mais, interagiam mais", e agora há menos oportunidades para isso. A mudança de pessoas entre os setores teve como conseqüência a perda de parte do seu histórico de atuação.

Um segundo bloco de mudanças percebidas pelos participantes foi o de prazos de análises de processos. Quando o grupo foi instado a detalhar mais essas mudanças, foi ressaltado que as pessoas que não lidam muito com a área fim do Cade não percebe com mais detalhes essas alterações, mas que era possível perceber que o trabalho estava, de forma geral, mais rápido. A servidora representante da área fim relatou que houve mudança na forma de triagem e priorização dos casos, mas que, além da mudança do processo de análise de Atos de Concentração, as outras rotinas mantiveram-se estáveis. $\mathrm{Na}$ área meio, foi relatada como principal mudança a estrutura organizacional, com a criação de mais Coordenações-Gerais, acarretando no aumento do fluxo de trabalho e da qualidade, mas também mais autonomia para a Diretoria Administrativa como um todo. Essa mudança na área meio foi percebida como bastante positiva, inclusive com um relato na melhora no acesso a serviço e materiais necessários ao trabalho. Quando perguntados sobre as mudanças nos fluxos de trabalho, foi relatado que não havia muita clareza sobre adequação de rotinas e novos fluxos de trabalho, apenas sabia-se que o volume de trabalho iria aumentar.

Com relação aos resultados esperados do processo de mudança, os participantes do grupo focal relataram que havia uma sensação geral de que a atuação do Cade iria melhorar, com maior notoriedade para o órgão, e mais importância dentro do governo federal. Alem desse sentimento, os participantes disseram que não era possível saber exatamente o que esperar. Ainda assim, o grupo identificou que havia uma expectativa, por parte de um conjunto de pessoas, de promoção, em virtude do aumento na estrutura organizacional; porém, essa expectativa foi frustrada, pois várias pessoas de fora acabaram ocupando esses cargos. 
O representante da SDE relatou como primeiro resultado o fato do Cade poder atuar de maneira mais estratégica na construção e execução da política pública de defesa da concorrência, pois a fragmentação entre órgãos levava a um desvinculamento entre as partes e o resultado final esperado. A fusão permitiu uma visão completa do processo de instrução e julgamento de um caso e criou oportunidade para melhorar a atuação do Conselho como um todo. O entrevistado também relatou a possibilidade de atuação mais estratégica da área administrativa, canalizando forças para o trabalho do sistema. Essa nova atuação também exigiu em uma mudança de filosofia dentro da própria Diretoria Administrativa.

Essas alterações repercutiram sobre o clima organizacional: na visão do entrevistado, as pessoas sentem-se mais conectadas ao papel e à missão institucional do órgão do que apenas ao Cade, o que aumentou o comprometimento. Alem disso, hoje é possível falar de uma cultura organizacional integrada, e a entrada de novas pessoas contribuiu para eliminar conflitos existentes anteriormente.

Sobre os resultados esperados, o entrevistado relatou que, como ele trabalhou muito próximo do processo, as mudanças esperadas eram claras para ele, e que os servidores da SDE podiam não compartilhar dessa visão. De forma geral, esperava-se que o Cade ganhasse a estrutura física e normativa de que carecia, e essa expectativa realizou-se em parte. No meio externo, havia muita preocupação com a capacidade da Autarquia em conseguir absorver as novas atribuições, mas essa expectativa desfez-se nos primeiros seis meses. No que concerne os processos de trabalho, não era possível prever o que iria acontecer pelo grau de mudanças ocorrido. A mudança também propiciou um momento de renovação de equipe, com algumas pessoas saindo da SDE motivadas pelo momento de mudança, e outras que optaram por ficar.

\subsubsection{Percepção de planejamento da mudança}

O grupo associou a experiência com a mudança de sede com o questionamento sobre a existência de um planejamento prévio. A percepção compartilhada é a de que houve um planejamento da mudança física "que não saiu do papel”, de que o processo foi tumultuado e realizado em um tempo muito curto. Havia uma expectativa de que a mudança se realizaria com quase toda a nova sede pronta, mas isso não se realizou. Esse fato teve impacto negativo sobre a formação das novas equipes e o ritmo de trabalho ficou prejudicado por um tempo, embora tenha sido restabelecido. 
O entrevistado relatou que, em sua percepção, houve um planejamento do processo em várias etapas, com muitas modificações ao longo do tempo. Havia uma preocupação dos dirigentes com a possibilidade do cenário político alterar-se para a aprovação da lei, mas a preocupação real com o planejamento veio no final do ano de 2010, com a passagem do Projeto de Lei do Senado para a Câmara dos deputados. O tempo percebido para realizar todas as mudanças necessárias era curto; dessa forma, o Secretário de Direito Econômico estabeleceu com o Conselho as principais diretrizes do processo, inclusive com a formação dos grupos de transição principais para o processo (proposta de organograma, alterações nas normas infralegais e análise de pontos de veto para a Lei no. 12.529/2011, especificação e montagem de nova sede). $\mathrm{O}$ entrevistado ainda relatou que o processo de planejamento foi bastante aberto, pois as autoridades não traziam idéias pré-concebidas e delegaram esse pensamento para um grupo maior de pessoas, o que permitiu o amadurecimento das soluções a serem propostas.

\subsubsection{Fatores que facilitaram e dificultaram o processo}

Como fatores facilitadores, o grupo apontou que o processo de comunicação das etapas foi importante, especialmente para a equipe que vinha da SDE e precisava adotar providencias administrativas (como a finalização de contratos). Ainda assim, seus resultados foram limitados, pois a ênfase era grande nas mudanças trazidas pela Lei, e não contribuiu para prever as mudanças da prática, do dia-a-dia, especialmente na área meio (o Tribunal Administrativo sentiu menos esse período conturbado). Ainda segundo o grupo, para a área meio, o período de mudança mesmo ocorreu no segundo semestre de 2012, o que denota uma percepção diferente de quando ocorreu o processo de mudança organizacional. Outro aspecto facilitador apontado foi o fato da nova sede já estar escolhida, com uma infraestrutura muito melhor do que a anterior.

Para o entrevistado, foram aspectos facilitadores a harmonia entre as lideranças do Cade, o que facilitou o planejamento e a execução do processo. Outro fator facilitador foi a cultura de comprometimento dos funcionários com o trabalho realizado pelo Cade, o que contribuiu para superar as desconfianças que surgiram e resolver os conflitos. Esse comprometimento contribuiu também para a adaptação a novas equipes e chefias, bem como amenizou o não cumprimento de expectativas relativas a promoções. 
Como fatores dificultadores do processo, o grupo relatou que o principal foi a falta de recursos humanos, e que esse fator permanece. O tempo curto, em conjunção com a falta de equipe, prejudicou um pouco o andamento do processo de mudança.

Para o entrevistado, o principal fator dificultador foi a limitação orçamentária do projeto, que só vieram quase que ao final do processo. Ele ressaltou que a mudança como um todo só funcionou porque havia uma crença de que as coisas dariam certo, parte em virtude de estratégias já traçadas para contornar os problemas encontrados. $\mathrm{O}$ ambiente de incerteza relativo a mudança foi um segundo fator, inclusive indefinição das equipes, mas seu impacto foi menor em virtude do comprometimento da equipe. Por fim, um terceiro dificultador foi a ausência de um sistema de gerenciamento de processos que fosse eficaz, e que garantisse que nenhuma informação seria perdida no processo de mudança organizacional.

\subsubsection{Reações verificadas}

O grupo relatou que as manifestações das pessoas foram bastante positivas, com boas expectativas. A mudança era percebida como algo positivo, algo esperado. O grupo relatou também comportamentos de engajamento e cooperação, especialmente na mudança física de sede, em que as pessoas realizaram tarefas que não fariam normalmente, justamente para ajudar aos outros. Os participantes do grupo relataram, ainda, que as pessoas do Cade se sentiram parte do processo, e que esse engajamento ajudou a reduzir o tempo necessário para a mudança de sede ocorrer. Foi ressaltado o engajamento das chefias no processo também. Por fim, o grupo relatou que houve algumas pessoas com um menor grau de engajamento, que foram "na onda do processo, esperando ver o que ia acontecer".

O entrevistado relatou que, na SDE, a primeira sensação era de incredulidade de que a mudança organizacional efetivamente se realizaria; ainda assim, havia apoio ao projeto, ligado à percepção de que era uma mudança necessária e que traria benefícios, apesar das incertezas, e que não foram relatadas quaisquer insatisfações com o processo de forma geral. Ainda assim, o entrevistado relatou ter percebido um menor grau de participação da equipe da Cade nos grupos que estavam discutindo a mudança. A participação dos servidores da SDE foi maior para aqueles que possuíam cargo de chefia, ou que assessoravam diretamente o Secretário. 


\subsubsection{Percepção dos componentes da estrutura organizacional.}

Foi possível identificar componentes semelhantes nas falas dos participantes do grupo focal e do entrevistado. Em um primeiro momento, a identificação de itens da estrutura relacionou-se com a estrutura física (no caso, a sede), a estrutura organizacional formal e o sistema hierárquico. Outros componentes foram citados, por exemplo, o sistema de atribuição de responsabilidade e autonomia (representados nas narrativas sobre a alteração da estrutura e dos fluxos de trabalho) e os aspectos informais. Percebe-se da fala dos participantes que esses itens sofreram alterações durante o processo de mudança organizacional, enquadrando-se, em alguns momentos, no rol de mudanças percebidas.

Dois fatores apareceram na fala dos participantes como importantes para a consecução dos resultados: o sistema de comunicação (tanto no planejamento da mudança quanto na comunicação efetiva das providências tomadas e do prazo estimado) e a influência de lideranças informais, formada por servidores sem cargo de chefia e por chefias mais envolvidas na execução do que no processo decisório, separadas das autoridades encarregadas de liderar o processo. Depreende-se que a relação dos componentes da estrutura organizacional é mais complexa do que uma relação de moderação, podendo configurar-se em variável explicativa de alguns resultados mapeados, conforme encontrado no Estudo 2.

O próximo Capítulo apresentará a discussão dos resultados obtidos nos três estudos conduzidos 


\section{Discussão dos resultados}

Neste Capítulo, serão discutidos os resultados no Capítulo 5 da presente dissertação. A discussão foi organizada da seguinte forma: primeiro, será comentada a formação da variável "aderência à mudança", conforme resultados do Estudo 1. Após, serão apresentadas algumas considerações sobre os resultados dos Estudos 1, 2 e 3 com base em cada uma das hipóteses desse estudo.

Considera-se que os objetivos geral e específicos foram atingidos por meio da realização dos três estudos apresentados neste trabalho. O objetivo geral definido para esse trabalho era identificar, empiricamente, a influência da aderência à mudança sobre os resultados percebidos, considerando-se o papel moderador de componentes da estrutura organizacional, no Conselho Administrativo de Defesa Econômica.

Como objetivos específicos, tinham-se:

- Construir e verificar evidências de validade de um instrumento de pesquisa sobre aderência à mudança;

- Testar empiricamente a relação entre a aderência à mudança e resultado percebido da mudança organizacional.; e

- Verificar empiricamente a influência dos componentes da estrutura organizacional na relação entre as variáveis aderência à mudança e resultado percebido.

O primeiro objetivo específico, construção e validação de um instrumento de pesquisa sobre aderência à mudança, foi atingido. A escala foi elaborada com base na literatura e nas entrevistas realizadas no âmbito do Estudo 1. Os requisitos para validação - numero mínimo de observações por item e fatorabilidade - foram atingidos, conforme apresentado no Capítulo 5, com uma razão de observações por item de 8 para 1, e KMO de 0,871. Essa solução explicou $43 \%$ da variância. A escala obteve alto grau de coerência interna, com alpha de Cronbach de 0,916. Salienta-se que a melhor solução encontrada para essa dissertação foi a unifatorial, ainda que, inicialmente, havia-se pretendido elaborar uma escala tridimensional. É importante ressaltar, porém, que há consistência teórica para uma solução unifatorial, considerando a conexão relevante entre cognições, afetos e intenções de comportamento (Rodrigues et al, 2009). Além 
disso, houve itens com baixas comunalidades, o que pode indicar a proposição de uma versão reduzida da escala inicial, verificando se esses itens tratariam, na verdade, de um segundo constructo versando sobre fatores de suporte à mudança organizacional.

O objetivo geral definido para esse trabalho era identificar, empiricamente, a influência da aderência à mudança sobre os resultados percebidos, considerando-se o papel moderador de componentes da estrutura organizacional, que foram objetos das hipóteses 1 e 2 . Antes de iniciar a discussão sobre os resultados das hipóteses de estudo, foi necessário verificar o comportamento da variável "aderência à mudança". Conforme relatado, os itens que compuseram o fator de aderência à mudança apresentaram forte assimetria positiva. A análise descritiva do fator de aderência à mudança indica uma média de 7,70 (D.P.=1,42, N=177) em uma escala que variou de 1 a 10), com um ponto de mínimo de 3,52. As medidas de assimetria $(-0,618)$ e curtose $(-0,233)$ indicam uma distribuição platocúrtica, com concentração dos dados na parte direita da curva normal. O Estudo 2 também oferece evidências de que a reação dos funcionários do Cade frente ao processo de mudança organizacional foram orientadas por atitudes de aderência à mudança. Dessa forma, os achados sobre a variável aderência à mudança suportam a hipótese de que atitudes positivas influenciam nos resultados dos processos de mudança organizacional - por xemplo, conforme proposto Weiner (2009), e identificado por Oreg et al (2011).

Embora não tenha sido um dos objetivos desse estudo, percebeu-se, por meio dos resultados obtidos no grupo focal, que fatores como a cultura organizacional de comprometimento, comunicação e compartilhamento de visão (por meio do teste não paramétrico de diferença entre grupos pela variável “ocupa cargo de chefia”) podem ter contribuído para o reforço dessa atitude pró-mudança (Balogun, 2007; Kotter, 1995) e, em última instância, contribuir para o sucesso de uma intervenção organizacional (Avey, Werssing \& Luthans, 2008). Essa conclusão é consistente com a encontrada por Oreg e Berson (2011) em um estudo sobre a influência das lideranças (seu papel, suas predisposições e suas características de personalidade) sobre a formação de atitudes dos subordinados. Dessa forma, a inserção de variáveis como o comprometimento podem aumentar o poder explicativo do modelo.

No Estudo 3, foi possível observar, por meio do relato dos participantes, a ocorrência de atitudes mais variadas frente à mudança, em especial a ambigüidade na avaliação dos possíveis impactos e o ceticismo de que a mudança se concretizaria (em virtude da longa história de 
tramitação do projeto de lei no Congresso Nacional), conforme postulado por Piderit (2000). Esse achado apresenta evidências que podem corroborar as proposições teóricas de que há variedade na formação de atitudes frente à mudança (Lines, 2005; Piderit, 2000), e de que a resistência não é necessariamente a primeira reação a um processo de mudança organizacional (Hernandez \& Caldas, 2001). Esses achados vão ao encontro dos relatados por Neiva (2004), que verificou a ocorrência de atitudes de aceitação e ceticismo em um estudo longitudinal. Importa salientar que não foi possível verificar se houve mudança de atitudes ao longo do processo de mudança em virtude do recorte da pesquisa; porém, o teste de diferença entre grupos controlado pela variável "participou da mudança" indicou que aqueles que eram funcionários do SBDC à época possuem um escore médio mais alto de aderência à mudança do que aqueles que não participaram. Dessa forma, há indícios de que intervenções realizadas durante o processo de mudança organizacional do Cade contribuíram para a formação da aderência à mudança.

Por meio da realização das regressões logísticas, foi possível observar que a aderência à mudança apresentou-se como estatisticamente significante em alguns dos modelos empíricos reduzidos. No modelo empírico da dissertação, a variável apresentou significância estatística quando inserida isoladamente, relacionando-se positivamente com a variável critério. Quando as variáveis pessoais e profissionais e os fatores da variável "componentes da estrutura organizacional" foram inseridas no modelo, as relações empíricas observadas tornaram-se mais complexas. Os resultados foram os mais diversos: algumas variáveis apareceram em alguns modelos, mas com pouca repetição. A variável que mais se destacou, nesse sentido, foi a variável pessoal gênero. Não há evidências na literatura de que essa variável exerça efeito preditivo nos modelos sobre mudança organizacional, embora os achados não sejam conclusivos (Oreg et atl, 2011; Vakola, Armenakis, \& Oreg, 2013); ainda assim, optou-se por apresentá-lo como referência para possíveis estudos futuros. O resultado encontrado pode ser derivado de características específicas da amostra do presente estudo que não foram mapeadas.

Uma segunda variável que se destacou foi ter participado da mudança ou não. Embora os resultados mapeados não tenham apresentado grande variabilidade, ou seja, os resultados apresentados encontram-se consolidados nos sujeitos do estudo empírico, é provável que variáveis do contexto e do processo da mudança tenham exercido influência na percepção ou não dos resultados planejados. A entrada da variável "ocupa cargo de chefia" no modelo empírico da pesquisa em conjunto com a variável "participou da mudança", e os resultados dos testes de 
diferença entre grupos - que identificaram diferenças na formação da variável "aderência à mudança” para essas duas variáveis - podem indicar que, em um contexto de alta aderência, o grau de envolvimento dos indivíduos com o processo possuem maior poder explicativo, em especial daqueles que ocupam cargos de gerencia, revelando relações complexas entre a disposição dos indivíduos e o contexto e processo da mudança organizacional, inclusive com interação de variáveis dos níveis individual, grupo e organizacional (Whelan-Berry, Gordon \& Hinings, 2003). Essa suposição encontra respaldo teórico em Valoka, Armenakis e Oreg (2013) e em Bisel e Barge (2010), e respaldo empírico em Buchanan, Addicott e Fitzgeral, (2007).

A hipótese 1 postulava que a variável aderência à mudança estaria positivamente relacionada com os resultados efetivos percebidos pelos funcionários da organização. Diante da discussão apresentada, concluiu-se que há evidências de que a variável aderência à mudança pode ter efeito positivo sobre a variação nos resultados percebidos; porém, esse efeito mostrou-se fraco no modelo empírico da presente dissertação, com apenas 3\% de variância explicada, e instável, com a entrada de variáveis contextuais. Uma possível explicação para esse efeito está na baixa variabilidade das variáveis-critério. Os 12 resultados utilizados foram escolhidos com base nos itens que mais se repetiram nos relatos dos entrevistados no Estudo 1. Como tratam-se de aspectos da mudança organizacional amplamente divulgados interna e externamente, esse aspecto pode ter contribuído para essa baixa variabilidade.

A hipótese 2 indicava que os componentes da estrutura organizacional influenciarão na relação entre aderência à mudança e resultados percebidos. No teste de moderações, obteve-se respostas ambíguas; em alguns modelos, houve efeito moderador sobre a relação, verificado pela diminuição da intensidade da relação entre as variáveis aderência à mudança e resultados percebidos; em outros, os componentes da estrutura apareceram como variáveis preditoras dos resultados percebidos. No modelo empírico desse trabalho, não foi encontrada relação de moderação. Esses achados, em conjunto com os resultados do Estudo 2, indicam que, para o presente estudo, a variável componentes da estrutura pode compartilhar variância com a variável aderência, especialmente pelo fato de que alguns dos resultados narrados pelos participantes do grupo focal dizem respeito a elementos da estrutura, conhecidos tradicionalmente por serem fatores de contexto (Armenakis \& Bedeian, 1999). Dois modelos empíricos (10 e 6) dão suporte a essa alternativa. Além disso, elementos como aspectos informais e sistemas de comunicação aparecem como fatores de contexto e que podem influenciar na formação das atitudes frente à 
mudança (Rafferty e Restubog, 2010). Ainda que tenham sido encontradas relações estatisticamente significativas, o respaldo para a hipótese de moderação é fraco; faz-se necessário investigar se os componentes da estrutura organizacional podem ser relevantes para compreender a formação da aderência à mudança enquanto representantes de variáveis de contexto da mudança (Voet, 2014). Porém, é importante salientar que a relação de moderação descrita nessa dissertação foi pouquíssimo estudada na literatura como um todo; dessa forma, os achados, ainda que modestos, apontam para caminho de pesquisa.

Nos testes de moderação, foram encontradas relações em que a variável "aderência à mudança" exerceu o papel de variável moderadora (modelos empíricos reduzidos relativos aos Resultados 11 e 12), o que gerou uma diminuição de intensidade nas relações obtidas nos modelos anteriores, sem o teste de moderação. Embora essa relação não fizesse parte do modelo teórico hipotetizado, trata-se de um achado importante para pesquisas futuras para investigar a atuação de variáveis relativas a atitudes, ou comportamentos, frente a mudança como moderadora (ou até mesmo de mediação) na relação entre variáveis de contexto ou conteúdo da mudança e resultados (tais como satisfação ou percepção de sucesso) ${ }^{3}$.

A terceira hipótese desse estudo procurou investigar se haveria diferenças estatisticamente significativas na formação da aderência à mudança entre os grupos das áreas fim e meio. Para tal, foi realizado o teste de Mann-Whitney, que concluiu não haver diferença significativa na formação da aderência à mudança entre os dois grupos. Porém, outras relações foram investigadas, em especial se o fato de um sujeito ter participado da mudança afetaria a formação da aderência, e se o fato de se ocupar uma posição de chefia teria efeito semelhante. Os achados do grupo focal ajudaram a lançar luz sobre essa relação, demonstrando que as oportunidades de engajamento dos sujeitos podem ter contribuído para a formação da aderência à mudança.

O teste forneceu evidencias de que é possível rejeitar a hipótese nula de que não houve diferenças, e abriu espaço para a investigação de possíveis fatores explicativos de atitudes frente à mudança relacionados a variáveis pessoais e profissionais, conforme hipotetizado por Oreg et al (2011), e cujos resultados são os mais variados.

\footnotetext{
${ }^{3}$ Como exemplos desses tipos de efeito, ainda que verificados com outras variáveis, citam-se o estudo de Santos, Neiva e Andrade-Melo (2013), que investigou o efeito mediador da variável percepção da mudança organizacional na relação entre clima organizacional e satisfação do cliente, e o de Oreg e Berson (2011), que investigou o papel moderador do comportamento de liderança transformacional na relação entre a resistência disposicional e a intenção de resistir à mudança.
} 
Ao longo do grupo focal, foi possível perceber que os participantes identificaram dois momentos do processo de mudança: o primeiro iniciou-se com a aprovação da Lei de Defesa da Concorrência e terminou com a mudança física de sede, quando as equipes passaram a ocupar um mesmo prédio, e o segundo iniciou-se a partir daí. Nesse segundo momento, houve a reconfiguração das equipes e uma nova onda de mudanças, voltadas para a revisão de fluxos de trabalho e criação de novos, "em um processo de tentativa e erro". O primeiro contou com um planejamento, ainda que não realizado em sua totalidade na percepção dos participantes; o segundo, foi sendo realizado e vivenciado no dia a dia.

O entrevistado demarcou o inicio do processo de mudança com as tratativas para elaboração do projeto de lei que deu origem a todo o processo, e a entrada em vigor da Lei 12.529/2011. Esse processo contemplou a revisão dos normativos e de fluxos de trabalho, especialmente na área fim, e contou com um planejamento de longo prazo para que fosse bemsucedido. Apontou ainda que não era possível prever quais alterações aconteceriam nos fluxos de trabalho, mas não chegou a configurar essas incertezas como uma segunda onda de mudança.

O fato de que, no modelo empírico da dissertação, foram justamente as variáveis sobre participação da mudança e ocupar cargo de chefia que apresentaram maior poder explicativo (com uma variância explicada de $25 \%$ ), pode indicar que fatores de contexto ganham importância em um contexto de atitudes positivas frente à mudança relativamente homogêneas, reforçando a hipótese de que processos cognitivos coletivos podem influenciar a formação de reações e de narrativas individuais sobre a mudança (Pieterse, Caniëls \& Homan, 2012). Um fator sobressaiuse, no Estudo 3, como possível antecedente da variável aderência à mudança: as oportunidades formais de engajamento que foram conferidas aos servidores. Essas oportunidades, traduzidas, por exemplo, na possibilidade de participação dos grupos de transição, foram compreendidas, pelos participantes do grupo focal e pelo entrevistado no Estudo 3, como formas de envolver as pessoas e construir uma visão compartilhada, gerando apoio (ou, pelo menos, não oposição) à mudança. Esses achados são consistentes com outros estudos na literatura de reações à mudança que tratam de comportamentos de apoio ao processo, tais como o estudo conduzido por Kim, Hornung e Rousseau (2011). 


\section{Considerações finais}

A presente dissertação procurou testar a relação entre aderência à mudança e resultados percebidos em um processo de mudança organizacional. A variável estrutura organizacional foi incluída pelo fato da estrutura perpassar a relação entre o indivíduo e a organização e, em certos casos, promover ou dificultar, o atingimento dos resultados desejados pelos agentes de mudança. Dessa forma, o objetivo de identificar, empiricamente, a influência da aderência à mudança sobre seus resultados percebidos, considerando-se o papel moderador de componentes da estrutura organizacional, foi cumprido.

Além disso, os objetivos específicos de construir e verificar evidências de validade de um instrumento de pesquisa sobre aderência à mudança, testar empiricamente a relação entre a aderência à mudança e resultado percebido da mudança organizacional foram atingidos. Considera-se que o objetivo específico de verificar empiricamente a influência dos componentes da estrutura organizacional na relação entre as variáveis aderência à mudança e resultado percebido também foi atingido por meio dos testes estatísticos nos modelos empíricos reduzidos apresentados no Capítulo 4, ainda que não tenha sido encontrada a relação de moderação hipotetizadas no Capítulo 2 para o modelo empírico completo da dissertação.

Depreende-se que esse trabalho contribuiu para o avanço teórico do estudo das referidas variáveis, uma vez que foi encontrada relação entre a variável aderência à mudança e os resultados percebidos, bem como foi proposta e testada empiricamente uma medida para aquela variável. Os achados adicionais - a relação de moderação da variável aderência à mudança identificada em alguns dos modelos empíricos reduzidos e a importância de variáveis pessoais e profissionais - impulsionam a investigação de relações ainda em fase de exploração na literatura de mudança organizacional. A segunda contribuição desse estudo é para a consolidação teórica na área ao procurar testar empiricamente as relações propostas pela literatura.

A seguir, serão apresentadas as recomendações práticas, as limitações e uma agenda de pesquisa proposta. 


\subsection{Recomendações práticas}

Os resultados de um processo de mudança organizacional não são óbvios, ainda que amplamente divulgados pela organização. No caso, nem todos os sujeitos relataram terem percebido os resultados apresentados, ainda que essa pesquisa tenha sido realizada quase 3 anos após o processo de mudança organizacional. Alguns resultados que decorreram do processo não foram planejados, e faz parte de toda mudança organizacional lidar com consequências inesperadas e, muitas vezes, não previstas. Além disso, nem todos os resultados são positivos para organização, o que derruba o mito de que mudanças planejadas sempre geram resultados positivos. Derivado desse ponto é a proposição de que a resistência à mudança pode ser um mecanismo de proteção contra resultados organizacionais negativos.

O processo de mudança organizacional tem um forte elemento subjetivo. Os sujeitos percebem os marcos e o tempo do processo de maneiras diferentes. A mudança pode ser percebida, inclusive, como um fluxo contínuo, com alguns momentos de ressignificação e cristalização dessas alterações - por exemplo, novas normas para sedimentar práticas já adotadas pela organização. Dessa forma, é importante criar visões compartilhadas como um facilitador desse processo.

A participação em um processo de mudança em que sejam criadas oportunidades de engajamento contribuem para reações positivas frente à mudança. No caso específico do Cade, parece que a comunicação com os funcionários e a oferta de oportunidades de engajamento contribuiu para a formação de uma visão positiva sobre a necessidade da mudança, o que pode ter fomentado comportamentos de engajamento.

Outra percepção importante é que o tempo de duração de um processo de mudança organizacional é imprevisível, ainda que ele seja planejado. Embora nos relatos do Estudo 1, o período entre a aprovação da Lei 12.529/2011 e sua entrada em vigor apareça como um marco temporal da duração do processo, foi reconhecido que, em verdade, a reestruturação do Cade demorou bem mais do que 6 meses - inclusive, alguns entrevistados apontam para uma segunda onda de ajustes, como se o processo ainda estivesse ocorrendo, ou ainda, que um segundo processo tivesse sido iniciado em maio de 2012.

Os achados do Estudo 3 demonstram que reações a mudança são mais complexas. Mais além, a primeira reação dos sujeitos do processo não necessariamente é a resistência; dessa 
forma, uma das funções dos agentes de mudança pode ser justamente identificar essas diferentes reações e capitalizar aquelas que são favoráveis à implementação, potencializando seu impacto positivo. Alem disso, os relatos apontam para a complexidade do fenômeno: há algumas pistas sobre quais fatores (especialmente atitudes frente à mudança) podem influenciar o sucesso de uma intervenção.

\subsection{Limitações}

A primeira limitação dessa dissertação é a composição da amostra com funcionários que não participaram em todas as etapas do processo de mudança. O ideal é que a amostra fosse composta apenas por funcionários que já eram parte do SBDC no início do processo; porém, como um número razoável já não estava no Cade, e diante da impossibilidade de contatá-los, foi necessário incluir pessoas que não participaram do processo na presente dissertação. Esse fato foi contornado, porém, pela comparação na formação de aderência à mudança entre participantes e não participantes do processo.

A segunda limitação diz respeito ao potencial de generalização dessa dissertação: esse estudo foi construído com base no caso do Cade, em um processo extenso de mudança organizacional. É natural que muitos aspectos tratados digam respeito apenas à situação do Cade; o desafio em estudos sobre mudança organizacional é equilibrar aspectos que possam ser generalizáveis (por exemplo, indícios de reações frente à mudança) com a profundidade necessária para compreender um processo específico. Há também necessidade de mais verificações empíricas da escala de aderência à mudança proposta, de forma que ela se constitua como instrumento de pesquisa aplicável a diferentes contextos, uma vez que ela foi criada no contexto de análise do processo de mudança organizacional do Cade.

A pouca variabilidade dos resultados mapeados gerou dificuldades para a identificação de possíveis efeitos, uma vez que a variância a ser explicada era pequena. Essa constatação aponta para a necessidade de pesquisa de outros aspectos organizacionais ao se replicar o modelo de pesquisa proposto, ou até mesmo a utilização de indicadores duros de sucesso de mudança organizacional.

Uma terceira limitação diz respeito a existência de vieses de resposta, tanto por tratar-se de medidas de auto-relato quanto pela possibilidade do fenômeno da desejabilidade social. O fato do objeto dessa dissertação foi a de um processo já ocorrido, o que pode gerar uma avaliação 
positiva exacerbada dos resultados obtidos e uma necessidade de avaliação positiva da contribuição individual para o sucesso do processo

\subsection{Agenda de pesquisa}

Como proposta para agenda de pesquisa, sugere-se a aplicação do instrumento de aderência à mudança criado como variável critério, com o objetivo de verificar quais fatores interferem na formação de atitudes frente à mudança em um processo de mudança organizacional. Esse trabalho oferece alguns elementos, tais como componentes da estrutura organizacional, oportunidade de envolvimento dos funcionários e fortalecimento dos canais de comunicação. Outras variáveis surgiram ao longo desse trabalho, em especial ao realizar-se a triangulação entre os estudos 1, 2 e 3, tais como a variável comprometimento e elementos da cultura organizacional. Dessa forma, sugere-se que estudos futuros investiguem essas variáveis.

Além disso, é importante salientar a diferença nas estatísticas da variável aderência a mudança entre ocupantes de cargos de chefia ou não. Essa diferença aponta para a importância das lideranças no processo de mudança, levando ao conceito de agente de mudanças.

A replicação do modelo proposto é importante para investigar mais as relações entre as variáveis e eliminar outras explicações plausíveis para os efeitos observados, permitindo que as conclusões sejam generalizáveis. A replicação é de especial importância, dada a dispersão teórica da área e a falta de estudos empíricos quantitativos, especialmente na produção nacional. Esse cenário tem mudado; ainda assim, é fato de que as relações entre as variáveis ainda não são claras. Os estudos presentes no referencial teórico da presente dissertação teorizam sobre alguns possíveis preditores, mas ainda há poucos estudos empíricos que testem essas relações hipotetizadas. Ademais, a conjugação de métodos qualitativos e quantitativos podem enriquecer estudos que tratam de mudança organizacional, uma vez que se tratam de fenômenos particulares, que variam de acordo com as organizações e com os diferentes momentos dentro de uma mesma organização.

O modelo de pesquisa se beneficiaria da realização de estudos longitudinais para verificar o impacto de ações de preparação para processos de mudança na atitude frente a mudança dos envolvidos. Em verdade, grande parte das hipóteses teóricas dizem respeito ao fomento de 
reações positivas nas organizações, suas equipes e os indivíduos que as compõe. Essa iniciativa pode auxiliar na compreensão de quais medidas são efetivas para determinadas organizações, de forma que o processo de mudança seja apoiado e bem sucedido, do ponto de vista tanto de implementadores quanto de sujeitos do processo;

O campo também pode se beneficiar da aplicação de técnicas estatísticas mais sofisticadas para pesquisas empíricas. O fato de que componentes da estrutura organizacional aparecem como variável explicativa podem indicar interações entre variáveis de diferentes níveis para compreensão dos processos, o que abre caminho, por exemplo, para a utilização da modelagem multinível.

Uma relação inexplorada nessa dissertação foi a comparação do grau de sucesso de implementação de um processo de mudança organizacional entre organizações públicas e privadas. Há um senso comum de que a mudança organizacional seria mais difícil de ser implementada, em termos de resultados atingidos, em uma organização públicas, devido especialmente à uma maior resistência. O presente trabalho apresenta um exemplo contrafactual, tanto na formação de atitude positiva frente à mudança, quanto em relação ao sucesso de um grande processo de mudança organizacional, mas essa hipótese ainda carece de mais estudos. Um segundo pólo de pesquisas é a conexão entre a extensão das mudanças implementadas e as reações evocadas, pois há relações hipotetizadas de que os elementos afetados pelo processo geram desafios e conseqüências diferentes para a implementação - por exemplo, as diferenças entre mudanças transacionais e transformais.

Por fim, pode ser benéfico a criação de uma escala com itens relativos a atitudes negativas frente à mudança, de forma a fazer um contraponto com as atitudes de aderência. Essa adição pode ajudar a verificar se um baixo nível de aderência à mudança traduz-se em resistência, ou em um comportamento ambíguo frente ao fenômeno da mudança organizacional. Essa distinção é importante, pois um dos principais argumentos teóricos para a diversidade de reações frente à mudança é o de que essas reações não se expressam em dois pólos opostos. 


\section{REFERÊNCIAS BIBLIOGRÁFICAS}

Abbad, G., \& Torres, C. V. (2002). Regressão Múltipla Stepwise e Hierárquica em Psicologia Organizacional: aplicações, problemas e soluções. Estudos de Psicologia, 7 (Número Especial), 19-29.

Agresti, A., \& Finlay, B. (2012). Métodos estatísticos para as ciências sociais. Porto Alegre: Penso.

Armenakis, A. A. \& Bedeian, A. G. (1999) Organizational change: a review of theory and research in the 1990s. Journal of Management, 25 (3), 293-315.

Avey, J. B., Wernsing, T. S. , \& Luthans, F. (2008) Can Positive Employees Help Positive Organizational Change? The Jornal of Applied Behavioral Science, 44(1), 48-70.

Banco Interamericano de Desenvolvimento (1997). Evaluación: una herramienta de gestión para mejorar el desempeño de los proyectos. Disponível em http://www.cedet.edu.ar/Archivos/BibliotecasArchivos/72BID-OVE\%20\%20Marco\%20L\%C3\%B3gico.pdf. Acesso em 15 de maio de 2014.

Bardin, L. (2011). Análise de Conteúdo (6 $6^{\mathrm{a}}$ ed.). Lisboa: Edições 70.

Barends, E., Janssen, B., ten Have, W., \& ten Have, S. (2014). Effects of Change Interventions: What Kind of Evidence Do We Really Have? The Journal of Applied Behavioral Science, 50(1), 5-27.

Beech, N., \& Johnson, P. (2005). "Discourses of disrupted identities in the practice of strategic change. Journal of Organizational Change Management, 18 (1), 31-47

Ben-Gal, H. C., \& Tzafrir, S. (2011). Consultant-client relationship: one of the secrets to effective organizational change? Journal of Organizational Change, 24(5), 662-679.

Bertussi, N. L. (2012). Componentes da estrutura organizacional e desempenho de núcleos setoriais empresariais: estudo no núcleo estadual de automecânicas de santa catarina. Dissertaçao de Mestrado, Universidade de Brasília, DF, Brasil.

Binci, D., Cerruti, C., \& Donnarumma, S. A. (2012). Resistance in HROs, setback or resource? Journal of Organizational Change Management, 25 (6), 867-882.

Bouckenooghe, D. (2010). Positioning change's recipients attitudes toward change in the organizational change literature. Journal of Applied Behavioral Science, 46(4), 500-531.

Burke, W. W. (2011). Organizational change: theory and practice ( $3^{\mathrm{a}}$ ed., cap. 1, p. 1-18). Washington D. C.: Sage Publications. 
Decreto n. 7.778/2012 (2012). Aprova a Estrutura Regimental e o Quadro Demonstrativo dos Cargos em Comissão do Conselho Administrativo de Defesa Econômica - CADE; remaneja cargos em comissão e funções de confiança; altera os Decretos $n^{\circ} 6.061$, de 15 de

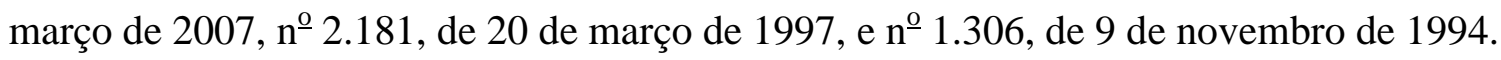

DeCelles, K. A., Tesluk, P. E., \& Taxman, F. S. (2013). A Field Investigation of Multilevel Cynicism Toward Change. Organization Science, 24(1), 154-171.

Dimaggio, P., \& Powell, W. (2007). Jaula de ferro revisitada: isomorfismo institucional e racionalidade coletiva nos campos organizacionais. In M. P. Caldas, \& C. O. Bertero (Coords.). Teoria das organizações (pp. 117-142). São Paulo: Atlas.

Dobrev, S. D., Kim, T. Y., \& Carroll, G. R. (2003). Shifting Gears, Shifting Niches: Organizational Inertia and Change in the Evolution of the U.S. Automobile Industry, 18851981. Organization Science, 14(3), 264-282

Donaldson, S. I. \& Grant-Vallone, E. J. (2002). Understanding self-report bias in organizational behavior research. Journal of Business and Psychology, 17 (2), 245-260.

Domingos, S. G. \& Neiva, E. R. (2014). Percepção dos Funcionários sobre Mudanças Transacionais e Transformacionais em uma Organização Pública. Revista de Administração Contemporânea, 18(2), 118-138.

Escola Nacional de Administração Pública (2014). Ações premiadas no 18 Concurso de Inovação da Gestão Pública Federal. Brasília: ENAP

Ferreira, M. P. \& Armagan, S. (2011). Using Social Networks Theory as a Complementary Perspective to the Study of Organizational Change. Brazilian Administrative Review, 8(2), 168-184

Ford, J. D., Ford, L. W. \& D'Amelio, A. (2008) Resistance to change: the rest of the history. Academy of Management Review, 33(2), p. 362-377

Fugate, M. (2013). Capturing the positive experience of change: antecedents, processes and consequences. In S. Oreg, A. Michel \& R. T. By (Eds.). The psychology of organizational change: viewing change from employee's perspective (pp. 15-40). New York: Cambridge University Press 
Gaskell, G (2007). Entrevistas individuais e grupais. In Bauer, M. W.; \& Gaskell, G. Pesquisa qualitativa com texto, imagem e som (cap. 3, p. 64 a 89). Rio de Janeiro: Editora Vozes.

Greenwood, R. E., \& Hinings, C. R. (1996). Understanding radical organizational change: bringing together the old and the new institutionalism. Academy of Management Review, 21(4), 1022-1054.

Godoi, C. K., \& Mattos, P. L. C. L. (2010). Entrevista qualitativa: instrumento de pesquisa e evento dialógico. In C. K. Godoi, R. Bandeira-de-Mello, \& A. B. Silva (Orgs.). Pesquisa Qualitativa em Estudos Organizacionais: paradigmas, estratégias e métodos (cap. 10, pp. 301-324). São Paulo: Saraiva.

Guiette, A., \& Vandenbempt, K. (2013). Exploring team mental model dynamics during strategic change implementation in professional service organizations: a sensemaking perspective. European Management Journal, 31, 728-744.

Hair Jr., J. F., Black, W. C., Babin, B. J., Anderson, R. E., \& Tatham, R. L. (2009). Análise Multivariada de Dados. Porto Alegre: Bookman.

Heugens, P.; Lander, M. (2009). Structure! Agency! (and Other Quarrels): a meta-analysis of institutional theories of organization. Academy of Management Journal, 52 (1), 61-85.

Jacobs, G.; Keegan, A. \& Christe-Zeyse, J. (2006). The fatal smirk Insider accounts of organizational change processes in a police organization. Journal of Organizational Change Management, 19 (2), p. 173-191.

Kim, T. G., Hornung, S., \& Rousseau, D. M. (2011). Change-supportive employee behavior: antecedents and the moderating role of rime. Journal of Management, 37(6), 1664-1693.

Kotter, J. P. (1995). Leading change - why transformational efforts fail. Harvard Business Review, 73 (2), 58-67.

Kotter, J. P., \& Schlesinger, L. A. (2008). Choosing strategies for change. Harvard Business Review, 57(2)

Hannan, M.T. \& Freeman, J. (1984). Structural inertia and organizational change. American Sociologial Review, 49, 149-164. 
Hannan, M.T. \& Freeman, J. (2007). Ecologia de população das organizações. In M.P. Caldas \& C.O. Bertero (Coords.). Teoria das organizações (pp. 154-190). São Paulo: Atlas.

Hannan. M. T., Pólos, L., \& Carroll, G. R. (2003). Cascading organizational change. Organization Science, 463-482

Hernandez, J. M. \& Caldas, M. (2001). Resistência à mudança: uma revisão crítica. Revista de Administração de Empresas, 41 (2), 31-45.

Hertog, F. D., Iterson A. V., \& Mari, C. (2010). Does HRM really matter in bringing about strategic change? Comparative action research in ten European steel firms. European Management Journal, 28, 14- 24

Kuntz, J. R. C., \& Gomes, J. F. S. (2012). Transformational change in organisations: a selfregulation approach. Journal of Organizational Change Management, 25(1), 143-162

Lei n. 12.529, 30 de novembro de 2011 (2011). Estrutura o Sistema Brasileiro de Defesa da Concorrência; dispõe sobre a prevenção e repressão às infrações contra a ordem econômica; altera a Lei no 8.137, de 27 de dezembro de 1990, o Decreto-Lei no 3.689, de 3 de outubro de 1941 - Código de Processo Penal, e a Lei no 7.347, de 24 de julho de 1985; revoga dispositivos da Lei no 8.884, de 11 de junho de 1994, e a Lei no 9.781, de 19 de janeiro de 1999; e dá outras providências. Diário Oficial da União. Brasília, DF: Presidência da República

Lima, S. M. V., \& Bressan, C. L. (2003). Mudança organizacional: uma introdução. In S. M. V. Lima (Org.). Mudança organizacional: teoria e gestão (pp. 17-61). São Paulo: Editora FGV.

Loiola, E., Bastos, A. V. B., Queiroz, N., \& Silva, T. D. (2011). Dimensões básicas de análise das organizações. In Zanelli, J. C., Borges-Andrade, J. E., Bastos, A. V. B. (Org). Psicologia, Organizações e Trabalho no Brasil. (p. 91-143). Porto Alegre: Artmed.

Lines, R. (2005). The structure and function of attitudes towards organizational change. Human Resources Development Review, 4 (1), 8-32

Meyer, J. W., \& Rowan, B. (1977) Institutionalized organizations: Formal structure as myth and ceremony. American Journal of Sociology, 83, 340-363 
Meyer, P., \& Hamilton, L. K. (2013). Commitment to organizational change: theory, research, principle, and practices. In S. Oreg, A. Michel \& R. T. By (Eds.). The psychology of organizational change: viewing change from employee's perspective (pp. 43-64). New York: Cambridge University Press

Mowday, R. T., \& Sutton, R. I. (1993). Organizational behavior: linking individuals and groups to organizational contexts. Annual Review of Psychology, 44, p. 195-229.

Neiva, E. R. (2004). Percepção de mudança organizacional: o papel das atitudes e das características organizacionais. Tese de Doutorado, Universidade de Brasília, DF, Brasil.

Neiva, E. R. \& Pantoja, M. J. (2011). Aprendizagem e mudança organizacional: das relações entre atitudes frente à mudança e estratégias de aprendizagem no trabalho. Revista Interamericana de Psicologia, 45(2), 145-156.

Neiva, E. R., \& Paz, M. G. T. (2007). Percepção de mudança organizacional: um estudo em uma organização pública brasileira. Revista de Administração Contemporânea, 11(1), p. 31-52

Nye, C. D., Brummel, B. J., \& Drasgrow, F. (2010). Too good to be true? Understanding change in organizational outcomes. Journal of Management, 36 (6), p. 1555-1577

Oliveira, D. P. R. de (2011). Organizações, sistemas e métodos (20ª ed.). São Paulo: Atlas.

Oliveira, M., \& Freitas, H. (2010) Focus group: instrumentalizando o seu planejamento. In C. K. Godoi, R. Bandeira-de-Mello, \& A. B. Silva (Orgs.). Pesquisa Qualitativa em Estudos Organizacionais: paradigmas, estratégias e métodos (cap. 11, pp. 325-246). São Paulo: Saraiva.

Oreg, S., \& Berson, Y. (2011). Leadership and employee`s reaction to change: the role of leaders`personal attributes and transformational leadership style. Personnel Psychology, 64, 627-659.

Oreg, S., Vakola, M., \& Armenakis, A. (2011) Change recipient's reaction to organizational change: a 60-year review of quantitative studies. Journal of Applied Behavioral Science, 47(4), p. 461-524.

Pasquali, L. (2005). Análise fatorial para pesquisadores, Brasilia- DF; Editora Universidade de Brasília. 
Piderit, S. K. (2000). Rethinking resistance and recognizing ambivalence: a multidimensional view of attitudes toward an organizational change. Academy of Management Review, 25 (4), 783-794

Pieterse, J. H., Caniëls, M. C. J., \& Homan, T. (2012). Professional discourses and resistance to change. Journal of Organizational Change Management, 25 (6), p. 798-818

Podsakoff, P. M., MacKenzie, S. B., \& Podsakoff, N. P. (2012) Sources of method bias in social science research and recommentadions on how to control it. Annual Review Psychology, $63,539-569$.

Rafferty, A., \& Restubog, S. L. D. (2010). The Impact of Change Process and Context on Change Reactions and Turnover During a Merger. Journal of Management, 36 (5), 1309-1338.

Rafferty, A., Jimmieson, N. L., \& Armenakis, A. A. (2013). Change readiness: a multilevel review. Journal of Management, 39 (1), 110-135.

Richardson, R. J. (2012). Pesquisa Social: Métodos e Técnicas. São Paulo: Atlas.

Rodrigues, A., Assmar, E. M. L., \& e Jablonski, B. (2009). Psicologia Social (27 a ed., cap. 4, p. 81-132). Rio de Janeiro: Vozes.

Santos, J. N., Neiva, E. R. \& Andrade-Melo, E. A, (2013). Relação entre clima organizacional, percepção de mudança organizacional e satisfação do cliente. Psicologia: Teoria e Pesquisa, 29(1), 31-39.

Scorsolini-Comina, F, \& Santos, M. A. (2010) Psicologia positiva e os instrumentos de avaliação no contex to brasileiro. Psicologia: Reflexão e Crítica, 23(3), 440-448.

Scott, R. W. (2003). Organizations: rational, natural and open systems (5a. ed). New Jersey: Prentice Hall.

Seo, M., Taylor, S. H., Hill, N. S., Zhang, X., Tesluk, P. E., \& Lorinkova, N. M. (2012). The role of affect and leadership during organizational change. Personnel Psychology, 65, 121-165.

Smissen, S., Schalk, R., \& Freese, C. (2013). Organizational change and the psychological contract: how change influences the perceived fullfilment of obligations. Journal of Organizational Change Management, 26(6), 1071-1090. 
Sorge \& Van Witteloostuijn, (2011). Consultant-client relationship: one of the secrets to effective organizational change? Journal of Organizational Change Management, (24) 5, 662-679.

Suchman, M. (1995). Managing legitimacy: strategic and institutional approaches. Academy of Management Review, 20 (3), 571-610.

Tabachnick, B. G., \& Fidell, L. S. (2007). Using Multivariates Statistics (5a ed). Boston: Pearson Education.

Tsoukas, H. \& Chia. R; (2002). On organization becoming: rethinking organizational change. Organization Science, 13 (5), 567-582.

Tsang, E. W. K., \& Zahra, S. A. (2008). Organizational unlearning. Human Relations, 61 (10), $1435-1462$

Vakola, M., Armenakis, A., \& Oreg, S. (2013). Reactions to organizational change from an individual differences perspective: a review of empirical research. In S. Oreg, A. Michel \& R. T. By (Eds.). The psychology of organizational change: viewing change from employee’s perspective (pp. 95-122). New York: Cambridge University Press

Van de Ven. A. H. \& Poole, M. S. (2005). Alternative approaches for studying organizational change. Organization Studies, 26 (9), 1377-1404.

Voet, J. van der (2014). The effectiveness and specificity of change management in a public organization: Transformational leadership and a bureaucratic organizational structure. European Management Journal. 32 (3), 373-382.

(Whelan-Berry, K. S., Gordon, J. R., \& Hinings, C. R. (2003). Strengthening Organizational Change Processes: Recommendations and Implications From a Multilevel Analysis. The Journal of Applied Behavioral Science, 39, 186-207.

Weick, K. E., \& Quinn, R. E. (1999). Organizational Change and Development. Annual Review of Psychology, 50, 361-386.

Weiner, B. J. (2009). A theory of organizational readiness for change. Implementation Science, 4(67), doi:10.1186/1748-5908-4-67 


\section{ANEXO I - Medida de aderência à mudança}

Adaptado de Voet (2014)

Prezado(a) Participante,

Este questionário faz parte de uma pesquisa para identificar sua percepção sobre os vários tipos de ideias que você e as pessoas podem ter tido na época em que ocorreu a implementação do Novo Cade, em maio/junho de 2012. O período em questão refere-se ao que ocorreu antes da entrada em vigor da Lei $n^{\circ} 12.529 / 2011$, e que envolveu a preparação para a mudança de sede física, revisão do regimento interno, novos processos de trabalho, ampliação da estrutura de cargos do Cade e entrada de novas pessoas na equipe.

Importa-nos identificar o seu posicionamento sobre o processo de preparação do Cade para a transição ocorrida em 2012, bem como a sua percepção sobre as características do Cade que se modificaram ao longo do tempo. Caso você não esteja no Cade desde maio/2012, responda de acordo com a sua percepção sobre esse processo de transição para o novo Cade.

Sua tarefa consiste em ler e avaliar cada um dos itens que lhe for apresentado(a). A escala varia de 1 (discordo totalmente com a afirmativa do item) a 10 (concordo totalmente com a afirmativa do item). Não existe resposta certa ou errada. Sua resposta deve exprimir exatamente o que você pensa sobre cada afirmativa. Por favor, procure não deixar nenhuma questão em branco.

Nos itens em que a escala varia entre Sim e Não, aponte se você concorda ou discorda da afirmação apresentada.

\section{Escolha qualquer ponto da escala que melhor lhe convier de acordo com sua análise e julgamento do item.}

Esse questionário é parte de pesquisa acadêmica para mestrado em administração. Sua contribuição é de extrema valia à realização deste trabalho acadêmico. Por favor, seja sincero ao dar suas respostas. Os dados serão analisados conjuntamente, não individualmente. O sigilo das suas respostas está totalmente garantido.

Obrigado, desde já, pela sua importante participação nesta pesquisa! Qualquer dúvida, favor contatar mariane.cortat@gmail.com.

1. As informações sobre a mudança foram comunicadas a contento.

(1) (2) (3) (4) (5) (6) (7) (8) (9) (10)

2. O Cade preocupou-se em preparar as pessoas para a mudança que iria acontecer

(1) (2) (3) (4) (5) (6) (7) (8) (9) (10)

3. A implementação da mudança contou com a participação de todo o Cade

(1) (2) (3) (4) (5) (6) (7) (8) (9) (10)

4. Eu sabia do resultado esperado antes mesmo da mudança ser iniciada no Cade

(1) (2) (3) (4) (5) (6) (7) (8) (9) (10)

5. A mudança afetou o Cade como um todo.

(1) (2) (3) (4) (5) (6) (7) (8) (9) (10) 
6. As principais mudanças que foram implementadas estavam claras para mim.

(1) (2) (3) (4) (5) (6) (7) (8) (9) (1)

7. A implementação da mudança foi a melhor solução para os problemas enfrentados pelo

(1) (2) (3) (4) (5) (6) (7) (8) (9) (10) Cade à época.

8. A implementação da mudança apresentada foi necessária para o Cade

(1) (2) (3) (4) (5) (6) (7) (8) (9) (10)

9. Acredito que a mudança beneficiou o Cade como um todo

(1) (2) (3) (4) (5) (6) (7) (8) (9) (1)

10. A mudança contribuiu para a melhoria do resultado da atuação do Cade

(1) (2) (3) (4) (5) (6) (7) (8) (9) (10)

11. O meu engajamento foi importante para a implementação do Novo Cade

(1) (2) (3) (4) (5) (6) (7) (8) (9) (10)

12. O engajamento das pessoas da minha unidade foi importante para a implementação do

(1) (2) (3) (4) (5) (6) (7) (8) (9) (10) Novo Cade

13. A mudança despertou emoções positivas em mim

(1) (2) (3) (4) (5) (6) (7) (8) (9) (10)

14. Senti-me motivado com a mudança dada sua implementação no Novo Cade

(1) (2) (3) (4) (5) (6) (7) (8) (9) (10)

15. As pessoas à minha volta demonstravam entusiasmo para mudar

(1) (2) (3) (4) (5) (6) (7) (8) (9) (10)

16. As pessoas aqui no Cade reagiram bem à mudança

(1) (2) (3) (4) (5) (6) (7) (8) (9) (10)

17. Eu procurei convencer os outros dos benefícios das mudanças implementadas no Cade

(1) (2) (3) (4) (5) (6) (7) (8) (9) (10)

18. Eu empreendi esforços para atingir os resultados esperados do processo de mudança no

(1) (2) (3) (4) (5) (6) (7) (8) (9) (10) Cade

19. Eu agi no sentido de reduzir a resistência das outras pessoas em relação às mudanças

(1) (2) (3) (4) (5) (6)(7)(8) (9) (10) no Cade

20. Eu fiz o que estava ao meu alcance para garantir o sucesso da implementação do Novo

(1) (2) (3) (4) (5) (6) (7) (8) (9) (1) Cade

21. As pessoas à minha volta fizeram o que estava ao alcance delas para garantir a (1) (2) (3)(4)(5)(6) (7) (8) (9) (1) implementação do Novo Cade 


\section{ANEXO II - Resultados percebidos}

1. Você trabalhava no Cade antes de maio de 2012?

( ) Sim ( )Não

2. Você trabalhava na Secretaria de Direito Econômico (SDE/MJ) ou na Secretaria ( ) Sim ( )Não de Acompanhamento Econômico (SEAE?MF) antes de maio de 2012?

3. O Cade passou a contar, a partir de maio de 2012, com novos processos de ( ) Sim ( )Não trabalho na área finalística

4. O Cade passou a contar, a partir de maio de 2012, com novos processos de ( )Sim ( )Não trabalho na área de suporte

5. O Cade passou a contar, a partir de maio de 2012, com um novo processo de ( )Sim ( )Não análise de atos de concentração. Agora, as empresas têm de comunicar uma fusão antes da conclusão do negócio.

6. Os prazos processuais mudaram após o processo de mudança organizacional ( )Sim ( )Não iniciado em maio de 2012, e isso diminuiu o tempo que se leva para analisar um Ato de Concentração (fusão e aquisição entre empresas)

7. Os prazos processuais mudaram após o processo de mudança organizacional ( )Sim ( )Não iniciado em maio de 2012, e isso diminuiu o tempo que se leva para analisar um processo punitivo (processo de análise de uma conduta unilateral anticompetitiva ou de um cartel)

8. O Cade possui uma nova estrutura organizacional. Essa nova estrutura mudou as ( ) Sim ( )Não responsabilidades e as demandas da área em que eu trabalho

9. O Cade possui uma nova estrutura organizacional. Essa nova estrutura demandou ( )Sim ( )Não a mudança na forma como as áreas trabalham.

10. As incorporação de novas atribuições e novos processos de trabalho na área fim ( )Sim ( )Não repercutiram nas áreas de suporte.

11. As áreas de suporte possuem novas responsabilidades e formas de trabalho por ( ) $\operatorname{Sim~(~)Não~}$ conta das alterações ocorridas na área fim.

12. A nova estrutura organizacional do Cade permitiu a melhoria dos seus resultados ( )Sim ( )Não organizacionais.

13. As pessoas têm menos disposição para cooperar na solução de problemas hoje. $\quad$ ( )Sim ( )Não

14. As unidades do Cade são mais distantes umas das outras do que antes da ( )Sim ( )Não mudança. 


\title{
ANEXO III - Escala de Percepção de Componentes de Estrutura Organizacional
}

\author{
Coelho Jr., Quadros, Oliveira e Maciel (sem data)
}

\section{Prezado(a) Participante,}

Este questionário visa identificar sua percepção sobre como funciona sua organização de trabalho. Mais especificamente, pretende verificar o que você acha sobre sua estrutura de trabalho, em termos das responsabilidades que são atribuídas a você, os processos de tomada de decisão e outros aspectos típicos das suas rotina de trabalho.

Sua tarefa consiste em ler e avaliar cada um dos itens que lhe for apresentado(a). A escala varia de 1 (discordo totalmente com a afirmativa do item) a 10 (concordo totalmente com a afirmativa do item).

Não existe resposta certa ou errada. Sua resposta deve exprimir exatamente o que você pensa sobre cada afirmativa. Por favor, procure não deixar nenhuma questão em branco.

Escolha qualquer ponto da escala que melhor lhe convier, de acordo com sua análise e julgamento da afirmativa.

Sua contribuição é de extrema valia à realização deste trabalho. Por favor, seja sincero ao dar suas respostas. Os dados serão analisados conjuntamente, não individualmente. O sigilo das suas respostas está totalmente garantido.

Obrigada, desde já, pela sua importante participação nesta pesquisa! Qualquer dúvida, favor contatar mariane.cortat@gmail.com.

1. Em meu local de trabalho há uma definição formal sobre quem faz o quê.

(1) (2) (3) (4) (5) (6) (7) (8) (9) (10)

2. Aqui, a autoridade formal é claramente estabelecida.

(1) (2) (3) (4) (5) (6) (7) (8) (9) (10)

3. As tarefas e responsabilidades de cada um são prescritas e realizadas com eficiência.

(1) (2) (3) (4) (5) (6) (7) (8) (9) (10)

4. Existe (m) liderança(s) informal (is) que são mais influente(s) que meu chefe(s).

(1) (2) (3) (4) (5) (6) (7) (8) (9) (10)

5. A comunicação informal (colegas, rádio corredor e outros) é mais efetiva que a formal (1) (2) (3) (4) (5) (6) (7) (8) (9) (10) (murais, jornais e outros).

6. Em meu setor, muitos acham que mandam.

(1) (2) (3) (4) (5) (6) (7) (8) (9) (10)

7. Aqui, a hierarquia é respeitada.

(1) (2) (3) (4) (5) (6) (7) (8) (9) (10)

8. Decisões mais simples de meu cargo, de caráter rotineiro, podem ser tomadas sem o (1) (2) (3) (4) (5) (6) (7) (8) (9) (10) conhecimento do chefe.

9. O conhecimento de como funciona a estrutura desta Organização é importante para o

(1) (2) (3) (4) (5) (6) (7) (8) (9) (10) 
meu desempenho.

10. A eficiência de uma organização depende da integração entre as pessoas que nela (1) (2) (3)(4)(5)(6) (7)(8)(9) (1) trabalham.

11. Características pessoais são levadas em conta pelo meu chefe ao avaliar meu (1) (2) (3)(4)(5)(6) (7)(8)(9) (1) desempenho.

12. Minha rotina de trabalho favorece o desenvolvimento de minhas habilidades e (1) (2) (3)(4)(5) (6) (7) (8) (9) (10) conhecimentos.

13. Acredito que muitos, aqui dentro, acham que mandam, mesmo sem serem chefes (1) (2) (3)(4) (5) (6) (7) (8) (9) (1) formalmente estabelecidos.

14. Meu chefe leva em conta meus conhecimentos e habilidades ao planejar e avaliar meu

(1) (2) (3) (4) (5) (6) (7) (8) (9) (10) desempenho.

15. Meus colegas respeitam a hierarquia em meu setor ou local de trabalho.

(1) (2) (3) (4) (5) (6) (7) (8) (9) (10)

16. Os recursos existentes (tecnológicos, financeiros e materiais) são suficientes à (1) (2) (3)(4)(5) (6) (7) (8) (9) (10) realização de meu trabalho.

17. As atividades que eu executo aqui são alinhadas aos meus conhecimentos e (1) (2) (3) (4)(5) (6)(7)(8)(9) (1) habilidades.

18. Em meu setor, há amplitude de controle (número de subordinados que um chefe (1) (2) (3)(4) (5) (6) (7) (8) (9) (1) supervisiona de maneira efetiva e adequada) necessária ao desempenho competente.

19. Nesta Organização, os níveis hierárquicos são claramente definidos.

(1) (2) (3) (4) (5) (6) (7) (8) (9) (10)

20. Conhecimentos e habilidades são levados em conta pelo meu chefe ao planejar minhas

(1) (2) (3) (4) (5) (6) (7) (8) (9) (10) rotinas.

21. Na minha organização há abertura para comunicação entre os profissionais e entre as

(1) (2) (3) (4) (5) (6) (7) (8) (9) (10) unidades organizacionais.

22. Em meu setor há acompanhamento, por parte de meu chefe, necessário ao meu bom

(1) (2) (3) (4) (5) (6) (7) (8) (9) (10) desempenho.

23. Meu chefe toma decisões rápidas e bem fundamentadas.

(1) (2) (3) (4) (5) (6) (7) (8) (9) (10)

24. Tenho disponível um manual de atribuições e responsabilidades, que acesso quando eu (1) (2) (3) (4) (5) (6) (7) (8) (9) (1) tiver interesse.

25. Tenho autonomia para tomar decisões de qualquer complexidade.

(1) (2) (3) (4) (5) (6) (7) (8) (9) (10)

26. A tomada de decisão, em meu setor, é feita como resultado da análise de dados e (1) (2) (3) (4) (5) (6) (7) (8) (9) (10) informações disponíveis. 
27. A comunicação formal se dá via e-mail, avisos contidos em murais, na intranet e/ou $\quad$ (1) (2) (3) (4) (5) (6) (7) (8) (9) (10) em outras fontes de informações gerenciadas.

28. A autoridade (o direito estabelecido de se designar o quê, como, por quem, quando e (1) (2) (3) (4) (5) (6) (7) (8) (9) (1) por quanto, deve ser realizado) é corretamente exercida em meu local de trabalho.

29. O chefe que é participativo tem maiores possibilidades de estabelecer uma autoridade $\quad$ (1) (2) (3) (4) (5) (6) (7) (8) (9) (10) eficaz.

30. Mais de uma pessoa dando comandos a mim gera efeitos positivos sobre o meu (1) (2) (3) (4) (5) (6) (7) (8) (9) (10) desempenho.

31. Existem, aqui, práticas adotadas pelo meu chefe relacionadas à gestão (planejamento, (1) (2) (3) (4) (5) (6) (7) (8) (9) (10) monitoramento, avaliação e revisão) efetiva do meu desempenho.

32. Julgo que sou bem aproveitado em comparação aos conhecimentos e habilidades que $\quad$ (1) (2) (3) (4) (5) (6) (7) (8) (9) (10) possuo.

$\begin{array}{lll}\text { 33. A estrutura organizacional atende às necessidades de comunicação nesta Organização. } & \text { (1) (2) (3) (4) (5) (6) (7) (8) (9) (10) }\end{array}$

34. A transmissão de informações é feita sem ruídos (barreiras) em minha Organização. $\quad$ (1) (2) (3) (4) (5) (6) (7) (8) (9) (10)

35. A definição das rotinas de trabalho é baseada nos conhecimentos e habilidades dos $\quad$ (1) (2) (3) (4) (5) (6) (7) (8) (9) (10) funcionários.

36. Aqui, valorizam-se práticas relacionadas ao desenvolvimento de conhecimentos e (1) (2) (3) (4) (5) (6) (7) (8) (9) (10) habilidades dos funcionários.

37. As pessoas que aqui trabalham têm competência para estarem aqui.

(1) (2) (3) (4) (5) (6) (7) (8) (9) (10)

38. Os chefes, aqui, têm um número adequado de subordinados para supervisionarem.

(1) (2) (3) (4) (5) (6) (7) (8) (9) (10) 


\section{ANEXO IV - Conjunto de Informações sócio-demográficas}

\section{Idade}
( ) Menos de 20 anos
( ) 20 a 24 anos
( ) 25 a 29 anos
( ) 30 a 34 anos
( ) 35 a 39 anos
( ) 40 a 44 anos
( ) Acima de 45 anos

\section{Gênero}

( ) Feminino ( ) Masculino

Escolaridade (assinale o maior grau de instrução até o momento)

( ) Ensino Médio incompleto

( ) Ensino Médio completo

( ) Superior Incompleto
( ) Superior Completo

( ) Pós-Graduação (Especialização/Mestrado/Doutorado) incompleto

( ) Pós-Graduação (Especialização/Mestrado/Doutorado) completo

\section{Tempo de serviço}
( ) 0 a 2,5 anos
( ) 2,6 a 4,9 anos
( ) 5,0 a 7,4 anos
( ) 7,5 a 10 anos
( ) mais de 10 anos de serviço

Vínculo funcional com o Cade

$\begin{array}{lll}\text { ( ) EPPGG } & \text { ( ) Analista em Tecnologia da } & \text { ( ) Apoio Administrativo } \\ & \text { Informação } \\ \text { ( ) Procurador Federal } & \begin{array}{l}\text { ( ) Servidor concursado de } \\ \text { outra carreira }\end{array} & \text { ( ) Estagiário } \\ & \text { ( ) Ocupante de cargo DAS } & \text { ( ) Outro cargo terceirizado } \\ \text { ( ) Analista Técnico- } & \text { sem vínculo }\end{array}$

( ) Agente Administrativo 
Ocupa posição de chefia? ( ) sim （ ) não

Selecione a sua lotação atual

\author{
Área finalística \\ Superintendência-Geral \\ ( ) Coordenações de cartel \\ ( ) Coordenações de AC/condutas \\ ( ) Gabinete \\ ( ) Tribunal \\ ( ) Procuradoria \\ ( ) Presidência (gabinete e \\ assessorias)
}

Área de suporte

( ) Gabinete da Diretoria Administrativa

( ) CGESP

( ) CGP

( ) CGTI

( ) CGOFL 